\title{
CLINICAL VALIDATION AND METHOD DEVELOPMENT OF THE DRAWING VERSION OF THE PRISM TEST
}

\author{
PhD Thesis
}

Zita Sándor MA

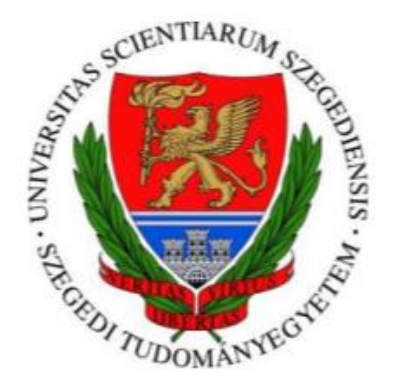

Szeged 


\title{
CLINICAL VALIDATION AND METHOD DEVELOPMENT OF THE DRAWING VERSION OF THE PRISM TEST
}

\author{
$\mathrm{PhD}$ Thesis \\ Zita Sándor MA \\ Doctoral School of Clinical Medicine \\ Faculty of Medicine \\ University of Szeged
}

Supervisor:

Prof. Márta Csabai, MA, PhD

Szeged

2021 


\section{List of publications providing the basis of the thesis:}

I. Sándor Z, Látos M, Pócza-Véger P, Havancsák R ${ }^{\dagger}$, Csabai M. The drawing version of the pictorial representation of illness and self measure. Psychology and Health. 2020; 17:1-16. IF: 2,528*

II. Sándor Z, Csabai M. A PRISM-D rajzteszt alkalmazása a daganatos betegséggel összefüggő érzelmi és kognitív reprezentációk komplex vizsgálatára. Orvosi Hetilap. 2018;59(48): 2021-2030. IF: $\mathbf{0 , 5 3}$

III. Sándor Z, Látos M, Csabai M. Észlelt társas támogatás összefüggéseinek vizsgálati lehetőségei a PRISM-D rajzteszt segítségével kórházi kezelés alatt álló súlyos betegek körében. Orvosi Hetilap. 2020;161(39): 1688-1696. IF: 0,497*

\section{List of publications related to the subject of the thesis:}

I. Látos M, Sándor Z, Kriston P, Havancsák R, Horváth Z, Paszt A, Simonka Zs, Lázár Gy, Csabai M. Associations Between a Sedentary Lifestyle and Negative Mood State and the Risk of Breast Cancer. In: Benkő Zs, Modi I, Tarkó K, editors. Leisure, Health and Well-Being: A Holistic Approach. Cham, Switzerland: Palgrave Macmillan; 2017. p. 99-114.

II. Sándor Z, Csabai M. Emlődaganatos betegek hangulati állapotának, betegséggel kapcsolatos érzelmi és kognitív reprezentációinak vizsgálata a perioperatív időszakban. In: Futó Z, editor. Tudomány és innováció a lokális és globális fejlődésért: nemzetközi tudományos konferencia előadásai. Szarvas, Magyarország: Szent István Egyetem Egyetemi Kiadó; 2015. p. 94-101.

III. Sándor Z, Csabai M. A mütét előtti szorongás előfordulása és posztoperatív fájdalommal való kapcsolata emlődaganatos betegek esetében. Kitekintés - Perspective. 2014;18(20):176-185.

IV. Sándor Z, Csabai M. Emlődaganatos betegek betegségreprezentációinak több szempontú vizsgálata. In: Koncz I, Szova I, editors. Hiteles(ebb) tudományos prezentációk II. kötet: PEME VIII. Ph.D. - Konferencia. Budapest, Magyarország: Professzorok az Európai Magyarországért Egyesület; 2014. p. 26-37. 
V. Pócza-Véger P, Havancsák R, Látos M, Kovács P, Sándor Z, Barzó P, Csabai M. Kórházi betegek betegségreprezentációinak megjelenítése a PRISM-D rajzteszt használatával. In: Kővágó, Pál; Vass Z, Vargha A, editors. II. Országos Alkalmazott Pszichológiai PhD Hallgatói Konferencia: Előadás kivonatok. Budapest, Magyarország: Károli Gáspár Református Egyetem (KGRE); 2013. URL: http://www.kre.hu/ebook/dmdocuments/ii orszagos alkalmazott pszicholo giai phd hallgatoi konferencia/chap 25.html

VI. Havancsák R, Pócza-Véger P, Látos M, Kovács P, Sándor Z, Barabás K, Csabai M. PRISM-D rajzteszt térbeli formációinak elemzése a betegségreprezentációk és a megküzdési kapacitás vizsgálatára. In: Tisljár-Szabó E, editor. XIII. Magatartástudományi Napok: Magatartástudományok a betegellátásban, Debrecen, Magyarország; 2013. p. 42-43.

VII. Havancsák R, Pócza-Véger P, Látos M, Kovács P, Sándor Z, Barabás K, Csabai M: PRISM-D rajzteszt térbeli alakzatainak kódrendszere a kórházi betegek betegségreprezentációinak vizsgálatára. In: Vargha A, editor. Kapcsolataink világa: Magyar Pszichológiai Társaság XXII. Országos Tudományos Nagygyülés: Kivonatkötet, Budapest, Magyarország: Magyar Pszichológiai Társaság; 2013. p. 264.

VIII. Sándor Z, Czinderi K, Csabai M: Betegség-reprezentációk, mütét utáni fájdalom és társas támogatás összefüggései a PRISM-D nonverbális teszten frissen operált emlődaganatos betegeknél. In: Vargha A, editor. Kapcsolataink világa: Magyar Pszichológiai Társaság XXII. Országos Tudományos Nagygyülés: Kivonatkötet, Budapest, Magyarország: Magyar Pszichológiai Társaság; 2013. p. 265.

IX. Havancsák R, Kovács P, Látos M, Sándor Z, Barabás K, Csabai M. A PRISM rajzteszt alkalmazása kórházi betegek reprezentációinak és a megküzdést segítő tényezők feltárására: Első hazai tapasztalatok. In: Vargha A, editor. A tudomány emberi arca: A Magyar Pszichológiai Társaság XXI. Országos Tudományos Nagygyülése: Kivonatkötet, Szombathely, Magyarország: Magyar Pszichológiai Társaság; 2012. p. 311.

X. Havancsák R, Kovács P, Látos M, Sándor Z, Barabás K, Csabai M. A PRISM nonverbális teszt első hazai alkalmazásának tapasztalatai kórházi osztályokon fekvő daganatos betegekkel. In: Barabás K, Kapocsi E, Pikó B, Hamvai Cs, Látos M, Bóta M, Vári-Kószó M, editors. XII. Magatartástudományi Napok: Programfüzet és absztraktok kivonata, Szeged, Magyarország: JATEPress Kiadó; 2012. p. 72. 


\section{Table of contents}

\section{ABBREVIATIONS}

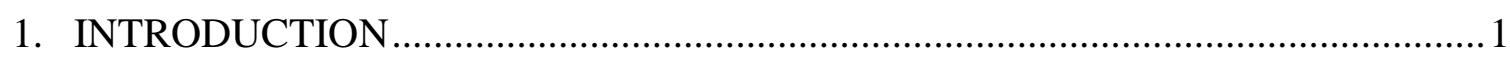

1.1. The importance of examining illness-related representations and social support.. 1

1.2. Difficulties in measuring illness-related representations and social support .........6

1.3. Advantages of nonverbal techniques ........................................................... 8

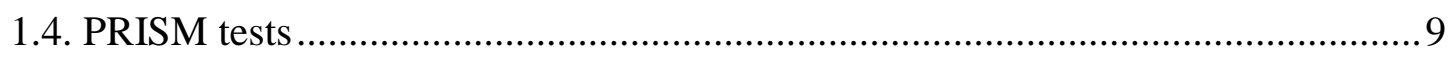

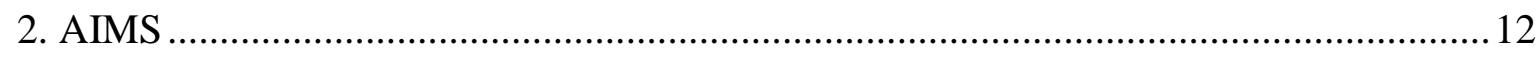

3. STUDY1: Clinical validation of the PRISM-D test.................................................. 14

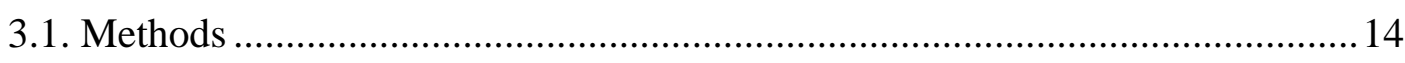

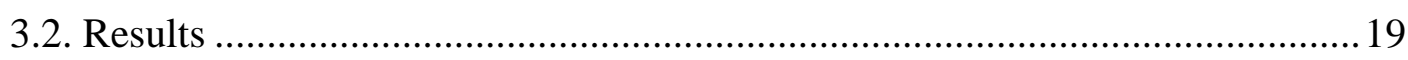

4. STUDY2: Applicability of the PRISM-D test to examine illness representations .........26

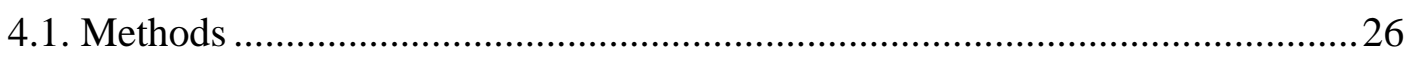

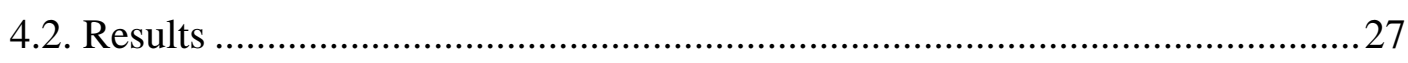

5. STUDY3: Applicability of the PRISM-D test to examine perceived social support.......32

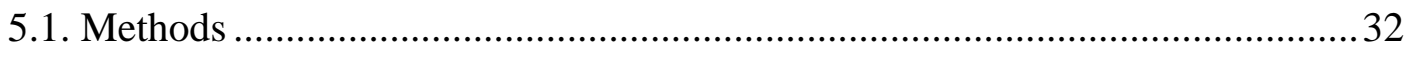

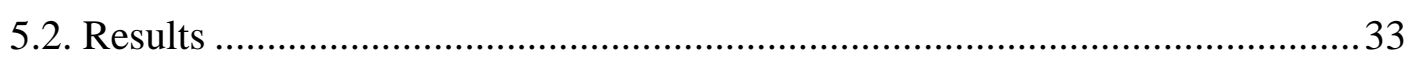

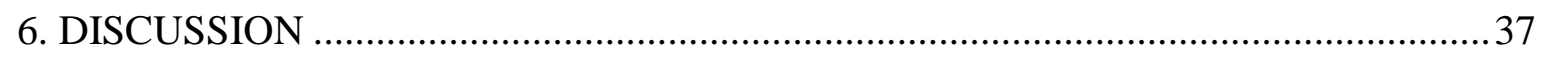

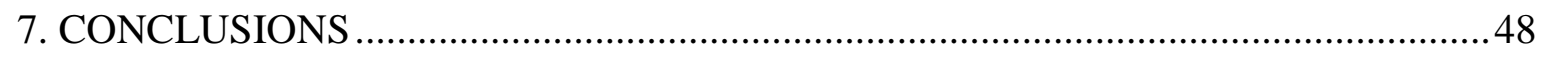

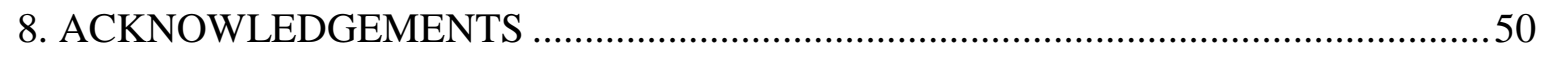

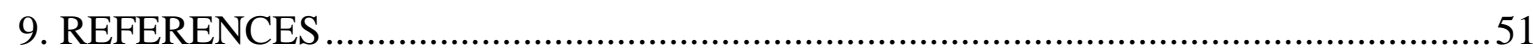

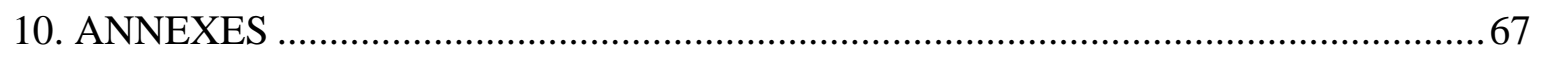




\section{ABBREVIATIONS}

BDI = Beck's Depression Inventory

IPM = Illness Perception Measure

PRISM = Pictorial Representations of Illness and Self Measure

PRISM-D = Drawing version of Pictorial Representations of Illness and Self Measure

SIS = Self-Illness Separation

STAI-S = Spielberger's State-Trait Anxiety Inventory - State Anxiety Scale

STAI-T $=$ Spielberger's State-Trait Anxiety Inventory - Trait Anxiety Scale 


\section{INTRODUCTION}

\subsection{The importance of examining illness-related representations and social support}

Examination of illness-related emotions, representations, and social support is of paramount importance in clinical practice, as research has shown that these factors are related to the mental and physical recovery of severe patients (Cameron \& Leventhal, 2003; McGregor \& Antoni, 2009; Petrie, Jago \& Devcich, 2007; Hagger \& Orbell, 2003; Pennix et al., 1998; Reblin \& Uchino, 2008; Wills \& Fegnan, 2001). A serious illness is a traumatic experience for most patients (Livneh \& Antonak, 2005), which can restructure the order of importance of factors present in a person's life, social relationships (Cassel, 2004; Stanton, Revenson \& Tennen, 2007; Rokach, 2000) and test patients' mental capacity.

Facing an illness can cause a number of reactions in an individual. One of the most common reactions is elevated distress and anxiety (Noyes, Holt \& Massil, 1998), which has been reported in 35-38\% of cancer patients (Zabora et al., 2001; Carlson et al., 2004); 14.1-27.3\% of diabetes patients (Pandit et al., 2014), 38\%-45\% of chronic renal failure (Murtagh, Addington-Hall \& Higginson, 2007). Elevated levels of distress and anxiety are problematic not only because of their negative impact on patients' quality of life (Frisch, 2005), but also negatively affect a number of processes associated with the course of the illness. On the one hand, it directly influences certain physiological processes associated with recovery, such as slowing wound healing (Broadbent et al., 2003; Marucha, Kiecolt-Glaser \& Favagehi, 1998; Kiecolt-Glaser et al., 1998), increasing experienced pain (resulting in increased analgesia, dose and demand as well as decreased exercise) (Johnston, 1988; Matthews-Ridgeway, 1981; Kehlet, 1997) and negatively affects immunological processes (Kemeny \& Gruenewald, 2000; Kiecolt-Glaser et al., 1998). On the other hand, as an indirect effect, it can negatively affect illness adaptation and coping responses (McGregor \& Antoni, 2009).

During the course of the illness, the majority of patients experience some degree of suffering, which is mostly due to the symptoms experienced, the treatments, or the clinical setting. (Krikorian \& Limonero, 2012; Cassell, 1999, 2004; Kahn \& Steeves, 1995). However, research on the subject reveals that suffering as an experience affects the whole person, not only in a physical sense, but also in a mental, social and spiritual sense (Krikorian \& Limonero, 2012; Cassell, 1999, 2004). Reducing suffering is a particularly important, complex intervention task for patient well-being (Krikorian et al., 2014). Suffering is often caused by the loss of illness 
and the possibility of it (Kahn \& Steeves 1995), which can be physical loss (body part, loss of bodily function) and non-physical loss, such as mental, social or even spiritual loss (Livneh \& Antonak, 2005; Teel, 1991).

In addition to suffering, a denial reaction often appears as a reaction to the person experiencing loss (Kreitler, 1999). Studies show that denial is very common in chronic patients (Telford, Kralik \& Koch, 2006), such as denial of diagnosis in cancer patients in 4-47\%, the denial of impact occurred in 8-70\%, denial of emotions and occurred in 18-42\% of the cases (Vos \& de Haes, 2007). According to the results of meta-analyses, denial may be beneficial in the initial and terminal stages of the illness, as it reduces the patient's level of anxiety. However, in other stages of the course of the illness, persistent denial has a distinctly negative impact, it can disrupt the process of spiritual processing of the illness and deprive the person of the opportunity to cope (Kreitler, 1999). This is because dealing with the illness and its consequences can greatly aid psychological adjustment (de Ridder et al., 2008).

In adapting to an illness as a fundamentally stressful event, it is important for individuals to highlight the positive or negative aspects of the changes associated with the illness. Highlighting the negative meaning of the illness goes hand in hand with focusing on its negative aspects, which in many cases are related to the view of the illness as an uncontrollable, unpredictable, and unchangeable agent (Evers et al., 2001). However, some patients are able to view the positive aspect of the illness, which is important because research has found a positive meaning for a fundamentally stressful event, such as a serious illness, as well as the patient's belief in recovery and illness outcome, plus more favorable representations are associated with significantly more positive physical and psychosocial health outcomes (Carver et al., 1993; Mondloch, Cole \& Frank, 2001).

How a person responds to and experiences their illness is very unique, based on, among other things, personality (e.g., neuroticism, or optimism as a personality trait), the characteristics of the illness, and cognitions related to the illness (Adler \& Matthews, 1994). This is because illness is a subjective experience for all people. During the course of the illness, based on information and experience about the illness, each patient develops a subjective perception of the illness, an illness representation combining feelings, knowledge, beliefs, and thoughts about the illness (Levethal's Self-Regualtion Theory; Leventhal, Meyer \& Nerez, 1980; Leventhal H., Leventhal E. \& Cameron, 2001; Weinman \& Petrie, 1997). This subjective illness representation is of great importance based on study results, as it is related to patients' coping 
responses and adaptation to stressors, and affects perceived well-being and life satisfaction (Krikorian et al., 2014; Petrie \& Weinman, 2012; Anagnostopoulos \& Spanea, 2005). This is because illness-related cognitions can be seen as a kind of mediator between illness and patient well-being (Evers et al., 2001). Illness perception also has an effect on illness behavior and various indicators of mental and physical recovery (Dempster, Howell \& McCorry, 2015; Weinman \& Petrie, 1997; Hagger \& Orbell, 2003). They influence, for example, adherence to treatment (Weinman \& Petrie, 1997), postoperative recovery (Juergens et al., 2009), the incidence of complications (Cherrington et al., 2004), participation in rehabilitation programs (Weinman \& Petrie, 1997), and returning to work (Petrie et al., 1996; Lacroix et al., 1991).

The subjective perception of the illness can be seen, for example, in how patients interpret their illness (Lipowski, 1970; 1983). Some view their illness as Enemy, Punishment, Weakness, Loss, while others view him as Challange, Value, Relief, or Strategy (Lipowski, 1970; 1983). Studies have shown that Challenge is the most common of the above categories of interpretation in patients with cancer (Karen et al., 1996; Lesley et al., 2003; Wallberg et al., 2003; Büssing \& Fischer, 2009) and chronic renal diseases (Caress, Luker \& Owens, 2011). Another illness interpretation category was identified as Adverse Interruption of life, which in some studies proved to be the most common illness interpretation category among chronic patients (Büssing \& Surzykiewicz, 2015) and patients with chronic pain (Büssing et al., 2010). Taking into account the research results, it is worthwhile to examine how individual patients interpret their illness, as illness interpretations can influence the choice of decision-making and coping strategies, which are important factors for recovery (Büssing \& Fischer, 2009).

Although the above results show that patients' feelings, reactions, and thoughts about the illness are paramount, it is worth noting that the illness is not present in isolation in a person's life, but is an integral part of it. The social environment around the patient also plays a key role in the reactions to the illness, in its experience and in the development of the illness behavior. This social environment, if it works properly, provides emotional and / or instrumental support, socalled functions as social support. Social support - that is, the psychosocial resources provided by significant others in a person's social environment (Kaplan, Cassel \& Gore, 1997) — has a number of positive effects on severely ill patients. Studies have shown that people with higher levels of social support are more tolerant of illness-related changes (Holahan et al., 1997; Turner-Cobb et al., 2002; Penninx et al., 1998; Stone et al., 1999), experience lower postoperative pain, and better treatment outcome is expected in their case (Stefaniak et al., 2012; Krohne \& Slangen, 2005). In general, social support has a positive effect on morbidity, 
mortality, and quality of life indicators in chronic patients (Reblin \& Uchino, 2008). However, research findings point out that favorable outcomes do not depend on the number of objectively measurable relationships or the amount of help actually provided, which are relatively easily measurable dimensions, but on social support from the patient's subjective perception (Uchino, 2004; Barrera, 2000), which is created through an individual's processes of perception, evaluation, and memory (Lakey \& Drew, 1997).

If social support works well, it acts as a kind of perceived resource in the period of coping with the illness. With the right social support, patients can receive information, help, and emotional support that can contribute to accepting the illness and developing appropriate coping responses (Uchino, Cacioppo \& Kiecolt-Glaser, 1996; Patel, Peterson \& Kimmel, 2005). Members of the social support environment also play a role in shaping the illness perception (Benyamini, Medalion \& Garfinkel, 2007; Guzman \& Nicassio, 2003). Furthermore, the way family members respond to the illness and their involvement in the treatment of the illness can greatly influence the health-protective behavior of patients and thus the outcome of the illness (Molloy, Johnston \& Witham, 2005; Cardol et al., 2005). In addition, social support people can reinforce in patients the feeling that they are important to them and worth recovery (Brummet et al., 2005), which can give patients a purpose. Social support also has a direct effect on individuals' health, on the one hand, it influences cardiovascular, endocrine, and immune processes through a direct physiological effect (Uchino, Cacioppo \& Kiecolt-Glaser, 1996). On the other hand, research results support the ability of social support to perceive and buffer illness-induced distress, thus contributing to positive outcomes through stress reduction (Theory on Stress Buffering; Cohen \& Wills, 1985; Thoits, 1982). Furthermore, as an indirect effect, social support also has a positive effect on mental health, such as reducing the risk of developing psychological distress and depression (Procidano, 1992; Sarason BR, Sarason IG \& Gurung, 1997; Lin, Ye \& Ensel, 1999; Lakey \& Cronin, 2008).

However, a serious illness and its consequences can restructure, strengthen, or even weaken social relationships (Stanton, Revenson \& Tennen, 2007). The diagnosis, treatment, and progression of the illness are a challenge for social relationships (Rokach, 2000; Spiegel, 2001). Numerous studies have shown that people with chronic illness have fewer social relationships than healthy people (Berkanovic \& Hurwicz, 1990; Arpin et al., 1990; Vogt et al., 1992). Studies show that the relationships with friends and acquaintances become limited the most, but the relationships with a partner and a child are usually not affected negatively by the illness, and may even increase or intensify (Fitzpatrick, 1988). However, in many cases, the treatment 
of the illness leads to patients experiencing either temporari or permanent social isolation and loneliness, as contact with family and friends is often limited due to either the physical symptoms of the illness or the treatment (e.g. intensive care, quarantine). In many cases, patients are forced to face the burden of their illness alone. However, experiencing social isolation and loneliness is not favorable, as according to research results it is associated with negative health outcomes (Cacioppo \& Hawkley, 2003).

Overall, a number of psychosocial factors (e.g., illness-induced feelings, reactions, illness representations, social support) play a role in the course of the illness. Research findings on the usefulness of psychosocial interventions draw attention to the short- and long-term positive benefits of correcting maladaptive reactions and representations that may occur. For example, psychological interventions to reduce increased distress have shown that immune change and improved health have been observed in cancer patients (Andersen et al., 2007). And in HIVinfected patients, stress-management interventions have improved patients' mental health and quality of life (Scott-Sheldon et al., 2008). For example, intervention studies with the goal of restructuring illness perception have shown that people with myocardial infarction have reduced illness-related anxiety (Broadbent et al., 2009), general anxiety, depression (Sararoudi et al., 2016), and were better prepared for leaving hospital and were able to return to work earlier, showed fewer angina symptoms than their control counterparts (Petrie et al., 2002).

Intervention studies to improve social support also report its positive effects (Hartmann et al., 2010; Martire et al., 2010). For example, couple-oriented interventions have a positive effect on depressive symptoms, pain, and marital functioning in patients with various chronic patients (cancer, arthritis, cardiovascular disease, chronic pain, HIV, Type 2 diabetes; Martire et al., 2010). And as a result of family-oriented interventions that improve the involvement of family members in the treatment of chronic physical patients, a positive change in the physical and mental health of patients in cardiovascular, cancer, and arthritis patients was observed (Hartmann et al., 2010).

In order to shed light on the need for intervention, it is extremely important to detect the above factors efficiently and quickly, and to screen for any maladaptive reactions that may occur. However, because feelings and thoughts about illness and attitudes toward social relationships are highly subjective, difficult to put into words, measuring these factors is not an easy task. In addition, the special characteristics of the hospital environment also require special tools. 


\subsection{Difficulties in measuring illness-related representations and social support}

There are now a number of generic or disease-specific tests or scales available to measure illness impact, perceptions, beliefs, representations and social support (Shumaker \& Naughton, 1995; Weinman et al., 1996; Horne, Weinman, \& Hankins, 1999; Wills \& Shinar, 2000). The Illness Perception Questionnaire (IPQ; Weinmann et al., 1996) or variants thereof (e.g., IPQ-R; MossMorris et al., 2002; B-IPQ; Broadbent et al., 2006) is most commonly used to measure illness perception. The Illness Cognition Questionnaire (ICQ; Evers et al., 2001; Lauwerier et al., 2010) is suitable for assessing illness-related cognitions, and the Interpretation of Illness Questionnaire (IIQ; Büssing \& Fischer, 2009) is suitable for detecting illness interpretations.

There are also a number of scales for measuring social support, most of which measure multiple dimensions, such as The Multidimensional Scale of Perceived Social Support (Zimet et al., 1988; 1990), the Norbeck Social Support Questionnaire (NSSQ; Norbeck, Lindsey \& Carrieri 1981, 1983; Gigliotti, 2002), the Close Persons Questionnaire (Stansfeld \& Marmot, 1992), or the Social Support Questionnaire for Transactions (SSQT; Suurmeijer et al., 1995). Specifically measures the perceived social support the Social Support Questionnaire, (SSQ; Sarason et al., 1983), and an abbreviated version thereof (Brief SSQ; Siegert, Patten \& Walkey, 1987).

However, most of these, to help with the accuracy of the measurement, are quite long, containing a number of items that usually need to be evaluated on a multi-level scale. In addition, most of these tests are restrictive in measuring illness-related experiences and perceptions, which in many cases would require deeper exploration. (Cheung, Saini \& Smith, 2016). In order to be able to filter out the factors that are important for recovery, the maladaptive reactions that may appear, it is necessary to use several measuring devices at the same time.

Considering the specifics of the hospital environment and the recovery process, practical experience shows that completing the numerous paper-pencil tests can be burdensome for seriously ill patients. In addition, they are too time-consuming in terms of daily practice, and the validity of the measurement also depends to a large extent on the verbal skills of the patients (Büchi \& Sensky, 1999). Therefore, it would be necessary to use a measuring device that could quickly and simultaneously measure several mental factors important for recovery in a way that is not burdensome for patients.

Measurement is further complicated by the fact that adaptation to the illness is a non-linear process, depending on the nature and course of the illness and the characteristics of the patient, 
and it may be stuck and reversed (Stanton, Revenson \& Tennen, 2007). Along this line, patients' levels of anxiety and distress may show large changes during the course of the illness (Fallowfield et al., 1994). The illness perception can also undergo significant changes during the illness, as it is influenced by personal experiences and experiences of the illness (symptoms, examinations, treatement etc.) as well as information from the social environment (family, friends, medical staff) (Anagnostopoulus \& Spanea, 2005). In addition, during the course of the illness, social relationships may be transformed, some relationships may be strengthened, while others may be eroded by illness (Alferi et al., 2001). Therefore, when examining the above factors, it is advisable to use a measuring device that can be repeated even at short intervals, and can be applicable again and again without excessive strain on the patient, in order to be able to detect the possible changes in the condition.

Another special aggravating factor in measuring mental factors associated with illness is that illness is often needed deeper and more personalized understanding due to a subjective experience and the uniqueness of related reactions and cognitions (Cheung, Saini, \& Smith, 2016). Moreover, the illness is not present in isolation in a person's life, but is an integral part of it, and can also affect the subjective importance of factors that play a role in a person's life. It is important to explore the impact of the illness on a person's life, its embeddedness in life history, social and physical environment. Furthermore, it is advisable to assess the resources supporting recovery that are present in one's environment (eg. social support, physical or mental health-protecting habits, and activities that are sources of experiencing joy or success), or presence of factors that aggravate recovery (eg. relational conflicts, experiences of loss, and strong negative emotions). However, traditional paper-pencil methods are not suitable for exploring the above factors.

This is why several studies have used interview techniques to examine illness-related cognitions, emotional and cognitive representations, and illness burden, mostly freely, using interviews compiled for research profile (Zhang et al., 2014; Koenigsmann et al., 2006; Dong et al., 2016). In addition, there are special interview methods that have been specifically developed to measure a particular psychosocial dimension, such as the McGill Illness Narrative Interview (MINI; Groleau, Young \& Kirmayer; 2006) for assessing narratives related to illness, The Schema Assessment Instrument (SAI; Lacroix, 1991), which explores illness patterns, or the Self-Evaluation and Social Support Schedule for Measuring Social Support (SESS; Tjemsland et al., 1994) and the Mannheim Interview on Social Support (MISS; Veiel, 1999), which ones explore social support. In addition, there are disease-specific interviews, such as 
the Personal Models of Diabetes Interview, which explore the views of diabetic patients (Hampson, Glasgow, \& Toobert, 1990).

However, verbalizing the feelings and thoughts about illness and the attitudes towards social relationships is not an easy task. In addition, certain components of feelings and thoughts about the illness are not made conscious, making them difficult to explore by the interview techniques (Cheung, Saini, \& Smith, 2016). Furthermore, the method, due to its time-consuming nature, is difficult to always adapt to clinical practice and can only be used in well-verbalized patients, which is not provided in certain treatment situations due to the nature of the illness or its treatment (Higginson \& Carr, 2001).

\subsection{Advantages of nonverbal techniques}

Published data prove that nonverbal techniques can be successfully applied to severe patients with serious medical conditions. Compared to verbal techniques (questionnaire, paper-pencil tests, interview), they require less energy input from patients, yet they can be used to gather a wide range of information (Broadbent et al., 2006). A further advantage is that they are also suitable for the study of less conscious feelings and cognitions (Cheung, Saini, \& Smith, 2016).

The most commonly used nonverbal techniques are drawing tests. Traditional drawing tests (e.g., draw their illness or damaged organ, draw their body before or after disease, or currently after treatment) can reveal individual experiences with the illness and its treatment, and subjective, idiosyncratic perception of the illness (Tiemensma et al., 2012; Tiemensma et al., 2015; Kaptein \& Broadbent, 2007). In recent years, the method has been used successfully in several studies of illness perception in various somatic patients, such as: myocardial infarction (Broadbent et al., 2004), heart failure (Reynolds et al., 2007), systemic lupus erythematosus Cushing's syndrome (Tiemensma et al., 2012), emergency embolization in postpartum hemorrhage (van Stralen et al., 2010), vestibular schwannoma (Kaptein et al., 2011), headache (Broadbent et al., 2009).

Based on some study results, drawings were associated with indicators of health status and improved current understanding of the patient's perspective (Tiemensma et al., 2015). Based on research experience, the characteristics of the drawings are related to clinical and psychological markers of health status. In a study by Broadbent et al., for example, on heart drawings made by patients who underwent myocardial infarction, the displayed damage 
predicted recovery with greater confidence than traditional medical indicators (Broadbent et al., 2004). In their subsequent follow-up study, they found that changes in the size of patients' heart drawings were associated with higher cardiac anxiety, health care use, and activity restriction (Broadbent et al., 2006). A similar study also found an association between the size of heart drawings in individuals with health faliure and health-specific anxiety (Reynolds et al., 2007).

Similar results have been found by Hungarian researchers in the study of kidney transplant patients (Látos et al., 2012). Their results showed that patients experiencing a higher degree of anxiety drew their transplanted kidneys significantly larger on the drawing test. Furthermore, a meta-analysis combining research experience on the topic also found that the size of the illness depicted in the drawings is consistently associated with negative illness perception (Broadbent et al., 2019).

Drawing tests have promising opportunities for utilization for patients, researchers as well as health care professionals (Tiemensma et al., 2015). Experience has shown that drawing tests can lead to richer data collection. It has been observed that drawings can illustrate patients' notions in a more uncensored, concrete, and specific way than words (Broadbent et al., 2006). In addition, drawing has a number of benefits for patients. It can help them share emotions, experiences, and thoughts about the illness and help them better understand themselves (Cheung, Saini \& Smith, 2016). However, the fact that drawing ability may influence the interpretation of test results could be a disadvantageous trait of these tests (Tiemensma et al., 2015).

\subsection{PRISM tests}

A novel tool for nonverbal techniques in somatic patients is the Pictorial Representation of Illness and Self Meausre (PRISM) tests. The original version of the test (Büchi \& Sensky, 1999) aims to assess the perceived burden of suffering due to their illnesses among somatic ill patients using a simple, easy-to-understand visual method. However, modifications of the test also allow the measurement of a great deal of other dimensions.

In the original test, the patients are given an $\mathrm{A} / 4$ white metal board with a $7 \mathrm{~cm}$ diameter yellow circle in the lower right corner. According to the instruction, the white metal board symbolizes the patient's current life situation and the yellow circle symbolizes the patient's self. During the test recording, the patient is given a $5 \mathrm{~cm}$ diameter red magnetic disk that symbolizes the 
person's illness and this should be placed on the metal board according to how important the illness is in the person's life at the moment. In the test, the distance between the self and the disk that symbolizes the illness (Self-Illness Separation, SIS) refers to the suffering caused by the illness burden. Small distance from the self indicates a great deal of suffering, and a greater distance indicates a lower degree of it (Büchi \& Sensky, 1999). According to the results of Peter et al. (2016), it is also appropriate to examine the spatial position of the illness disk relative to the self circle (illness circle inside, overlapping or outside relative to the self circle), as these spatial positions are significantly related to depression and the level of quality of life.

A modified version of the test, PRISM-R1, is not only suitable for assessing illness suffering, but also for examining patients' illness perception (Reimus et al., 2007). For PRISM-R1, patients can choose from 3 disk of illness symbolization (smaller than a circle representing a self, a circle larger than a self, and a circle of the same size). The results show that the size of the disk symbolizing the illness refers to Illness Perception Measure (IPM).

Another version of the test, PRISM +, allows you to display factors other than the illness that are important to the patient, such as family, hobbies, work, friends using different discs (usually discs of the same size but different colors) (Büchi \& Sensky, 1998; 1999). In this way, we can explore the context of the illness, the resources of the patient, as well as the relationship between the illness and other important factors for the patient. The PRISM + test has been used in several studies, but in most cases the disks symbolized pre-defined factors. For example, Kassarjdian et al. (2008) in their study measured pain, partner, family, work, and recreational activities in their patients with chronic non-cancer pain using the PRISM + test. Gielissen et al. (2013) measured the fatigue of cancer patients using a magnetic disk for this purpose.

To eliminate the special equipment requirements of the PRISM test (magnetic board and disks), a self-administered version of the test was also developed (Rumpf, Lontz \& Uesseler, 2004), which proved to be reliable and well-suited. However, this version also only measures the impact of the illness on the person and their place in their life. However, in our opinion, the use as a paper-pencil method has additional application possibilities.

The PRISM test has been successfully validated in several patient groups and has been shown to be reliable in various chronic patients such as breast cancer, long-term cancer surivors, rehumatoid arthritis, chronic obstructive pulmonary disease, diabetes mellitus, systematic lupus erythematosus, chronic pain patients or dermatological pain patients and dermatologists (Büchi \& Sensky, 1999; Büchi et al., 2000; Büchi et al., 2002; Klis et al., 2008; Streffer et al., 2009; 
Lehmann et al., 2011; Kassardjian et al., 2008; Wouters et al., 2008; Mühleisen et al., 2009). Studies have shown a consistent negative correlation between Self-Illness Separation (SIS) and depression (Büchi et al., 1998; Büchi et al., 2002; Rumpf, Lontz \& Uesseler, 2004; Klis et al., 2008; Büchi et al., 2009; Wittmann, Schnyder \& Büchi, 2012; Lima-Verde et al., 2013; Gielissen et al., 2013; Meyer et al., 2014), anxiety / perceived stress (Klis et al., 2008; Krikorian et al., 2013), experienced pain (Büchi et al., 1998; Büchi et al., 2002; Kassardjian et al., 2008; Streffer et al., 2009), disease-specific and overall quality of life (Büchi et al., 2000; Rumpf, Lontz \& Uesseler, 2004; Mühleisen et al., 2009; Lehmann et al., 2011; Meyer et al., 2014). The Illness Perception Mesure, in turn, is significantly correlated with wellbeing (Reimus et al., 2007).

Research experience with the PRISM test shows that it is suitable as a visual method for gathering fast yet personally salient information. An important advantage is that it provides both qualitative and quantitative data. Research suggests that the test can be used well in individual and group psychological interventions to assess attitudes about illness and to assist in therapeutic decision-making (Sensky \& Büchi; 2016). 


\section{AIMS}

The doctoral dissertation presents the clinical validation and method development process of the PRISM-D test method as well as its possibilities of application. The aim of the multi-stage research is to further develop the PRISM test, a measurement tool used internationally in clinical practice and research. With this method development, the research joins the method development process of the PRISM test, which has been going on for more than 20 years.

Our method development processes have been going on since 2012 in a research group under direction of Prof. Dr. Márta Csabai. The first publication demonstrating the method of this test version was in 2013, when the characteristics of the new method were presented (Havancsák, Pócza-Véger, Csabai; 2013). Since then, several conference presentations and publications have been produced about our main results and the experiences of the clinical application of the test.

The aim of our research group was to develop a measuring device that combines the advantages of previous PRISM tests and provides more differentiated information, but at the same time requires less equipment. Our goal was to develop a measurement tool that can be easily and quickly used to examine the subjective significance and impact of physical illness, and to explore factors present in a person's social and physical environment that potentially support or even impede recovery. In a way this fits the clinical environment and does not burden serious patients.

During the development of the method, we relied on research related to previous versions of the PRISM tests, according to which the test is suitable for examining illness suffering, illness burden, illness perception and important factors present in patient's current living environment (see section 1.4.). We also relied on research on projective drawing tests in somatic patients, which have shown that projective drawing tests are suitable for exploring illness-related beliefs, identifying emotions that were not made conscious previously, and providing much richer information than traditional paper-and-pencil tests (Cheung, Saini \& Smith, 2016; Tiemesnma et al., 2015; see section 1.3.).

The main goal of this doctoral dissertation was - based on the previous findings of our research groups, as a follow-up to the PRISM-D method development process - to carry out the clinical validation of the PRISM-D test. In addition, another goal was to demonstrate the comprehensive applications of this test in the clinical practice, with particular regard to the investigation of the 
patient's illness related emotional and cognitive representations and the social support of the patients.

In connection with the doctoral research, I formulated the following goals:

AIM1: The number one goal of the research was to investigate the applicability and the clinical validaty of the modified test among a wide, non-disease-specific population of somatic patients under active hospital treatment. The aim was to explore whether the drawing test version provides additional information compared to previous PRISM tests, and whether test participants take advantage of the freedom of the visualization. In addition, the aim was to examine whether the modified test retains the benefits of previous versions, and whether we obtain results consistent with previous research in terms of external validity. Furthermore, the aim was to investigate whether there is a correlation between some of the features displayed on the PRISM-D test and the level of anxiety and depression, which is important due to its applicability in clinical practice. (STUDY1)

AIM2: Another goal was to investigate the ways in which the PRISM-D test can measure illness-related representations. This is because the study of illness representations is a particularly important task, as research has shown that they can influence the recovery process in many ways (see section 1.1), so exploring them is of paramount importance during the recovery process. The aim of the research was to present how the PRISM-D test provides quantitative and qualitative information about patients' illness-related emotional and cognitive representations, detailing the possibilities of analyzing data from the PRISM-D test post-test using an example of a cancer patient population. (STUDY2)

AIM3: The aim was to investigate in more detail whether the PRISM-D test is suitable for examining perceived social support in somatic patients undergoing active hospital treatment. According to the research results, social support is a particularly important factor in the process of recovery from serious illnesses, as it is related to a number of factors influencing physical condition (see section 1.1.). Therefore, the examination of these factors is an important task. Another research goal was to examine whether the measure is suitable for exploring perceived social isolation and assessing the subjective importance of social support persons. Another aim was to examine the relationship between the characteristics of social support displayed on the test and the level of illness perception, anxiety and depression. (STUDY 3) 


\section{STUDY1: Clinical validation of the PRISM-D test}

\subsection{Methods}

\subsubsection{Participants}

The study involved 500 patients diagnosed with somatic disease under active hospital treatment. Since the goal was to develop a non-disease-specific measurement tool, participants were selected from several disease groups in the sample. Participants were selected from the following disease groups: cancer patients $(35.6 \%)$, patients with lumbar degenerative disc disease $(31 \%)$, patients with chronic renal insufficiency (19.2\%), gastro-intestinal disease patients (7\%) and other hospital inpatients (7.2\%). Of the individuals included in the sample, $44.4 \%$ were male and $55.6 \%$ were female. The mean age of the participants in the sample was 51.9 years $(\mathrm{SD}=16.06)$.

The criteria for inclusion in the sample were: voluntary agreement to participate in, being able to participate in a test (due to their illness condition), diagnosis of the following diseases: cancer, chronic renal insufficiency, gastro-intestinal disease, lumbar degenerative disc disease (excluding pilot research, where this condition did not have to be met), and being under active hospital treatment. Individuals who met the criteria were randomly selected in the sample (convenience sampling method).

The data collection consisted of three stages. As a first step, a pilot study examined whether test participants could interpret the instructions and tasks of the test. To this end, the PRISM-D test was tried on a random sample of 25 hospital inpatients. A structured interview was used to assess whether participants were able to properly interpret and perform the test recording. Since all participants understood the instructions, the second step in the research was to take a larger sample of the PRISM-D test from the following patient groups: cancer, chronic renal insufficiency, gastro-intestinal disease, lumbar degenerative disc disease. The target sample was 300 people and the number of tests to be evaluated was 278. As a third step in data collection, to examine the convergent validity, the PRISM-D test, Spielberger's State and Trait Anxiety Inventory (STAI), and Beck's Depression Inventory (BDI) were used. Participants were composed of the following disease groups: cancer, chronic renal insufficiency, gastrointestinal disease. As the total number of items targeted for the total research was 500, this phase of the research was completed after the inclusion of 197 evaluable tests. 
Data collection took place in the departments of the following clinical centers / hospitals: SzentGyörgyi Albert Clinical Center, University of Szeged (Szeged); the National Institute of Oncology (Budapest); and Pándy Kálmán Member Hospital of the Békés County Central Hospital (Gyula). The data collection was carried out with the support of the above institutions. Participants volunteered for the study and signed an informed consent form prior to data collection.

Data collection was conducted by specialists with a Bsc and MA degree in psychology. Prior to the inclusion of PRISM-D tests, demographic (age, gender) and disease-specific data (disease type) were collected. The recording of the drawing test, including a post-test, lasted 5-15 minutes. In the third phase of data collection, after taking the PRISM-D test, the participants also completed the STAI and BDI tests.

\subsubsection{Measures}

\section{PRISM-D test}

Recording a PRISM-D drawing test consists of several steps. The participants are first given a pre-printed A4-size sheet of paper with a yellow circle that is $7 \mathrm{~cm}$ in diameter in the lower right corner (Figure 1.). According to the test recording instruction (Figure 2,), the white sheet symbolizes the person's current living environment and the yellow circle symbolizes the person's self. On this sheet, participants should draw with a red felt-tip pen in a circle of any size and location to symbolize their illness.

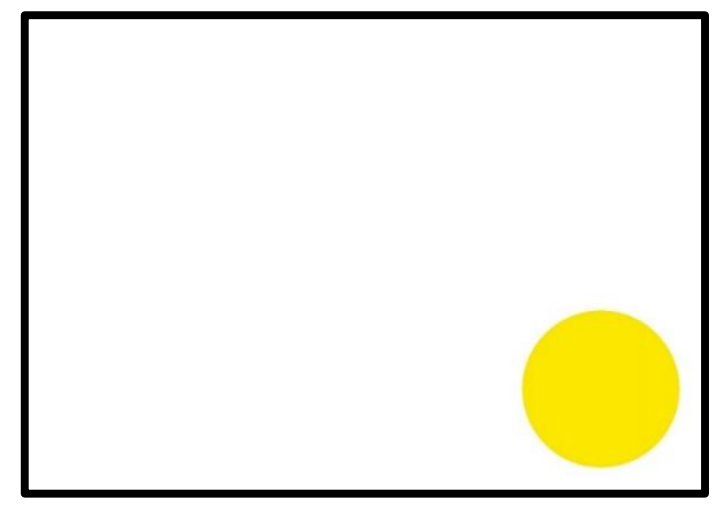

Figure 1. A blank PRISM-D test. The circle in the lower right corner symbolizes the self, and the blank area symbolizes the person's living environment. 


\section{PRISM-D instructions}

Dear Sir/Madame,

We would like to gain a better understanding about how your illness affects your current life. Here is a white sheet of paper (When the participant receives the paper, the yellow circle must be in the lower right corner from his/her perspective).

Imagine this paper represents your life, and the yellow circle on it represents you. Please draw another circle for your illness with this red felt marker in a position where you think it bests fits compared to yourself (The test leader hands a red felt marker to the participant, and after the participant has drawn the circle representing the illness, the test leader puts away the red felt marker).

In case of faltering, give further instructions if needed: think about how the illness influences your life and how hard you feel about the symptoms. Now, please draw all the important areas of your life you can think of (if the participant asks what you mean, you may note examples such as family, work, hobbies, or anything that could be of particular importance for the patient). These are the colors you can use (The test leader gives the felt markers for the patient's disposal). Please similarly draw circles or disks to represent factors that are relevant to you.

In case of faltering, give further instructions: think about what other things you have not drawn yet that are important to you.

Post-test: What does this circle represent in your life? (During the post-test, the test leader notes the meaning of each circle).

Figure 2: PRISM-D test instructions for test leaders

As a second step in the test recording, participants have the opportunity to visualize the factors that are important to them in their current living environment using felt-tip pens of different colors (yellow, orange, pink, purple, blue, green, brown, black) of any size, color, and number of circles. In this test version, the participants were not given any instructions or suggestions for what factors they should draw. They could freely decide on which factors to represent in the test, without any limitations to the number of the factors.

During the test recording, the test leader literally records the drawing order and color of the drawn circles on a dedicated data sheet (Annex 1). Then, during the post-test, the test leader asks what each circle indicates. The answers are recorded verbatim on the data sheet by the researchers. Any special reactions that may occur, e.g. crying, jamming, irritability, confusion, 
indicated in a separate section of the data sheet. (Note: Post-test responses are subject to quantitative analysis, which was not part of the present study.)

The data obtained in the test can be subjected to multi-criteria quantitative and qualitative analysis. As with the original PRISM tests (Büchy \& Sensky, 1999), the SIS index (Self-Illness Separation) can be calculated based on the distance between the centers of the self circle and illness circle. Based on Reimus et al. (2007) study, the area of the illness circle reflects the illness perception (Illness Perception Measure, IPM). Given that the PRISM-D test is a drawing test, the size of the drawn circles can vary. We calculated the area of the illness circles by measuring their radius, thus getting the values of IPM.

In the case of freely drawn circles, it is advisable to categorize the answers according to their meaning content. In the present study, the coding of responses based on the meaning of the responses was performed by two independent coders. If there was no match in the codes, a third encoder was included. Similar to the PRISM+ tests (Büchi \& Sensky, 1998; 1999), we can also calculate the distance of the freely drawn circles from the self area (if several circles belonged to one category, the areas of each circle were added together). Furthermore, the sizes of the factors examined as well, by calculating their area (if several circles belonged to one category, the average distance of the circles from the self was calculated).

\section{STAI}

Patients' levels of anxiety were assessed using the Spielberger's State-Trait Anxiety Inventory (Spileberger, Gorsuch \& Lushene, 1970; Sipos K \& Sipos M, 1978). The measure consists of two scales, each containing 20-20 items to be rated on a 1 to 4 Likert scale. The so-called Trait Anxiety Scale (STAI-T), measures the general level of anxiety characteristic of a person whereas the so-called State Anxiety Scale (STAI-S) is the level of anxiety one is currently experiencing. The total score on the scales can range from 20 to 80 , where a higher score indicates a higher level of anxiety experienced. The reliability of the questionnaire is adequate $($ Cronbach alpha $=.77)$. 


\section{BDI}

Participants' depression levels were measured using a 21-item version of the Beck's Depression Inventory (Beck et al., 1960; Ritcher et al., 1998; Rózsa, Szádóczky \& Füredi, 2001). For each item in the inventory, the subject must decide from 4 statements that have been characteristic of them in the last weeks or days. During the evaluation of the test, the answers should be scored from 0 to 3 . The total score for the full scale can tally between 0 and 84 . A higher score indicates the presence of increased depressive symptoms. The internal validity of the scale is adequate.

\subsubsection{Data analysis}

During the pilot research, the responses to the structured interview were subjected to qualitative analysis. Quantitative data obtained during the research were analyzed with SPSS 21. The parameters measured were the distance between the self and the factors drawn on the PRISMD test (in centimeters), as well as the area of these factors (in square centimeters). Descriptive statistics were calculated from the data, such as percentages, means, standard deviations, and median. For the STAI and BDI tests, the mean and standard deviation of the total scores of the scales were calculated.

During the data analysis, Student's t-test was used to examine the gender differences in illnesscircle characteristics represented on the PRISM test, and Pearson's correlation test was used to examine the associations with age. To examine the convergent validity of the PRISM-D test, the relationship between SIS and the STAI-S, STAI-T, and BDI scales, as well as the IPM and the STAI-S, STAI-T, and BDI scales, the Pearson's correlation test was used. In addition, comparative analysis was conducted using a student's t-test and chi-squared test between the total scores of the BDI, STAI-S, and STAI-T scales and the factors drawn on the PRISM-D test. For each statistical procedure, the assumptions were tested and they were met in case of the results presented in the paper. 


\subsection{Results}

\subsubsection{Pilot research}

As a first step in the research, in a pilot study, the PRISM-D test and structured interviews were used with 25 hospital in-patients to test the applicability of the new method. Based on the responses to the structured interview, it was found that each patient was able to comprehend and execute the tasks.

\subsubsection{PRISM-D task's characteristics}

\section{Illness circle}

The SIS was $11.19 \mathrm{~cm}$, which implies high level of suffering from the illness burden, as according to the literature on the original PRISM test (Büchi et al., 1998; Büchi \& Sensky, 1999), a smaller SIS indicates a considerable suffering. However, since variance was very high $(\mathrm{SD}=7.53)$, it can be said that the illness burden indicated high individual variability within the sample. The smallest measured value was $0 \mathrm{~cm}$ (in this case, the illness circle was within the self circle, the centers of the circles overlapped), and the largest was $29.9 \mathrm{~cm}$.

The relative position of the self circle and the illness circle, the large and small SIS, is demonstrated in Figure 3.

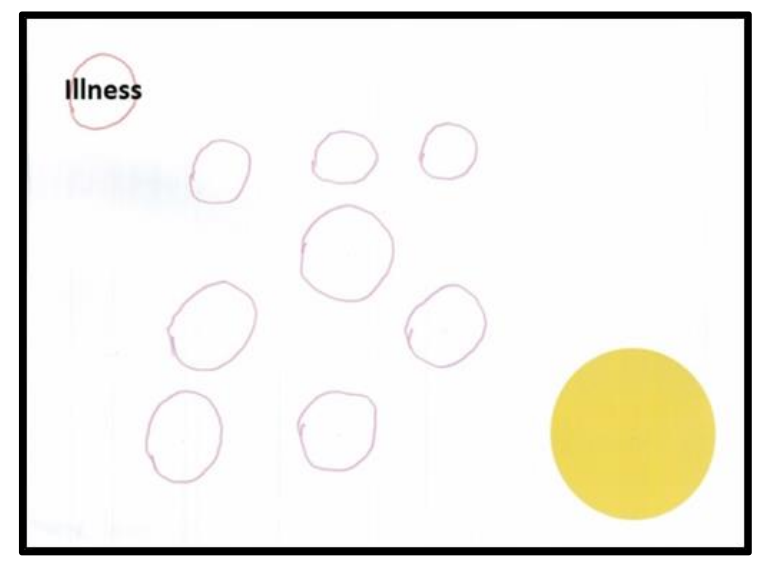

Figure 3a: PRISM-D drawing from a 75-yearold woman with lumbar degenerative disc disease. The illness circle is separated, and SIS is high.

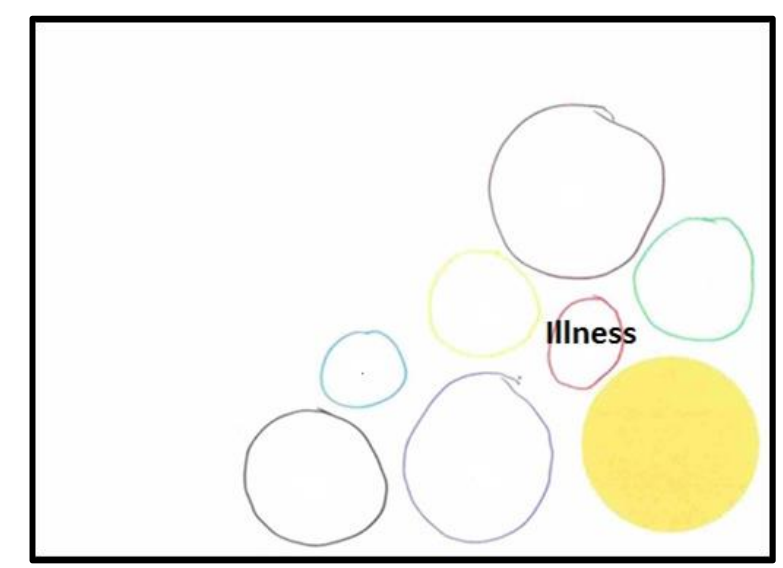

Figure 3b: PRISM-D drawing from a 25-yearold man with melanoma malignum. The illness circle isnseparated, and SIS is small 
Regarding the position of the illness circle in relation to the self circle, it can be said that $79.6 \%$ of the participants drew their illness outside the self circle (Figure 3a, 3b). In $4.19 \%$ of the cases where the illness was separated from the self, the two circles were touching. Only $16.06 \%$ of participants drew their illness within the self circle, or in the case of an illness circle larger than the self circle, to completely overlap with the self, which may indicate a higher degree of illness burden (Figure $4 \mathrm{a}$ ). Overall $4.34 \%$ of the participants drew partial overlap with the self circle (Figure 4b).

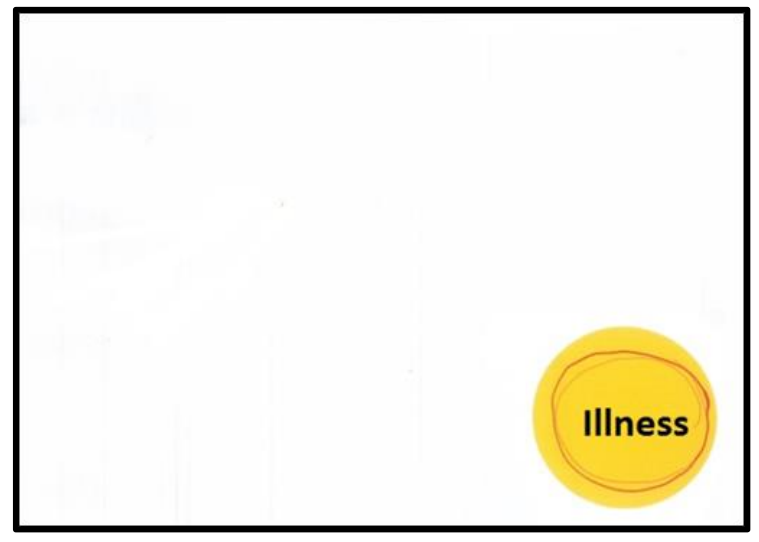

Figure 4a: PRISM-D drawing from a 31-yearold woman with breast cancer. The illness circle is within the self.

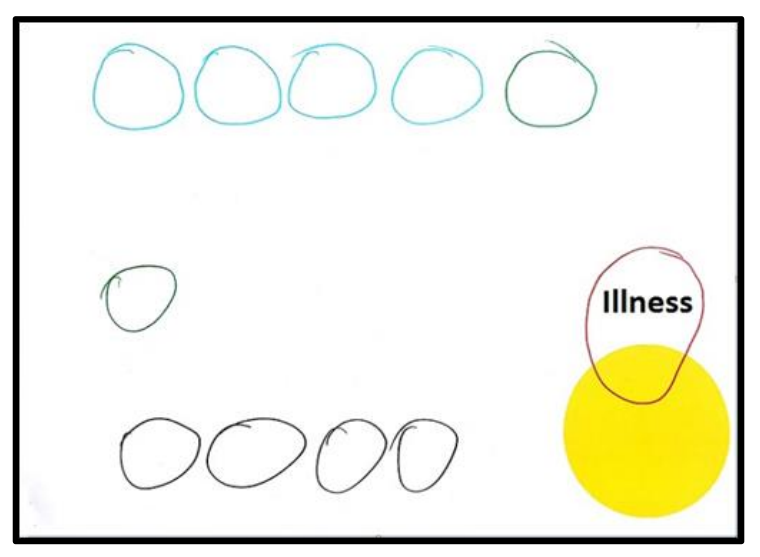

Figure 4b: PRISM-D drawing from a 50-yearold man with chronic renal failure. The illness circle partially overlaps with the self

The size of the illness circle drawn also showed great individual variability. The IPM was on average $23.09 \mathrm{~cm}^{2}$, which is smaller than the size of the displayed self (note: due to freehand drawing, in many cases the circles took an irregular shape. excluded). The value of size deviation was very high, 43.64, suggesting that participants displayed their illness as very different in size, suggesting a different illness perception. The area of the smallest circle of illness was $0.1 \mathrm{~cm}^{2}$, in which case the illness was in fact represented not by a circle but by a tiny point. The largest illness circle was $415.27 \mathrm{~cm}^{2}$, which filled the sheet almost completely. Based on the size of the illness circles relative to the self circle, it can be said that $78.4 \%$ of them were smaller than the size of the self circle, $10.3 \%$ were almost the same size, and $11.3 \%$ were larger than the self circle. Overall, $92.05 \%$ of the illness circles were not colored and $7.95 \%$ were.

No gender differences were observed for SIS and IPM (Student's t-test, $\mathrm{p}>$.05). Furthermore, there was no significant correlation between SIS and age and between IPM and age (Pearson's correlation coefficients $\mathrm{p}>.05$ ). 


\section{Other drawn circles}

After drawing the illness circle, participants could freely draw the important factors in their current living environment using circles of any size, location, color, and number. The meaning of each circle was literally recorded by the test leader after drawing. Participants scored an average of 5.81 circles on the test, including the illness circle. However, there were large individual differences in the amount of circles displayed, as indicated by a standard deviation of 2.86. In sum, $1 \%$ of participants did not display any important factors other than the illness in their current living environment. The most circles drawn were 23 pieces. The number of circles displayed may indicate the complexity or emptiness of the living environment. However, seemingly empty living environment can also indicate a narrowed focus on the illness or its treatment.

The drawn circles were categorized based on their meaning during the analysis (using two independent encoders). According to our results, the following response categories appeared: family members (family, partner, relatives) and friends (friends, colleagues, acquaintances, neighbors). Together from these two categories, we created a main category social support. Other categories: work (job and work activities) hobbies (any recreational activity was classified as a hobby), negative stressors (factors affecting the person unpleasantly or negatively, such as negative emotions, experiences of loss, and relationship conflicts), health (health and related meanings), recovery (healing, recovery and related meanings), and treatment-related factors (meanings related to the treatment of illness and hospital environment). From the categories health, recovery and treatment-related factors a so-called main category illness-related factors main category was created.

All in all, 26.93\% of all circles displayed could not be categorized due to their uniqueness and low occurrence. Some examples of circles with unique meaning (less than 5\% prevalence each) are: financial security, home, nature, religion / God, deceased loved ones, former spouses, a variety of feelings, love, and freedom. Although these responses are not suitable for statistical analysis, they can provide useful information to professionals in diagnostic proceed, individual case management and effective psychological intervention work.

In terms of frequency, the most frequently displayed response category was social support. It was drawn by $93.4 \%$ of the participants, the majority (65.7\%) using multiple circles. The second most common response category was work (27.9\%), followed by hobby $(22.5 \%) .15 \%$ of respondents drew health, $9.1 \%$ drew the recovery, and $7.5 \%$ drew treatement realted factors. $5.9 \%$ of them displayed a negative stressor. 
The frequency of drawing the circles drawn on the PRISM-D test, as well as data on their distance and area from the self circle, are summarized in Table 1.

\begin{tabular}{|l|l|l|l|l|l|l|l|l|l|}
\hline \multirow{2}{*}{} & Illness & $\begin{array}{l}\text { Social } \\
\text { support }\end{array}$ & Work & Hobby & Health & Recovery & $\begin{array}{l}\text { Treatment } \\
\text { related } \\
\text { factors }\end{array}$ & $\begin{array}{l}\text { Negative } \\
\text { stressors }\end{array}$ \\
\hline $\begin{array}{l}\text { Drawn by } \\
(\% \text { of participants })\end{array}$ & 10.0 & 93.4 & 27.9 & 22.5 & 15.0 & 9.1 & 7.5 & 5.9 \\
\hline \multirow{2}{*}{$\begin{array}{l}\text { Distance } \\
\text { from } \\
\text { self }(\mathrm{cm})\end{array}$} & mean & 11.19 & 11.06 & 11.70 & 11.03 & 11.15 & 11.65 & 14.22 & 15.36 \\
\cline { 2 - 10 } & median & 11.00 & 11.40 & 11.55 & 9.50 & 11.10 & 12.05 & 14.72 & 15.15 \\
\cline { 2 - 10 } & SD & 7.53 & 5.58 & 5.45 & 6.08 & 6.04 & 5.77 & 7.16 & 7.46 \\
\cline { 2 - 10 } & max. & .00 & .00 & .00 & .78 & .00 & .00 & .00 & .00 \\
\hline \multirow{2}{*}{$\begin{array}{l}\text { Area } \\
\left(\mathrm{cm}{ }^{2}\right)\end{array}$} & mean & 29.90 & 31.30 & 25.00 & 24.20 & 24.70 & 22.50 & 28.00 & 28.00 \\
\cline { 2 - 10 } & median & 9.39 & 19.04 & 9.07 & 8.03 & 8.55 & 9.05 & 4.52 & 9.34 \\
\cline { 2 - 10 } & SD & 43.64 & 87.75 & 48.10 & 42.82 & 8.26 & 64.28 & 11.53 & 23.81 \\
\cline { 2 - 10 } & min. & .01 & .00 & .12 & .06 & .28 & .50 & .03 & .03 \\
\cline { 2 - 9 } & max. & 415.27 & 1205.76 & 333.12 & 393.88 & 609.16 & 379.94 & 4.69 & 102.02 \\
\hline
\end{tabular}

Table 1: Descriptive statistics of the circles represented on the PRISM-D test. Note: percentage of participants representing a given factor (category); mean, median, SD, minimum, maximum of the distance between the self and represented factors (category); mean, median, SD, minimum, maximum of the area of factors (category).

\subsubsection{Convergent Validity}

\section{Self-Illness Separation (SIS)}

Based on the results of the Pearson's correlation test, the SIS value measured on the PRISM-D test showed a significantly negative correlation with the total BDI score $(\mathrm{R}=-.317, \mathrm{p}<.001)$. The result suggests that the higher the level of depression experienced by the patients, the closer they visualized their illness to the self.

Furthermore, SIS showed a significant negative correlation with the STAI-S scale, which measures the level of anxiety in participants $(\mathrm{R}=-.309, \mathrm{p}<.001)$. The result was that the higher the level of current anxiety a person experienced, the closer they drew their illness to the self. There was a significant, but weak, negative correlation between SIS and the STAI-T scale measuring trait anxiety levels $(\mathrm{R}=-.195, \mathrm{p}=.028)$. The result was that the higher the level of current and general anxiety a person experienced, the closer they drew their illness to the self. 
(Note: based on previous literature on the PRISM test, the SIS refers to the illness burden, 3.1.2.)

\section{Illness Perception Measure (IPM)}

Based on the results of the Pearson's correlation test, there was a significant positive weak correlation between the total score of the IPM and the BDI scale $(\mathrm{R}=1.83, \mathrm{p}=.36)$. The result suggests that the higher the level of depression the patient experienced, the greater his or her illness.

Furthermore, there was a significant weak correlation between the total score on the IPM and STAI-T scales $(\mathrm{R}=.214, \mathrm{p}=.013)$, which showed that the higher the degree of anxiety in a person in general, the higher their illness on the PRISM-D test. However, there was no significant correlation between the IPM and STAI-S scales.

(Note: Based on the literature on the PISM-D test, IPM refers to illness perception, 3.1.2.)

The results for convergent validity are summarized in Table 2 .

\begin{tabular}{|l|l|l|l|l|}
\hline \multirow{2}{*}{} & \multicolumn{2}{|l|}{ SIS } & \multicolumn{2}{l|}{ IPM } \\
\cline { 2 - 5 } & $\mathrm{R}$ & $\mathrm{p}$ & $\mathrm{R}$ & $\mathrm{p}$ \\
\hline BDI & $-.317^{* *}$ & $<.001$ & $.183 *$ & .036 \\
\hline STAI-S & $-.309 * *$ & $<.001$ & .068 & .356 \\
\hline STAI-T & $-.195 *$ & .028 & $.214 *$ & .013 \\
\hline
\end{tabular}

Table 2. Convergent validity. Note: Left side: correlation between the SIS represented on the PRISMD test and the BDI, STAI-S, and STAI-T total scores. Right side: correlation between IPM and the BDI, STAI-S, and STAI-T total scores. The table contains Pearson correlation coefficients (R) and significance values $(\mathrm{p})$ and level of significance $(*$ : correlation is significant at the $\mathrm{p}<.05$ level; **: correlation is significant at the $\mathrm{p}<.01$ level).

\subsubsection{Associations between illness circle position and depression and anxiety level -}

\section{Illness circle inside vs. outside the self}

Examining the position of the illness circle in the PRISM-D test in relation to the self circle, it can be said that there is a difference between level of anxiety of people who represent the illness within the self circle / in the case of a larger circle and those who draw the illness circle outside the self circle. Individuals who drew the illness within the self received significantly higher BDI scores than those who drew the illness outside the self (Student's t-test, $p=.004, \mathrm{df}=131$ ). 
There was a trend-level difference between those who drew the illness inside and outside the self circle for the total score on the STAI-S scale (Student's t-test, $\mathrm{p}=.059$, df $=185$ ). Based on the result, it can be said that individuals who drew their illness within the self experienced a higher level of current anxiety. The above correlation cannot be detected for the STAI-T scale. The above results are summarized in Table 3.

\begin{tabular}{|l|l|l|l|}
\hline \multirow{2}{*}{} & Significance level & $\begin{array}{l}\text { PRISM - Illness inside } \\
\text { self circle }\end{array}$ & $\begin{array}{l}\text { PRISM - Illness } \\
\text { outside self circle }\end{array}$ \\
\cline { 2 - 4 } & $\mathrm{p}(\mathrm{df})$ & Mean (stand. dev.) & Mean (stand. dev.) \\
\hline BDI & $.004(131)$ & $11.84(7.90)$ & $7.12(6.28)$ \\
\hline STAI-S & $.059(185)$ & $46.88(12.77)$ & $41.93(13.71)$ \\
\hline STAI-T & $.193(134)$ & $44.10(11.36)$ & $4.64(11.08)$ \\
\hline
\end{tabular}

Table 3. Associations between illness circle position and anxiety and depression level. Note: Student's t-tests: both the BDI and STAI-S total score was significantly different in the groups representing their illness inside or outside the self circle. The table shows significance values (p), degrees of freedom (df), and the group means (mean) and SDs (stand. dev.) of the two groups examined.

\subsubsection{Associations between other circle characteristics with anxiety and depression level}

\section{Representation of family}

Participants who drew at least one circle on the PRISM-D test that could be categorized as family (e.g., whole family, family members, partner) experienced significantly lower levels of anxiety than those who did not show any of their family members on the test (Student's t-test, $\mathrm{p}=.028, \mathrm{df}=170)$. Individuals who drew their family or its member(s) received an average of 41.57 points on the STAI-S scale ( $\mathrm{SD}=13.41)$, while those who drew scored -53.14 points (SD = 15.11). The number, size, and distance from the self circle of the circles that could be categorized into the family were not related to the total scores on the BDI and STAI scales.

\section{Illness-related factors}

Participants who displayed illness-related factors (health, recovery, surgery or other treatment and expected improvement, attitude and quality of service provided by physicians and health care personnel, and general hospital experience) experienced significantly lower anxiety level than those who did not even draw any of their family members (Student's t-test, $\mathrm{p}=.004$, $\mathrm{df}=$ 
168). Individuals plotting illness-related factors received an average of 36.82 points on the STAI-S scale $(\mathrm{SD}=11.15)$, while those who did not score 43.60 points $(\mathrm{SD}=13.93)$.

\section{Representations of negative stressors}

Patients who displayed circles that were categorized as negative stressors based on their report content (e.g., relational conflicts, experiences of loss, financial problems, earlier illnesses, fears, and thoughts on passing) received significantly higher overall BDI scores compared to patients who did not draw such a meaningful circle (Chi-squared test, $\mathrm{p}=.032$, df $=1$ ). Of those who drew negative stressors, $75 \%$ of them showed elevated levels of depression, while those who did not draw only $36.7 \%$.

For the other circles freely drew on the PRISM-D test, there was no correlation with the STAI and BDI scales ( $\mathrm{p}>.05$ in all cases). 


\section{STUDY 2: Applicability of the PRISM-D test to examine illness representations}

\subsection{Methods}

\subsubsection{Participants}

The study included 150 PRISM-D tests and its post-tests amongst 150 cancer patients under active hospital treatement. Participants suffered from one of the following types of tumors: breast cancer, gastro-intestinal cancer, hematopoietic tumor, melanoma malignum, cervical cancer, testicular cancer, lung cancer. All in all, $18.7 \%$ of participants were male, $81.3 \%$ were female, and their mean age was 56 years $(\mathrm{SD}=13.68)$.

The criteria for inclusion in the sample were as described in section 3.1.1, except for the disease group criterion (only cancer patients were included in the present study). The inclusion in the sample was random.The data collection conditions were as described in section 3.1.1.

\subsubsection{Measures}

\section{PRISM D}

A general description of the test can be found in section 3.1.2. In the present study, the distance from the self (SIS) and the area (IPM) of the circle symbolizing the illness were calculated. It was also examined whether recovery and health were displayed with distinct circles by the individuals.Post-test responses were analyzed based on several criteria, using the content analysis method. For the illness-circle, responses were categorized according to the following criteria: response to illness, illness-related emotional representations, illness perception, representations of related to outcome of illness. For each aspect of the analysis, the responses were categorized based on their meaning content. For circles symbolizing recovery and symbolizing health, post-test responses were also categorized based on their meaning. The categorization was performed by two independent encoders.

\subsubsection{Data analysis}

Statistical analysis of the data was performed with SPSS 21. For SIS and IPM, mean and standard deviation values were calculated. For the displayed health and recovery circles, as well as for the responses of the post-test categorized based on the criteria presented above, the response distributions were calculated (\%). 


\subsection{Results}

\subsubsection{Response to illness}

\section{Based on the spatial location of the illness circle}

The distance of the illness circle displayed on the PRISM-D test from the self circle (SIS) based on the literature measures the perceived burden of suffering due to illness (see section 3.1.2.). Based on our results, the participants drew their illness relatively close to the self on average $(\mathrm{M}=1.62 ; \mathrm{SD}=8.13)$, which suggests a high degree of mental suffering of the sample as a whole. However, it is important to note that the sample was characterized by a high degree of heterogeneity in this respect, as indicated by the high standard deviation. The lowest SIS value was 0 and the largest was $28.9 \mathrm{~cm}$.

In sum, $25.5 \%$ of patients described their illness as very close to their self, which may indicate increased mental suffering. Out of the participants, $18.8 \%$ drew their illness within the self (Figure $5 \mathrm{a}$ ) and $6.7 \%$ by touching the self.

Extremely high (greater than $20 \mathrm{~cm}$ ) SIS values were observed in $16 \%$ of the sample (Figure $5 b)$. Considering that all the interviewees were cancer patients currently undergoing treatment, this type of response suggests a denial of the illness.

The diversity of the spatial location of the illness circle is illustrated in Figure 5.

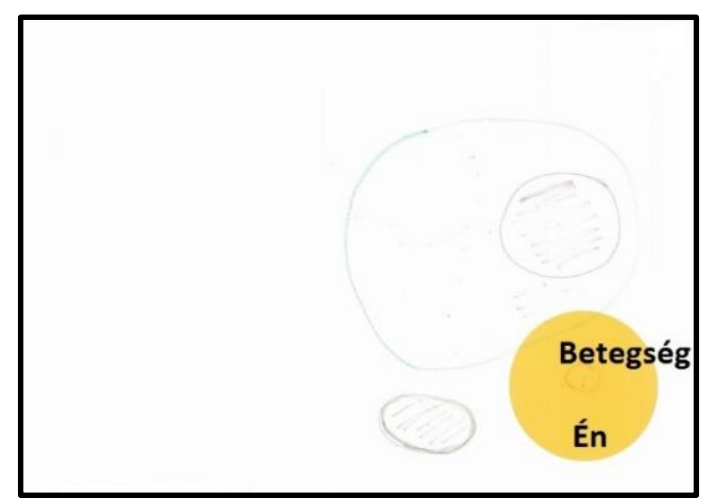

Figure 5a: PRISM-D test of a 58-year-old man with lung and liver cancer. Spatial location of the circle symbolizing the illness: small selfillness distance $(\mathrm{SIS}=.4 \mathrm{~cm}$ ), the illness within the self circle. Post-test: What does your illness represent in your life?: 'Scare. Fear of death.'

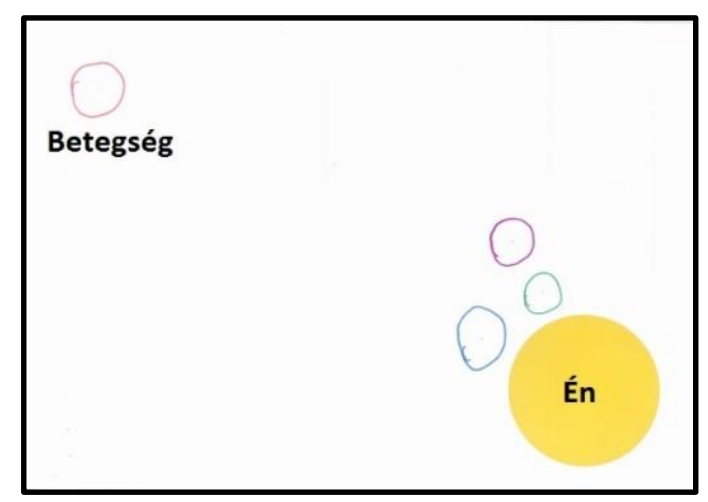

Figure 5b: PRISM-D test of a 68-year-old woman with colon cancer. Spatial location symbolizing the illness: large self-illness distance (SIS $=25.10 \mathrm{~cm}$ ). Post-test: What does your illness represent in your life?: 'I feel like there is none.' 


\section{Based on the post-test of illness circle}

In the content analysis of the PRISM-D test post-test, $64 \%$ of all responses had a report indicating a reaction to the illness. The most common response category was negative emotional reaction $(27.3 \%)$. Responses to increased distress or catastrophic illness were included in this category. The second most common response category was coping with the illness (16\%). Responses that indicated a specific coping response or a problem-oriented attitude toward the illness were included in this response category. Responses expressing understatement of the illness, distancing from the self, or even denial appeared with almost the same incidence (14\%). Another response category was integration into the self of the illness (4\%). These are responses that expressed that the illness had become part of them. Only $2.7 \%$ of the responses that could be categorized in this respect showed a response indicating acceptance of the illness. The frequency of the above response categories is shown in Table 4 to illustrate the responses associated with each category.

\begin{tabular}{|l|l|l|}
\hline Category & Frequency (\%) & Example \\
\hline Negative feeling, distress & $27.3 \%$ & "Emotionally devastated." \\
\hline $\begin{array}{l}\text { Coping, problem-focused, } \\
\text { solution-seeking attitude }\end{array}$ & $16 \%$ & $\begin{array}{l}\text { "It can be coped with, so I will overcome } \\
\text { it." }\end{array}$ \\
\hline $\begin{array}{l}\text { Denial, understate illness, } \\
\text { distancing from self }\end{array}$ & $14 \%$ & $\begin{array}{l}\text { "I feel there is none. As if it had not } \\
\text { happened to me." }\end{array}$ \\
\hline Integrating into self & $4 \%$ & $\begin{array}{l}\text { "This determines my life to a great } \\
\text { extent; it is within me greatly." }\end{array}$ \\
\hline Acceptance & $2.7 \%$ & $\begin{array}{l}\text { "It was bad at the outset, now I have } \\
\text { accepted it, I am living with it." }\end{array}$ \\
\hline
\end{tabular}

Table 4: The table shows the response categories of the post-test of the PRISM-D illness symbolization circle based on the content analysis of the responses with the meaning of the response to the illness. Percentage data indicate the relative incidence of each category. The example sentences illustrate each response category.

\subsubsection{Illness-related representations}

\section{Illness perception - Based on the size of the illness circle}

Based on the literature on the PRISM test (see section 3.1.2.), the size of the illness displayed on the test refers to Illness Perception Measure (IPM). Due to the freedom of representation provided by the drawing test version, the size of the circle symbolizing the illness could be determined by the participants completely individually. 
The size of the illness circles averaged $12.75 \mathrm{~cm}^{2}$, however, the large SD (SD = 24.57) indicates large individual differences. The largest illness circle was $254.46 \mathrm{~cm}^{2}$, indicating a circle $9 \mathrm{~cm}$ in diameter, and the smallest $.01 \mathrm{~cm}^{2}$, which actually indicates a tiny dot. In sum $42 \%$ of the participants reported their illness as very small, less than $1 \mathrm{~cm}$ in diameter $\left(3.14 \mathrm{~cm}^{2}\right.$ circle)

Regarding the size of the illness circle in relation to the self circle, it can be said that the participants displayed the illness on average smaller $\left(\mathrm{M}=12.75 \mathrm{~cm}^{2}\right)$ compared to the circle representing the self $\left(153.86 \mathrm{~cm}^{2}\right)$. Taking into account the answer distributions, it can be said that $88.7 \%$ of the respondents showed an illness smaller than the self, $6.7 \%$ were of almost the same size, and only $4.7 \%$ were larger than the self circle.

The large differences between the illness circles displayed on each test are illustrated in Figure 6.

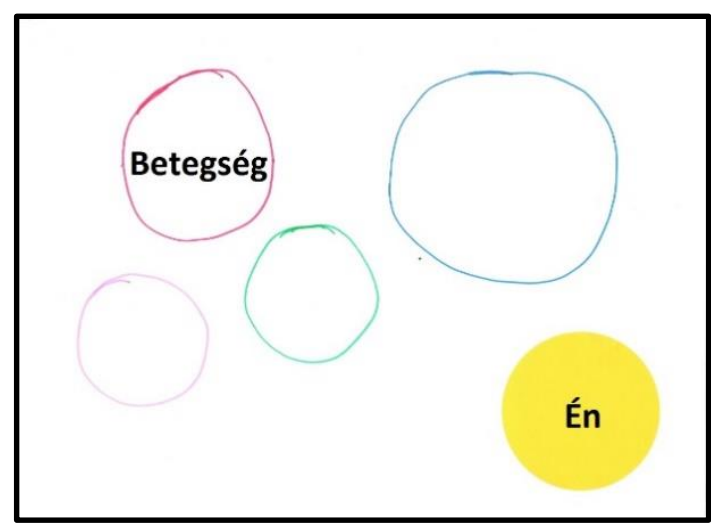

Figure 6a: PRISM-D test of a 68-year-old woman with breast cancer. The size of the illness circle is large (IPM $\left.=38.47 \mathrm{~cm}^{2}\right)$. Posttest: What does your illness represent in your life? 'The illness is badly affected.'

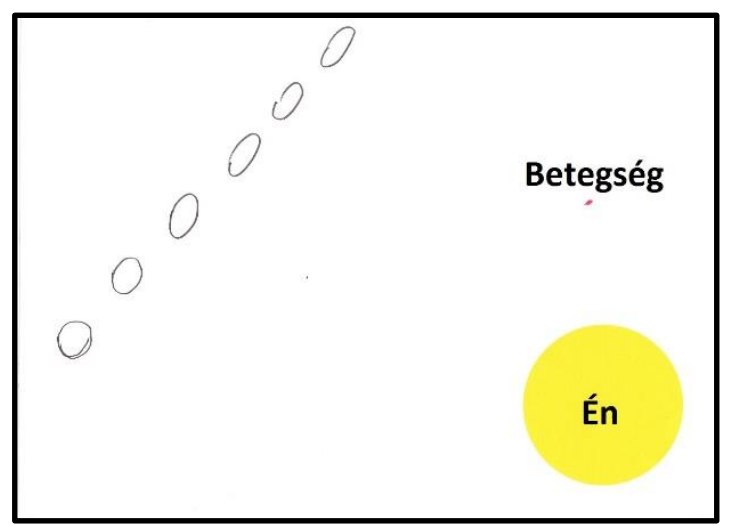

Figure 6b: PRISM-D test of a 43-year-old woman with breast cancer. The size of the illness circle is small (IPM $\left.=.08 \mathrm{~cm}^{2}\right)$. Post-test: What does your illness represent in your life?: 'I want to get over the illness. Recovery.'

\section{Illness perception - Based on post-test of the illness circle}

During the content analysis of the post-tests, we found content related to illness representation in $36 \%$ of responses related to illness. During the categorization of responses indicating illness representation based on meaning content, the following illness interpretation categories were identified: illness as an sign / change (31.5\%), obstacle / difficulty (25.9\%), task to be solve (18.5\%), loss (7.4\% ) struggle, (5.55\%), hit (5.55\%), personal failure (5.55\%) (Table 5).

In depicting the illness as a symbol, the illness was described as a lightning strike from a clear sky, a slap. 


\begin{tabular}{|l|l|l|}
\hline Category & $\begin{array}{l}\text { Frequency of } \\
\text { occurrence } \\
(\%)\end{array}$ & Example \\
\hline Sign / change & $31.50 \%$ & $\begin{array}{l}\text { "I was shocked at what I had messed up. I need to } \\
\text { go in a new direction." } \\
\text { "It is a necessary evil that makes me change my life } \\
\text { and thinking." }\end{array}$ \\
\hline Obstacle / difficulty & $25.90 \%$ & $\begin{array}{l}\text { "It is a huge burden. This is what I got from destiny, } \\
\text { I need to tolerate it." } \\
\text { "It is an impeding factor." }\end{array}$ \\
\hline Task & $18.50 \%$ & $\begin{array}{l}\text { "Problem that needs to be solved." } \\
\text { "Task to be solved." }\end{array}$ \\
\hline Loss & $7.40 \%$ & $\begin{array}{l}\text { "Wasted time." } \\
\text { "It puts everything into the background." } \\
\text { "Breaking up a career." } \\
\text { "It hinders me in a lot of things. It turns my life } \\
\text { upside down." }\end{array}$ \\
\hline Hit & $5.55 \%$ & $\begin{array}{l}\text { "Slap in the face. I lived a healthy life, it comes out } \\
\text { of the blue." }\end{array}$ \\
\hline Failure & $5.55 \%$ & $\begin{array}{l}\text { "I want to fight until it is possible." } \\
\text { "It is anscious." }\end{array}$ \\
\hline
\end{tabular}

Table 5: The types of illness interpretation categories formulated in the post-test of the illness circle, the percentage distribution of responses that can be categorized in this respect, and example sentences.

\section{Illness-related emotional representations - Based on post-test of the illness circle}

Illness-related circle-related post-test responses included illness-related emotional representation ( $4.9 \%$ negative emotional response, $2.1 \%$ neutral or positive). Of the responses from all post-tests, the following emotional representations were formulated: generally bad feeling (11.3\%), distress (8.7\%), fear (4.4\%), sadness (2.7\%), surprise (2.7\%), uncertainty $(2 \%)$. There were emotional contents formulated with a frequency of less than $2 \%$ : helplessness, hopelessness, remorse, mental shock.

\section{Representations of related to outcome of illness - Based on post-test of the illness circle}

In $16 \%$ of the responses to a post-test related to the illness circle, response contents indicating illness outcome were formulated. According to the results of the content analysis, the majority 
of responses categorized in this respect (91.87\%) referred to a positive outcome of the illness (belief in recovery, positive future changes). Only $8.13 \%$ of illness outcome responses and $1.3 \%$ of all responses had negative outcome responses (illness exacerbation, death, and fear of these).

\section{Representations of related to outcome of illness - Based on circles symbolizing recovery and health}

In sum, $13.4 \%$ of participants drew a distinct circle representing recovery in the PRISM-D test. In the answers to the post-test (What does the recovery represent in your life?) the following response contents appeared: recovery as a value (importance of recovery), recovery as a goal, faith in recovery, desire for recovery, recovery as a miracle.

All in all, $14.6 \%$ of the cancer patients in the study drew a distinct circle representing their health in the test. In the answers to the post-test (What does the health represent in your life?) the following response contents appeared: health as a value (emphasizing the importance of health), health as life, health as happiness, health as a goal to be achieved.

The above results are summarized in Table 6.

\begin{tabular}{|c|c|c|}
\hline \multicolumn{3}{|l|}{ Recovery } \\
\hline Displayed (\%) & \multicolumn{2}{|l|}{$13.4 \%$} \\
\hline \multirow{5}{*}{ Meaning } & Value & "The most important in my life." \\
\hline & Goal & $\begin{array}{l}\text { "This is the most important goal so that everything will } \\
\text { be back in place." }\end{array}$ \\
\hline & Faith & "I believe in it, but it is difficult." \\
\hline & Desire & "I would like to heal." \\
\hline & Miracle & "It would be a miracle." \\
\hline \multicolumn{3}{|l|}{ Health } \\
\hline Displayed (\%) & \multicolumn{2}{|l|}{$14.6 \%$} \\
\hline \multirow{4}{*}{ Meaning } & Value & $\begin{array}{l}\text { "It is the most important thing. We realize it when we } \\
\text { are in danger." }\end{array}$ \\
\hline & Life & "My life." \\
\hline & Happiness & "Happiness" \\
\hline & Goal & "Goal to be reached." \\
\hline
\end{tabular}

Table 6: The PRISM-D test shows the display rate (\%) of the circles symbolizing recovery and health, as well as the report categories of the answers to the related post-tests with example sentences. 


\section{STUDY 3: Applicability of the PRISM-D start test to examine perceived social support}

\subsection{Methods}

\subsubsection{Participants}

The study involved 194 patients with severe somatic illness undergoing active hospital treatment. Participants were selected from the following disease groups: cancer patients (56.2\%), patients with chronic renal insufficiency (3.8\%), and gastro-intestinal patients requiring surgery (13.0\%). $31 \%$ of the participants were male and $68.6 \%$ were female. Their mean age was 52.77 years $(\mathrm{SD}=14.89)$.

The nature of the data collection, the conditions, and the criteria for inclusion in the sample were as described in 3.1.1 (except for the disease group section, as only participants with cancer, gastro-intestinal and chronic renal insufficiency were included in the present study).

\subsubsection{Measures}

\section{PRISM D}

A general description of the test is given in section 3.1.2. In the present study, the Self-Illness Separation (SIS) and the IPM value for the illness circle were calculated. In the case of freely drawn circles, only responses that could be classified as social support based on their report content (e.g., family member, partner, friend, relative, acquaintance, neighbor, etc.) were analyzed. The categorization of responses based on meaning content was performed by two independent encoders. Only responses were included in the category for which the post-test responses confirmed that the individual(s) provided emotional and / or instrumental support to the patients.

During the analysis, the distance of the self circle and the social support circle was calculated. If the patients displayed social support with multiple circles, we calculate (1) the distance from the self circle and the social support circle closest to the self, and (2) the average distance of all displayed social support factors from the self was calculated. In addition, the area of the circle symbolizing social support was calculated (if it was displayed with several circles, the areas of each circle were added together).

STAI (see section 3.1.2.)

BDI (see section 3.1.2.) 


\subsubsection{Data analysis}

Data analysis was performed with SPSS version 21. For circles symbolizing illness and social support displayed on the PRISM-D test, response distributions, means, and SDs were calculated. For the STAI and BDI tests, the mean of the total scores of the scales and the SDs were calculated. Student's t-test was used to analyze the relationship between social support and depression and anxiety levels.

\subsection{Results}

\subsubsection{Social support circle's characteristics}

\section{Characteristic features of displaying social support}

The majority of the participants, $95.7 \%$, drew at least one circle referring to their family or a certain member(s) of it based on the response of the post-test. Only $4.3 \%$ of patients did not draw a family member or other social support person, which may suggest a perceived social isolation. $72.7 \%$ of the participants drew not only their family / member but also other social support person(s) (.e.g., friend, colleague, neighbor). Amongst the respondents, $36 \%$ of them, a circle symbolized social support (it could symbolize either a person or the whole family). In sum, $64 \%$ of them, on the other hand, using the possibility of free representation, depicted the members of the social support environment by drawing several circles.

\section{Social support circle(s) size}

The average area of the social support circles drawn on the test was $36.99 \mathrm{~cm}^{2}$ ( $\mathrm{SD}=52.93$ ) (if the subject represented social support using multiple circles, the area values of each circle were added up), which is minimally smaller than the size of the self circle (with an area of 38.48 $\left.\mathrm{cm}^{2}\right)$. However, they were larger than the size at which the illness was generally drawn $(\mathrm{M}=$ $\left.16.29 \mathrm{~cm}^{2}, \mathrm{SD}=33.11\right)$. Although this result suggests that participants felt, on average, their illness was smaller and social support was perceived to be higher, the generalization of the result should be treated with caution due to large standard deviations.

Analyzing this further, it can be said that although the majority of the participants, $71.2 \%$, drew social support higher than the illness, the above finding cannot be generalized to the other participants. In sum $2.6 \%$ of respondents drew social support and illness to nearly the same size, suggesting a balance between the importance of the two factors. All in all $23.7 \%$ of them 
drew the illness to a greater extent and social support to a smaller one. In their case, the illness is presumably of greater subjective significance than social support.

\section{Social support circle(s) distance from self circle}

Since some participants depicted social support with multiple circles and the other with only one, we worked with multiple indicators of distance values. On the one hand, we calculated the distance of the nearest social support circle from the self circle, which was $9.15 \mathrm{~cm}$ on average $(\mathrm{SD}=5.49)$. On the other hand, we calculated the average distance of all social support circles from the self circle, which averaged $11.10 \mathrm{~cm}(\mathrm{SD}=5.8)$ (note: if the subject drew only one social support circle, both values were the same).

Participants drew illness on average $11.59 \mathrm{~cm}$ from the self circle (SIS; SD = 7.77), a distance nearly equal to the mean distance of all social support factors from the self circle and slightly larger than the distance of the circle indicating the self circle closest to the social support. However, large standard deviations indicate large individual variability. All in all, $56.8 \%$ of participants drew social support closer to the self circle and illness more distant. And 43.2\% drew the illness closer to the self circle.Descriptive statistics related to the illness and social support factors displayed on the test are shown in Table 7.

\begin{tabular}{|c|c|c|c|c|}
\hline & & $\begin{array}{l}\text { Was it } \\
\text { displayed? }(\%)\end{array}$ & $\begin{array}{ll}\text { Distance } & \text { from } \\
\text { self circle } & \end{array}$ & Size \\
\hline \multicolumn{2}{|l|}{ Illness } & $100 \%$ & $\begin{array}{l}M=11.59 \\
(\mathrm{SD}=7.77)\end{array}$ & $\begin{array}{l}M=16.29 \\
S D=33.11\end{array}$ \\
\hline \multirow{2}{*}{$\begin{array}{l}\text { Social } \\
\text { support }\end{array}$} & $\begin{array}{l}\text { Social support circle } \\
\text { drawn the closest }\end{array}$ & \multirow{2}{*}{$95,7 \%$} & $\begin{array}{l}\mathrm{M}=9.15 \\
(\mathrm{SD}=5.4)\end{array}$ & \multirow{2}{*}{$\begin{array}{l}\mathrm{M}=36.99 \\
(\mathrm{SD}=52.93)\end{array}$} \\
\hline & $\begin{array}{l}\text { Mean of all social } \\
\text { support circles }\end{array}$ & & $\begin{array}{l}\mathrm{M}=11,10 \\
(\mathrm{SD}=5.8)\end{array}$ & \\
\hline
\end{tabular}

Table 7: Frequency of representation of circles symbolizing the illness circle and social support displayed on the PRISM-D test, and the distance and size of the above factors from the self circle. $(\mathrm{M}=$ mean, standard deviation $=\mathrm{SD}$ )

\subsubsection{Relationship of social support circle's characteristics to illness circle, depression, and anxiety levels}

\section{Did it display social support?}

Our results showed that patients who did not plot social support on the PRISM-D test scored significantly higher on the STAI-S scale. This means that those who did not represent any social 
support person within their current living environment experienced a higher level of current anxiety, $(M=53.14, S D=15.11)$ than those who indicated member(s) of their social support area to any extent $(\mathrm{M}=42.34, \mathrm{SD}=13.52)$ (Student's t-test, $\mathrm{p}=.040, \mathrm{df}=181)$. A similar correlation was found for the STAI-T scale. Thus, patients who did not show social support on the test had significantly higher trait anxiety scores $(\mathrm{M}=5.33, \mathrm{SD}=15.37)$ than those who plotted $(\mathrm{M}=37.85, \mathrm{SD}=1.35)($ Student's t-test, $\mathrm{p}=.005, \mathrm{df}=153)$. (Table 8.)

The above results suggest that individuals who, for some reason, did not feel it was important to display a social support person in their current living environment (either due to perceived or real lack or focus on something else) experienced greater anxiety. However, the size of the social support factors drawn in the test and the number of circles that could be classified as social support were not significantly related to the level of anxiety experienced (all p> .05).

\begin{tabular}{|l|l|l|l|}
\hline & Significant level & $\begin{array}{l}\text { Social support was } \\
\text { displayed }\end{array}$ & $\begin{array}{l}\text { Social support was not } \\
\text { displayed }\end{array}$ \\
\cline { 2 - 4 } & $\mathrm{p}(\mathrm{df})$ & Mean (SD) & $53.14(15.11)$ \\
\hline STAI-S & $.040(181)$ & $32.34(13.52)$ & $5.33(15.37)$ \\
\hline STAI-T & $.005(153)$ & $37.85(1.35)$ & Mean (SD) \\
\hline
\end{tabular}

Table 8: Relationship between social support and anxiety level drew on a PRISM-D test. There is a significant difference between the total STAI-S and STAI-T scores based on whether participants displayed their illness on the PRISM-D test (Student's t-test). The table shows the significance value (p), the degree of freedom (df), and the mean score values (Mean) and the SD (Stand. Dev.) characteristics of the groups for the two studied groups.

\section{Absolute distance of social support circle(s) from the self circle}

The absolute distance from social circle of self circle drawn closest to the self circle, symbolizing social support, was significantly associated with illness perception measure (IPM), but was not associated with depression and anxiety levels. Individuals who displayed the circle symbolizing social support closer to the self circle drew their illness significantly less sizeable $(M=9.086, S D=12.28)$ than those who drew social circle farther $(M=22.39), S D=49.50)$ (Student's t-test, $\mathrm{p}=.047, \mathrm{df}=72.82$ ). (Note: IPM refers to illness perception based on the literature, see section 4.1.2.) A similar result was found for the mean distance of all circles symbolizing social support factors from the self, although in this case the association was only trend-level (Student's t-test, $\mathrm{p}=.068$ ).

The above results may suggest that individuals, who felt closer social support, were currently experiencing a closer relationship(s), felt less significant about their illness. However, 
individuals who did not feel so close to social support presumably attached more subjective importance to their illness and presumably placed a greater burden on them.

\section{Relative distance of social support circle from self circle}

Examining the relative position of social support circle and illness, it can be said that persons who drew the illness closer to the self and social support farther away showed significantly higher depression values $(\mathrm{M}=9.47 ; \mathrm{SD}=7.08)$ than those who drew social support closer to the self circle and illness more distantly $(\mathrm{M}=7.60 ; \mathrm{SD}=6.80)$ (Student's t-test, $\mathrm{p}=.016, \mathrm{df}=$ 91). A similar result was obtained for the condition anxiety value (Student's t-test $\mathrm{p}=.027$, df $=142$ ). Patients who drew social support farther and illness closer to the self circle received an average of 45.07 points on the STAI-S scale (SD = 13.99), while those who drew social support closer to the self received 41.07 points $(\mathrm{SD}=12.85)$ (In the data analysis, the distance from the self closest to the circle symbolizing the self was taken as the basis of the circle classified as social support).

Our results suggest that if there is social support between the self and the illness, the person will experience a lower level of anxiety and fewer depressive symptoms. If, on the other hand, the illness wedges between the self and important others, the person will experience an increased degree of anxiety and depressive symptoms.

The above relationship is demonstrated in Figure 7.

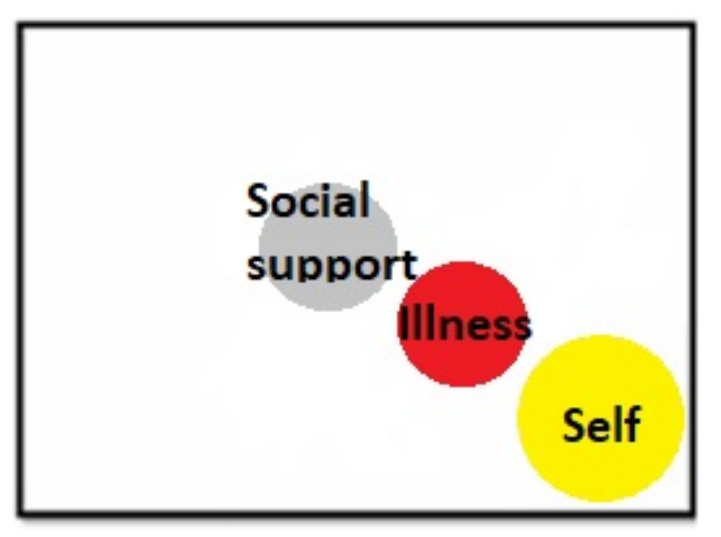

Figure 7a. (Illustrative figure): The social support circle is further away, the illness cirlce is closer to the self circle. SIS: $M=6.14$ ( $\mathrm{SD}=$ 6.20), social support-self distance: $\mathrm{M}=11.21$ $(\mathrm{SD}=11.15)$, BDI: $\mathrm{M}=9.47(\mathrm{SD}=7.08)$, STAI-S: $M=45.07(\mathrm{SD}=13.99)$

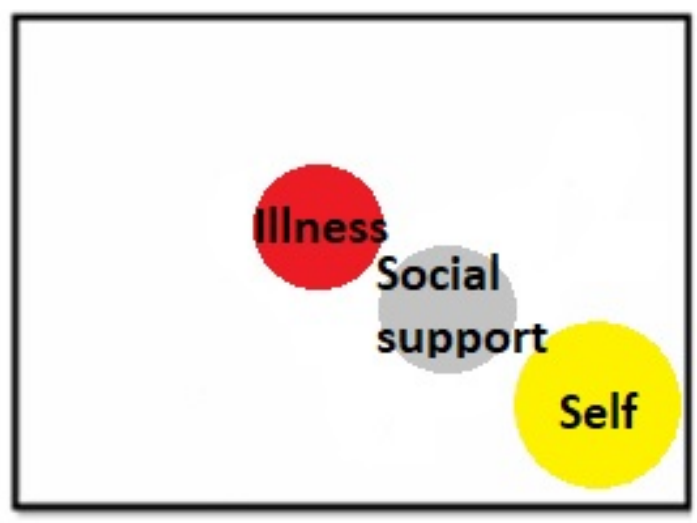

Figure 7b. (Illustrative figure): The social support circle is closer, the illness circle is farther away from the self circle. SIS: $M=15.10$ $(\mathrm{SD}=14.55)$, social support-self distance: $\mathrm{M}=$ 7.60 (SD = 6.80), BDI: $\mathrm{M}=6.27$ ( $\mathrm{SD}=5.39)$, STAI-S: $\mathrm{M}=41.07(\mathrm{SD}=12.8)$ 


\section{DISCUSSION}

The purpose of the doctoral research was to present the method development process of the drawing test version of the PRISM test, a visual metaphor successfully used among somatic patients. As a first step in the doctoral research, the validation process of the PRISM-D test was performed in STUDY 1. The goal was to test whether the modified version retains the benefits of previous test versions and whether the new measure provides additional information over previous versions. Data collection from a sample of 500 somatic patients under active hospital treatment revealed that the instructions for the drawing test version of the PRISM test were understood by the participants, and in our experience, the test recording was easy and quick to perform.

According to our results, the drawing version of the test can adequately integrate the advantages of earlier PRISM test versions and conventional drawing tests. The elimination of the metal disks and thus the application of the test as a drawing test not only reduce the number of tools necessary but also enable easier and more economical application in clinical practice, giving the patients the opportunity of free visualization. As the data collection was performed amongst a wide range of somatic patients (cancer, gastro-intestinal, chronic renal insufficiency, lumbar degenerative disc disease), our results suggest that the measure can be used in a wide range of somatic patients, regardless of illness type. The results obtained are also independent of gender and age variables.

The drawing test version of the PRISM test, like previous versions of the test, allows you to measure your suffering from the illness. According to the original version of the test, the distance between the self circle and the illness circle (Self-Illness Separation, SIS) can be interpreted as the perceived suffering of the illness burden. According to our results, we did not lose the reliability of the test during the modification, as the SIS showed a significant, negative correlation with the total score on the BDI, which corresponds to the results of the original PRISM test (Büchi et al., 1998; Büchi et al., 2002; Rumpf, Lontz \& Uesseler, 2004; Klis et al., 2008; Büchi et al., 2009; Wittmann, Schnyder \& Büchi, 2012; Lima-Verde et al., 2013; Gielissen et al., 2013; Meyer et al., 2014). Furthermore, we found a significant negative correlation between the SIS and the scales of the STAI. This result is also consistent with the results of previous studies, as research using the original PRISM test has shown a significant association between stress perceived during anxiety / illness and SIS (Krikorian et al., 2013; Klis et al., 2008). Regarding the strength of the correlation coefficients obtained in the present 
study, it can be stated that they have almost the same strength as the correlation coefficients found in previous research on the PRISM test.

Based on the results of the study, in the PRISM-D test, in addition to the SIS, it is worthwhile to examine the spatial position of the illness circle, as well as the relative position of the self and the illness circle. It is advisable to distinguish two categories: (1) the circle of illness within the self circle / overlapping with the self (in case the circle of illness is larger than the self circle); (2) the illness circle outside the self circle. According to our results, the two illness circle positions are associated with different levels of depression and trait anxiety. The result suggests that patients who experienced their illness inside their selves experienced a more negative mood and a higher degree of anxiety than those who experienced their illness outside their selves. A similar correlation was shown with an earlier version of the PRISM test (Peter et al., 2016), where the spatial position of the illness circle relative to the self circle was significantly associated with depression levels and quality of life.

The drawing test version, as well as the PRISM-R1 test (Reimus et al., 2007), allow the measurement of illness perception (IPM; due to the size of the illness circle). However, while with PRISM-R1, patients were able to choose from three fixed-size illness discs, in the drawing test version, patients were free to determine the size of the illness circle. The results showed that patients took advantage of the possibility of free representation, as the illness circles took very different sizes, from a tiny dot of a few millimeters to a red circle covering the entire sheet. As a result, we found a significant correlation between the values of the IPM and the total scores of the BDI and STAI-T. The above results are consistent with research findings related to PRISM-R1 (Reimus et al., 2007; Klis et al., 2008). For example, Reimus et al. (2007) found a significant association between IPM and health status, life statistics, and psychological wellbeing in patients with psoriasis. In the study of Klis et al. (2008), there was also a significant correlation between the PRISM-R1 IPM index and well-being. Thus, it can be concluded that the reliability of the test was not compromised by modifying the test, as we obtained similar results with the free choice of the patient population as in the studies using fixed-size discs. In our view, free representation also offers additional benefits, allowing more room for patients to express their perceptions of illness and to communicate individual experiences - although further research is needed to examine this.

The results related to the size of the illness drawn on the PRISM-D test are related to the research results related to traditional drawing tests, which also showed that the size of the illness 
drew in the drawings is related to the emotional-mood indicators. For example, a study by Reynolds et al. (2007) found a correlation between the size of the heart drawings of patients who underwent health failure and health-specific anxiety. In a study by Látos et al. (2012), a similar result was found among kidney transplant patients where they measured a correlation between the level of anxiety and the size of patients' transplanted kidney drawings. Further research, also with drawing tests, has found that the size of the displayed illness is associated with a more negative illness perception (Broadbent et al., 2019). Overall, therefore, it can be concluded that the size of the illness circle drawn on the PRISM-D test is similarly informative as the size of the illness depicted on conventional drawing tests. However, in the case of the PRISM-D test, the schematic, circular representation greatly facilitates the task of the test persons, no drawing talent is required to perform the task, and the analysis of the tests is significantly simpler than in the case of more differentiated drawings, drawing ability does not affect the analysis.

An additional benefit of the PRISM-D test is that it allows patients to freely represent the important factors present in their actual lives without restricting them to a fixed order, size, or relative placement. The PRISM-D test operates without predefined categories of meaning. Participants may freely connect meanings to the circles drawn, allowing the exploration of subjective representations. In this way, the test can be adapted to measure patients' visualizations of their illness, as well as explore the extent to which their illness affects their lives. Furthermore, it allows the exploration of potential resources, factors that promote recovery, but also obstacles, difficulties, problem sources, and factors that hinder recovery and other difficulties in the individual's life. The visual representation of these, the order in which the factors are drawn, their size and location relative to each other, self and illness can all be very informative, although due to the heterogeneity of the data it does not allow quantitative analysis. But, the individual and patient-oriented interpretation and evaluation allows the patients deeply understanding. Drawing also makes it possible to connect the individual factors, to create spatial formations, the interpretation of which can form the basis of further qualitative research.

The PRISM-D test is different from the PRISM + version in that while in PRISM + participants were given magnetic disks with a fixed meaning that they had to place within their living environment, in the case of PRISM-D, patients were free to decide how much, what the size and meaning of the circles are drawn. Thus, not only the distance and spatial position of each factor from the self and illness can be measured, but it can also be eloquent in itself what 
meaning circles have been drawn, how many circles, and how large. In this way, we can get an idea of the subjectively important factors currently present in the living environment, their relationship to illness, self and each other. It can be informative if certain factors are not displayed by the patient (e.g. family), and the test can be used to get an idea of the emptiness of the living environment or its richness.

In our study, patients drew an average of 5.81 circles, including the illness circle, suggesting that patients took advantage of free visualization. However, a very large individual variability was observed in the number of circles $(\mathrm{SD}=2.86)$. It is important to note that $1 \%$ of the participants were unable to display any factors other than their illness, which is definitely an alert sign.

Examining the meaning of each circle, the resources that potentially help recovery, as well as the factors, obstacles and problems that may hinder it, can also be explored. It may be informative which of the circles was drawn first, as this may indicate the subjective importance of the particular factor. The most common first-time drawn factors in our study were family / family members $(74.4 \%)$, friends $(1.4 \%)$, their recovery $(3.7 \%)$, and things related to their illness or its treatment ( e.g., surgery, illness treatment, hospital staff) (3.4\%).

As a result of the examination of each of the displayed circles, it can be said that the most common response category among the participants was social support. 92.3\% indicated their family or its members with a distinct circle / circles, and $24.1 \%$ indicated friends. Only $6.6 \%$ of the participants did not show a social support person, which should be interpreted as a call sign, it can also indicate a real lack of social support, but also its inadequate functioning, relationship problems, difficulty in activating social support, perceived social isolation, or perhaps a narrowed focus on illness. The presence of social support and its appropriate mobilization is of paramount importance for recovery (Wills \& Fegan, 2001).

Our study found that individuals who did not display any of their family members experienced significantly higher levels of anxiety than their fellow patients who drew at least one family member. Our above finding is consistent with research findings that social support can buffer distress and thus exert its positive effects (Theory on Stress Buffering; Cohen \& Wills, 1985; Thoits, 1982). Based on this theory, individuals who did not perceive any social support in their current living environment presumably experienced higher anxiety because supporting individuals were unable to perceive and reduce the patient's anxiety. 
Another interesting result is that a significant proportion of patients (31.6\%) drew factors related to their illness, its treatment, recovery, or health. This may be informative because it is known from the literature that confronting the illness and its concomitants greatly aids psychological adaptation to the illness (de Ridder et al., 2008). Our results also indicate that mental representation of the illness and its treatment has a positive effect in the short term, as patients who have demonstrated illness-related factors (e.g., surgery or other treatment and expected improvement, recovery, attitude and quality of service provided by physicians and health care personnel, general hospital experience, importance of health), experienced significantly lower anxiety than those who did not draw such factors. The above result also draws attention to the importance of mentally representing and raising awareness of illnessrelated factors in severe patients undergoing hospitalization and sharing it with social environment (e.g., during test enrollment with the test leader). Since the displayed response contents, e.g. confidence in the success of health, recovery, treatment basically reveals positive representations about recovery, so in these cases, the association with lower levels of anxiety is not surprising. However, the correlation can also be observed for responses where respondents displayed some factors of hospitalization, e.g. hospital staff, fellow patients, various forms of treatment. In our opinion, raising awareness of the above factors and displaying them on the test further strengthens the positive representations related to recovery.

Another important observation of our study is that the test is suitable for detecting negative factors present in the lives of patients. Based on our results, $5.9 \%$ of the patients displayed the negative stressors present in their lives during the freely visualization. Some of the drawn negative factors were related to the illness, e.g. fear of death, pain, while other responses were related to other aspects of living environment, e.g. loss experiences (death, divorce), relationship conflicts, and financial difficulty. Our further results showed that individuals who drew a negative stressors experienced a significantly higher rate of elevated depression levels than those who did not plot. While these findings are not surprising, they are important because they further show the usability of the new method.

In our opinion, the revealing of the above negative factors is extremely important for clinical work, as they can greatly complicate the recovery process, and they also imply the increased presence of depressive symptoms. The PRISM-D test could contribute to the quick and easy exploration of these negative factors and to the screening of patients who have factors in their life that may aggravate physical and psychological recovery. The drawing of negative factors should be considered a useful sign of attention, and it is worthwhile to deal these factors in 
further psychological intervention for the sake of physical and mental recovery. Nevertheless, the qualitative aspects of the individual meaning of contents need to be analyzed by further research.

As the second step of the research, in STUDY2, our aim was to investigate how the PRISM-D test and its post-test are able to reveal illness-related representations. This is because the method development research confirmed that the area of the illness drawn in the test is suitable for measuring the illness perception (IPM) in a similar way to the PRISM-R1 version. However, the above research did not analyze the qualitative data set obtained in the post-test of the PRISM-D test. In the second study, PRISM-D tests and post-tests of 150 cancer patients under active hospital treatment were analyzed using quantitative and qualitative techniques (content analysis).

According to our results, the cancer patients we studied experienced underwent considerable suffering due to illness, as indicated by the SIS value measured on the PRISM-D test. However, the large SD value suggests that the degree of suffering experienced by the patients studied shows great individual variability.

In the content analysis of the post-test responses (What does your illness represent in your life?), we found, that the $64 \%$ of the responses had a report indicating a reaction to the illness. Of the responses that could be categorized in this respect, the most common was a negative emotional reaction, distress $(27.3 \%)$. The above result is related to data in the literature that one of the most common reactions to illness is increased distress and anxiety (Noyes, Holt \& Massil, 1998), which affects 35-38\% of cancer patients (Zabora et al., 2001; Carlson et al., 2004). Whereas research has shown that increased distress and anxiety can negatively affect recoveryrelated processes (Broadbent et al., 2003; Marucha, Kiecolt-Glaser \& Favagehi, 1998; KiecoltGlaser et al., 1998; Johnston, 1988; Matthews-Ridgeway, 1981; Kehlet, 1997; Kemeny \& Gruenewald, 2000), so that this type of reaction is to be interpreted as a sign of attention, and its detection is of paramount importance for effective patient care.

Participants' analysis of responses to illness also identified favorable psychological responses to illness, such as coping / problem-focused attitude (16\%), integration of the illness into the self (4\%), and acceptance of the illness $(2.7 \%)$. However, there was a relatively high response rate to illness denial or understate the illness $(14 \%)$. 
In our study, we identified a sign of denial not only in the post-test responses, but also in terms of the spatial position of the illness, we identified a group of respondents (16\%) who drew their illness at an extreme distance from the self, typically in the other corner of the page. This type of representation, also given that the cancer patients in the sample were undergoing active hospital treatment, was also perceived as a sign of denial. Our results draw attention to the fact that a non-negligible proportion of the studied patient population developed a rejection reaction, which according to previous research is relatively common in cancer patients (Vos \& de Haes, 2007). According to some studies, in cancer patients, denial of diagnosis occurs in $4-47 \%$, denial of impact occurred in 8-70\%, and denial of emotions in $18-42 \%$ (Vos \& de Haes, 2007). Effective detection of a denial response is of paramount importance because, although it can be beneficial in the early stages of the illness at diagnosis by reducing increased distress and anxiety, it has a distinctly negative effect later in the illness during active treatments, as it can interrupt spiritual processing and can deprive the person of the opportunity to cope (Kreitler, 1999). In our opinion, the great advantage of the PRISM-D test and its post-test is that it is able to detect possible denial reactions in several ways, both verbally and nonverbally, so it can greatly help the clinical work.

We found that $43 \%$ of all responses in the post-test expressed emotional representations. Most of the responses referred to negative emotional content such as feeling bad, distress, fear, sadness, negative surprise, insecurity, helplessness, hopelessness, remorse, mental shock. Only $2.1 \%$ of all responses expressed a positive emotion about the illness. In our opinion, the detection of feelings related to the illness is important for both screening and psychological intervention, and patients can already benefit from being able to express these feelings for themselves and an external person (test leader / specialist).

Another important result is that the test is able to differentiate the measurement of illness perception, which according to the literature is extremely important, as it is related to several recovery-related processes (Krikorian et al., 2014; Petrie \& Weinman, 2012; Anagnostopoulos \& Spanea, 2005; Dempster, Howell \& McCorry, 2015; Weinman \& Petrie, 1997; Hagger \& Orbell, 2003; Juergens et al., 2009; Cherrington et al., 2004; Petrie et al., 1996; Lacroix et al., 1991; Büssing \& Fischer, 2009). On the one hand, as we showed in our first research, the size of the illness drawn also indicates the subjective importance of the illness, its role in the current living environment. According to the results of the present study, the illness perception of the cancer patients in the study showed a very heterogeneous picture, which is indicated by the large variance in the size of the illness circle (IPM). The majority of patients drew their illness 
smaller than the circle symbolizing their self, suggesting a favorable picture of illness in terms of fighting the illness. On the other hand, a circle of illness larger than the self of the person, which largely dominates the actual life, must be interpreted as a sign of attention.

On the other hand, in most of the post-tests of the illness circle, we can find response content indicating illness perception. The most common response rate was illness as a sing / change (31.5\%), which can be considered as particularly favorable for combating the illness. Another positive category of interpretation was the interpretation of illness as a task to be solve (18.5\%). Interpretation of the illness as an obstacle / difficulty was a less positive, although very common response category (25.9\%). Respectively, interpretations of illness as loss (7.4\%), hit (5.55\%), failure $(5.55 \%)$ also appeared, which also reveal a negative perception of illness. A slightly more favorable, albeit more careful, interpretation was to experience the illness as a struggle (5.55\%). The above results are consistent with research using quantitative techniques that challenge is the most common illness interpretation category in cancer patients (Karen et al., 1996; Lesley et al., 2003; Wallberg et al., 2003; Büssing \& Fischer, 2009); and in chronic patients, adverse Interruption of life (Büssing \& Surzykiewicz, 2015).

A further advantage of the test is that it allows us to get a picture not only of the representations of the illness but also of the outcome of the illness. On the one hand, in the answers of the posttest for the illness scope, we can also find the answer contents indicating this (16\%). In the majority of these responses, patients reported positive changes related to the illness. On the other hand, $13 \%$ of the respondents, after drawing the illness circle, presented the recovery with a distinct circle in the free representation part of the test, which indicates its subjective importance, its current presence in mental representations, the thinking about it. Based on the responses to the post-test (What does the recovery represent in your life?) recovery appeared as a value, goal, faith, desire, or miracle in patient representations.

Several respondents also presented their health in a separate circle (14.6\%), which should also be interpreted as positive. In post-test responses, health as a value, life, happiness, or goal response content is indicated. In our view, exploring representations of illness outcome is an important part of recovery work, as research has shown that living with an uncontrollable, unpredictable, and unchangeable illness has more negative outcomes (Evers et al., 2001). Positive representations of recovery, on the other hand, are associated with more favorable outcomes (Mondloch, Cole \& Frank, 2001). 
In summary, the results of the STUDY 2 showed that the PRISM-D and its post-test are suitable to measure the illness-related representations and reactions of cancer patients. The PRISM-D provides complex quantitative and qualitative information easily and quickly, which allows for various possibilities during the data analysis. In our opinion, the application of this test version is beneficial both in clinical practice and for research purposes.

As a third step of the research, in STUDY3, the aim was to investigate whether the PRISM-D test is suitable for measuring perceived social support. The starting point of the research was the results of the method validation research of the PRISM-D test related to social support. In the third study, a more differentiated examination of social support displayed on the PRISM test was performed, analyzing the PRISM-D, STAI, and BDI tests of 194 severe hospital patients (cancer, chronic renal insufficiency gastro-intestinal disease patients).

According to our results, in the PRISM-D test, after drawing the illness circle, the majority of patients $(95.7 \%)$ displayed their family or its members during free imaging. In sum, $72.7 \%$ of them also drew other social support persons, e.g., friends, colleagues, neighbors. The majority of patients drew social support with multiple circles (64\%).

However, $4.3 \%$ of patients did not show a social support person at all on the test, which we interpret may indicate perceived social isolation. And our further results suggest that individuals who did not enroll in social support had higher trait and anxiety scores than those who indicated at least one individual. However, there was no detectable relationship between the number of circles symbolizing social support persons displayed on the PRISM-D test and anxiety. So perceived isolation seems to be related to experiencing more unfavorable anxiety, the number of relationships is irrelevant in this regard, the point is to be a person that the patient perceives within their current social environment.

In our opinion, the above result draws attention to the fact that, in contrast to the PRISM + tests, it was worthwhile to allow free, unrestricted representation, as it can also be very informative what patients do not draw. It should be emphasized that the test may measure the perceived isolation at the time of test recording and not the number of connections actually present. It is important to note that in severe patients, lived isolation often does not mean that the person has no social connections at all, but in many cases the mental processes resulting from the illness, e.g. unable to mobilize these potential resources due to narrowed focus on the illness or its 
treatment. However, our results suggest that this type of representation is definitely worth noting as a sign of attention, as according to previous research, perceived social isolation affects health outcomes negatively (Cacioppo \& Hawkley, 2003).

The spatial location of the social support factors drawn in the test provides interesting information. According to our results, the distance of the social support circle drawn closest to the self circle from the self is significantly related to the illness perception measure (IPM, which is determined based on the size of the illness). The result suggests that individuals who felt closer to social support reported their illness as smaller, i.e., presumably felt less, suggesting a more favorable perception of the illness. The above result is consistent with literature data suggesting that members of the social support environment play a role in shaping the image of the illness (Benyamini, Medalion \& Garfinkel, 2007; Guzman \& Nicassio, 2003). Illnessrelated views and representations, in turn, are associated with a number of health-related outcomes based on research findings (Hagger \& Orbell, 2003; Petire, Jago \& Devcich, 2007). Thus, social support can also indirectly influence patients' health indicators through its impact on the image of the illness.

Our further results suggest that the relative positions of the self, illness, and social support may also be very informative. This is because individuals who drew illness closer to the circle symbolizing the self and social support experienced a significantly higher level of anxiety and depression than those who drew social support between the circle of illness and the self circle. This result is consistent with the stress buffer theory of social support, which states that social support exerts its beneficial effects by enabling to buffer distress (Theory on Stress Buffering; Cohen \& Wills, 1985; Thoits, 1982), which in this case may be caused by the illness. In the PRISM-D test, the depiction of the relationship between the self, illness, and social support, and its relationship to the level of anxiety, roughly visualizes the essence of the above theory.

Overall, our above findings that there is a relationship between social support and anxiety and depression levels are related to literature data (Procidano, 1992; Sarason BR, Sarason IG, Gurung, 1997; Lin, Ye \& Ensel, 1999; Lakey \& Cronin, 2008). This, in turn, confirms that this novel visual measurement tool is also able to show the correlations of longer, more timeconsuming paper-pencil tests, which require more energy from patients.

It is important to note that in the PRISM-D test, the circles drawn in the person's current living environment, symbolizing social support, only reveal their current perception; however, they 
do not provide any information about the amount and the potential availability of this support, and whether or not the support was really used. The clarifying question of the post-test (what the given factor means to the patient) may provide an answer to these, but the purpose of the test is not to examine the above dimensions in detail.

It is an advantage of the PRISM-D test that, as it is a projective procedure, it helps to reveal the subjective, less conscious elements of perceived social support. It can help raise awareness of social resources that the patient can make little or no use of, which can be a starting point in therapeutic work to help the patient seek help and use social support. In therapeutic work, the psychologist can also help patients recognize that both healing professionals and fellow patients are present as potential supportive people in their current living environment. It can help to initiate communication with them, to formulate needs and requests adequately.

In summary, the PRISM-D test makes it easy and quick to explore patients' subjectively perceived social support, its relationship to illness and the Self, and its subjectively perceived place within the current living environment. It is suitable for screening the subjectively experienced social isolation and the difficulty of activating social relationships. In our opinion, the test is especially useful in the clinical setting, as it allows professionals to make a relatively quick analysis, as it shows the social network currently perceived by the patient, its size and location in relation to the disease and the Self.

Because the test is easy and quick to apply, it can be taken over and over again, so changes in the social support environment (weakening and strengthening of relationships) can be detected, mely további előnyt jelent a kliniai alkalmazás során. 


\section{CONCLUSIONS}

The aim of the drawing test version developed by our research group was to combine the advantages of projective drawing tests and PRISM tests, to create a measuring tool that is understandable, easy and quick to use for everyone, while providing differentiated information. Our results suggest that the new visual procedure can be used in a wide range of somatic patients under hospital treatement, even in patients with difficult verbal communication. The drawing test version does not require special tools, the test instructions are easy for patients to understand, the data collection is fast, it does not burden the patients, thus it fits well into the clinical environment. At the same time, it can be used to gather extremely rich information about the individual's experience of the illness and his or her role in a person's life.

Based on the results of our research, the PRISM-D drawing test, as well as sample previous PRISM tests, is suitable for measuring illness suffering and illness perception. The freely visualization provided by the drawing, as well as the post-test related to the test, provide an additional set of information that can be analyzed from a great deal of perspectives. According to our results, PRISM-D differentially measures the relationship between the self and illness, illness-related cognitions, emotional and cognitive representations, and resources and barriers that potentially support recovery. It is also suitable for detecting perceived social support and perceived social isolation.

The measuring device is able to capture the uniqueness of the patients, the subjective representations at the same time, but it is also suitable for collecting statistically analyzable data and for performing comparative studies on a large sample. The data obtained from the test allow for either quantitative or qualitative analysis.

Based on our research and clinical experience, the PRISM-D test and its post-test can be used well as a screening test during clinical health psychology activities, as well as for the detection of reactions that need to be further investigated from a clinical point of view. It may be suitable for identifying, among other things, suffering from extremely severe illness, negative perception of illness, illness denial, lack of resources, perceived social isolation, and factors that may hinder recovery. The detection of individual spatial representation features even allows the practitioner a quick analysis, which can be useful during the clinical work. At the same time, the recorded tests can be analyzed in detail at a later stage, even together with the patient, if further joint work is required. 
In our clinical experience, taking the PRISM-D test alone has benefits for patients. Based on the fact that projective drawing tests examining illness perception have shown that they can help patients share emotions, experiences, and thoughts about the illness that are difficult to verbalize, and that patients can better understand themselves (Cheung, Saini \& Smith, 2016), in our opinion the PRISM-D's schematic drawing task can also provide similar benefits to patients. However, in the case of PRISM-D, there is no need to anticipate that patients' drawing talent may influence the interpretation of drawings. Since patients may have drawn not only their illness but also other factors of their living environment that are important to them, as Sensky and Büchi (2016) emphasized in connection with previous PRISM tests, PRISM-D can also help patients having such a visual summary look at their current life situation, which may have therapeutic effects in itself. It also provides an opportunity for the patient to think about what changes they want to make compared to the current image.

During psychological intervention work, at the beginning of therapeutic work, PRISM-D can help with individualized, targeted information gathering, the establishment of a therapeutic relationship, and the development of a therapeutic plan. As a therapeutic tool, similar to previous PRISM tests (Streffer et al., 2009), it can help patients reflect on their own situation as well as facilitate verbal communication. In our opinion, the PRISM-D test, similar to previous PRISM tests (Sensky \& Büchi, 2016), is also suitable for individual and group work. From a therapeutic point of view, the advantage of the nature of the drawing test is the preservation of the tests, the patients can even take it with them or take it out again and again during the therapy. Furthermore, the recording of the PRISM-D test can be repeated, thus providing an opportunity to track the patient's condition change.

Overall, the PRISM-D drawing test, retaining the values of previous PRISM tests and further developing it, is an excellent method with a simpler tool requirement that can be used in both clinical practice and research. It allows for quantitative and qualitative analysis that could be used for screening, quantitative follow-up of changes, and research among a wide range of somatic patients under hospital treatment. 


\section{ACKNOWLEDGEMENTS}

I would like to express my sincere gratitude to my supervisor, Professor Márta Csabai for her endless support and guidance in carrying out my research. I am grateful to Dr. Melinda Látos, Dr. Andrea Homoki and Kristóf Czinderi for the continuous professional and friendly support. I am also thank Petra Pócza-Véger, Rózsa Havancsák ${ }^{\dagger}$ and Dr. Peter Kovács for the help with the data collection.

I wish to express my sincere appreciation thank to the leadership and the community of the Gál Ferenc University that they support. I am also greatful the leadership of the Pándy Kálmán Member Hospital of the Békés County Central Hospital, especially Dr. László Becsei for the support of the study implementation, and the leadership and community of the General Surgery Division, especially Dr. Aurél Ottlakán the support of the data collection, and Dr. Attila Bartóki for the friendly and professional support in the first steps of our research.

I would like to thank the further clinical centers where the data collection was conducted for their support. I am also thankful to the patients who participate in our studies.

I would like to thank my family for encouragement and endless support. 


\section{REFERENCES}

1. Adler N, Matthews K. Health Psychology. Who do some people det sick and some stay well? Annu Rev Psychol. 1994;45:229-259.

2. Alferi SM, Carver CS, Antoni MH, Weiss S, Durán RE. An exploratory study of social support, distress, and life disruption among low-income hispanic women under treatment for early stage breast cancer. Health Psychol. 2001;20(1):41-46.

3. Anagnostopoulos F, Spanea E. Assessing illness representations of breast cancer. A comparison of patients with healthy and benign controls. $\mathrm{J}$ of Psychosom Res. 2005;58:327-334.

4. Andersen BL, Farrar WB, Golden-Kreutz D, Emery CF, Glaser R, Crespin T, et. al. Distress reduction from a psychological intervention contributes to improved health for cancer patients. Brain Behav Immun. 2007;21(7):953-961.

5. Arpin K, Fitch M, Browne BB, Corey P. Prevalence and correlates of family dysfunction and poor adjustment to chronic illness in specialty clinics. J Clin Epidemiol. 1990;43:373-383.

6. Barrera M. Social support research in community psychology. In: Rappaport J, Seidman E, editors. Handbook of community psychology. New York, New York, USA: Kluwer Academic/Plenum; 2000. p. 215-245.

7. Beck AT, Ward CH, Mendelson M, Ock J, Erbaugh J. An inventory for measuring depression. Arch Gen Psychiatry. 1960;4:561-571.

8. Benyamini Y, Medalion B, Garfinkel D. Patient and spouse perceptions of the patient's heart disease and their associations with received and provided social support and undermining. Psychol Health. 2007;22:765-785.

9. Berkanovic E, Hurwicz ML. Rheumatoid arthritis and comorbidity. J Rheumatol. 1990;17:888-892. 
10. Broadbent E, Ellis CJ, Gamble G, Petrie KJ. Changes in patient drawings of the heart identify slow recovery after myocardial infarction. Psychosom Med. 2006;68(6):910913.

11. Broadbent E, Ellis CJ, Thomas J, Gamble G, Petrie KJ. Can an illness perception intervention reduce illness anxiety in spouses of myocardial infarction patients? A randomized controlled trial. J Psychosom Res. 2009;67:11-15.

12. Broadbent E, Niederhoffer K, Hague T, Corter A, Reynolds L. Headache sufferers' drawings reflect distress, disability and illness perceptions. J Psychosom Res. 2009;66(5):465-70.

13. Broadbent E, Petrie KJ, Alley PG, Booth RJ. Psychological stress impairs early wound repair following surgery. Psychosom Med. 2003;65:865-869.

14. Broadbent E, Petrie KJ, Ellis CJ, Ying J, Gamble G. A picture of health -myocardial infarction patients' drawings of their hearts and subsequentdisability: a longitudinal study. J Psychosom Res. 2004;57(6):583-587.

15. Broadbent E, Petrie KJ, Main J, Weinman J. The Brief Illness Perception Questionnaire. J Psychosom Res. 2006;60:631-637.

16. Broadbent E, Schoones JW, Tiemensma J, Kaptein AA. A systematic review of patients' drawing of illness: implications for research using the Common Sense Model, Health Psychol Rev. 2019;13(4):406-426.

17. Brummet BH, Mark DB, Siegler IC, Williams RB, Babyak MA, Clapp-Channing NE, et al. Perceived social support as a predictor of mortality in coronary patients: effects of smoking, sedentary behaviour, and depressive symptoms. Psychosom Med. 2005;67:4045.

18. Büchi S, Buddeberg C, Klaghofer R, Russi EW, Brändli O, Schlösser C, et al. (2002). Preliminary validation of PRISM (Pictorial Representation of Illness and Self Measure) — a brief method to assess suffering. Psychother Psychosom. 2002;71(6):333341. 
19. Büchi S, Mörgeli H, Schnyder U, Jenewein J, Glaser A, Fauchère J-C, et al. Shared or discordant grief in couples 2-6 Years after the death of their premature baby: effects on suffering and posttraumatic growth. Psychosomatics.2009;50(2):123-30.

20. Büchi S, Sensky T, Sharpe L, Timberlake N. Graphic representation of illness: a novel method of measuring patients' perceptions of the impact of illness. Psychother Psychosom. 1998;67:222-225.

21. Büchi S, Sensky T. PRISM: Pictorial Representation of Illness and Self Measure. A brief nonverbal measure of illness impact and therapeutic aid in psychosomatic medicine. Psychosomatics. 1999;40(4):314-320.

22. Büchi S, Villiger P, Kauer Y, Klaghofer R, Sensky T, Stoll T. PRISM (Pictorial Representation of Illness and Self Measure): a novel visual method to assess the global burden of illness in patients with systemic lupus erythematosus. Lupus, 2000;9(5):368373.

23. Büssing A, Fischer J. Interpretation of illness in cancer survivors is associated with health-related variables and adaptive coping styles. BMC Womens Health. 2009;9(2):111.

24. Büssing A, Ostermann T, Neugebauer E, Heusser P. Adaptive coping strategies in patients with chronic pain conditions and their interpretation of disease. BMC Public Health. 2010;10:507.

25. Büssing A, Surzykiewicz J. Interpretation of illness in patients with chronic diseases from Poland and their associations with spirituality, life satisfaction, and escape from illness - results from a cross sectional study. Religions. 2015;6:763-780.

26. Cacioppo JT, Hawkley LC. Social isolation and health, with an emphasis on underlying mechanisms. Perspect Biol Med. 2003;46(3 Suppl):S39-S52.

27. Cameron LD, Leventhal H. The self-regulation of health and illness behavior. London, England: Routledge; 2003. 
28. Cardol M, Groenewegen PP, de Bakker DH, Spreeuwenberg P, van Dijk L, van den Bosch W. Shared help seeking behaviour within families: a retrospective cohort study. BMJ. 2005;3:882-884.

29. Caress A, Luker KA, Owens RG. A descriptive study of meaning of illness in chronic renal disease. J Adv Nurs. 2011;33:716-27.

30. Carlson LE, Angen M, Cullem J, Goodey E, Koopmans J, Lamont L, et al. High levels of untreated distress and fatigue in cancer patients. Br J Cancer 2004;90:2297-2304.

31. Carver CS, Pozo C, Harris SD, Noriega V, Scheier MF, Robinson DS, et al. How coping mediates the effect of optimism on distress: A study of women with early stage breast cancer. J Pers Soc Psy. 1993;65(2):375-390.

32. Cassell EJ. Diagnosing suffering: a perspective. Ann Intern Med. 1999;131(7):531-534.

33. Cassell EJ. The nature of suffering and the goals of medicine. New York, USA: Oxford University Press; 2004.

34. Cherrington CC, Moser DK, Lennie TA, Kennedy KW. Illness representations after acute myocardical infarction: Impact in in-hospital recovery. Am J Crit Care. 2004;12(2):136-145.

35. Cheung MMY, Saini B, Smith L. Using drawings to explore patients' perceptions of their illness: a scoping review. J Multidiscip Healthc. 2016;9:631-646.

36. Cohen S, Wills TA. Stress, social support, and the buffering hypothesis. Psychol Bull. 1985;98:310-357.

37. de Ridder D, Geenen R, Kuijer R, van Middendorp H. Psychological adjustment to chronic disease. The Lancet. 2008;372:246-255.

38. Dempster M, Howell D, McCorry NK. Illness perceptions and coping in physical health conditions: A meta-analysis. J Psychosom Res. 2015;79(6):506-513.

39. Dong ST, Butow PN, Tong A, Agar M, Boyle F, Forster BC, et al. Patients' experiences and perspectives of multiple concurrent symptoms in advanced cancer: a semi-structured interview study. Suppor Care Cancer. 2016;24:1373-1386. 
40. Evers AW, Kraaimaat FW, van Lankveld W, Jongen PJ, Jacobs JW, Bijlsma JW. Beyond unfavorable thinking: the illness cognition questionnaire for chronic diseases. J Consult Clin Psychol. 2001;69(6):1026-1036.

41. Fallowfield LJ, Hall A, Maguire P, Baum M, A’Hern RP. Psychological effects of being offered choice of surgery for breast cancer. BMJ. 1994;309:448-448.

42. Fitzpatrick R, Newman S, Lamb R, Shipley M. Social relationships and psychological well-being in rheumatoid arthritis. Soc Sci Med.1988; 27:399-403.

43. Frisch Michael B. Quality of life therapy: Applying a life satisfaction approach to positive psychology and cognitive therapy. New Jersey, USA: John Wiley \& Sons, Hoboken; 2005.

44. Gielissen MF, Prins JB, Knoop H, Verhagen S, Bleijenberg G. Pictorial Representation of Self and Illness Measure (PRISM): a graphic instrument to assess suffering in fatigued cancer survivors. Psychol Assess. 2013;25:658-663.

45. Gigliotti EA. Confirmation of the factor structure of the Norbeck Social Support Questionnaire. Nurs Res. 2002;51(5):276-284.

46. Groleau D, Young A, Kirmayer LJ. The McGill Illness Narrative Interview (MINI): an interview schedule to elicit meanings and modes of reasoning related to illness experience. Transcult Psychiatry. 2006;43(4):671-691.

47. Guzman SJ, Nicassio PM. The contribution of negative and positive illness schemas depression in patients with end-stage renal disease. J Behav Med. 2003; 26: 517-534.

48. Hagger M, Orbell S. A meta-analytic review of the common-sense model of illness representations. Psychol Health. 2003;18:141-184.

49. Hampson SE, Glasgow RE. Toobert DJ. Personal models of diabetes and their relations to self-care activities. Health Psychol. 1990;9(5):632-646.

50. Hartmann M, Bäzner E, Wild B, Eisler I, Herzog W. Effects of interventions involving the family in the treatment of adult patients with chronic physical diseases: A metaanalysis. Psychother Psychosom. 2010;79:136-148. 
51. Havancsák R, Pócza-Véger P, Csabai M. (2013) A PRISM-D rajzteszt kórházi betegek vizsgálatában. In: Csabai M, Pintér J. N, editors. Pszichológia a gyógyításban. Budapest: Oriold és Társai Kiadó; 2013. p. 83-107.

52. Higginson IJ, Carr AJ. Measuring quality of life: using quality of life measures in the clinical setting. BMJ. 2001;322(7297):1297-300.

53. Holahan CJ, Moos RH, Holahan CK. Brennan PL. Social context, coping strategies, and depressive symptoms: an expanded model with cardiac patients. J Pers Soc Psycho. 1997;72:918-928.

54. Horne R, Weinman J, Hankins M. The beliefs about medicines questionnaire: the development and evaluation of a new method for assessing the cognitive representation of medication. Psychol Health. 1999;14(1):1-24.

55. Johnston M. Impending surgery. In: Fisher S, Reason J, editors. Handbook of life stress, cognition and health. New York, New York, USA: Wiley; 1998. p. 79-100.

56. Juergens MC, Seekatz B, Moosdorf RG, Pertie KJ, Rief W. Illness beliefs before cardic surgery predict disability, quality of life, and depression 3 months later. J Psychosom Res. 2009;68(6):553-60.

57. Kahn DL, Steeves RH. The significance of suffering in cancer care. Semin Oncol Nurs. 1995;11(1)9-16.

58. Kaplan BH, Cassel JC, Gore S. Social support and health. Med Care. 1997;15:47-58.

59. Kaptein AA, Broadbent E. Illness cognition assessment. In Ayers S, Baum A, McManus C, Newman S, Wallston K, Weinman J, et al. editors. Cambridge Handbook of Psychology, Health and Medicine. New York, New York, USA: Cambridge University Press; 2007. p. 268-272.

60. Kaptein AA, Zandstra T, Scharloo M, Vogel JJ, Broadbent E, Hughes BM, et al. "A time bomb ticking in my head": drawings of inner ears by patients with vestibular schwannoma. Clin Otolaryngol. 2011;36(2):183-184. 
61. Kassardjian CD, Gardner-Nix J, Dupak K, Barbati J, Lam-McCullock J. Validating PRISM (Pictorial Representation of Illness and Self Measure) as a measure of suffering in chronic non-cancer pain patients. J Pain. 2008;9.1135-1143.

62. Kehlet H. Multimodal approach to control postoperative pathophysiology and rehabilitation. Br J Anaesth. 1997;78:606-617.

63. Kemeny ME. Gruenewald TL. Affect, cognition, the immune system and health. Prog Brain Res. 2000;122:291-308.

64. Kiecolt-Glaser JK, Page GG, Marucha PT, MacCallum RC, Glaser, R. Psychological influences on surgical recovery perspectives from psychoneuroimmunology. Am Psychol. 1998;53(11):1209-1218.

65. Klis S, Vingerhoets AJ, de Wit, Zandbelt N, Snoek FJ. Pictorial Representation of Illness and Self Measure Revised II (PRISM-RII): a novel method to assess perceived burden of illness in diabetes patients. Health Qual Life Outcomes. 2008;6:104.

66. Koenigsmann M, Koehler K, Regner A, Franke A, Frommer J. Facing mortality: A qualitative in-depth interview study on illness perception, lay theories and coping strategies of adult patients with acute leukemia 1 week after diagnosis. Leuk Res. 2006;30(9):1127-1134.

67. Kreitler S. Denial in cancer patients. Cancer Invest. 1999;17(7): 514-534.

68. Krikorian A, Limonero JT, Román JP, Vargas JJ, Palacio C. Predictors of suffering in advanced cancer. Am J Hosp Palliat Care. 2014;31(5):534-542.

69. Krikorian A, Limonero JT, Vargas JJ, Palacio C. Assessing suffering in advanced cancer patients using Pictorial Representation of Illness and Self-Measure (PRISM), preliminary validation of the Spanish version in a Latin American population. Support Care Cancer. 2013;21(12):3327-3336.

70. Krikorian A, Limonero JT. An integrated view of suffering in palliative care. J Palliat Care. 2012;28(1):41-49.

71. Krohne W, Slangen K. Influence of social support on adaptation to surgery. Health Psychol. 2005;24:101-105. 
72. Lacroix JM, Martin B, Avendano M, Goldstein R. Symptom schemata in chronic respiratory patients. Health Psychol. 1990;10(4):268-273.

73. Lacroix JM. Assessing illness schemata in patient populations. In: Skelton JA, Croyle RT, editors. Mental representation in health and illness. New York, New York, USA: Springer Verlag; 1991. p. 193-219.

74. Lakey B, Cronin A. Low social support and major depression: Research, theory and methodological issues. In: Dobson KS, Dozois D, editors. Risk factors for depression. San Diego, CA, USA: Academic Press; 2008. p. 385-408.

75. Lakey B, Drew JB. A social-cognitive perspective on social support. In: Pierce GR., Lakey B, Sarason IG, et al, editors. Sourcebook of theory and research on social support and personality. New York, New York, USA: Plenum; 1997. p. 107-140

76. Látos M, Barabás K, Lázár G, Szederkényi E, Szenohradszky P, Marofka F, et al. Mental representations of the new organ and posttransplant patients' anxiety as related to kidney function. Transplant Proc. 2012 Sep;44(7):2143-2146.

77. Lauwerier' E, Crombez G, Damme S, Goubert L, Vogelaers D, Evers AW. The construct validity of the Illness Cognition Questionnaire: The robustness of the three-factor structure across patients with chronic pain and chronic fatigue. Int J Behav Med. 2010;17(2):90-96.

78. Lehmann V, Oerlemans S, van de Poll-Franse LV, Vingerhoets AJ, Mols F. Suffering in long-term cancer survivors: an evaluation of the PRISM-R2 in a population-based cohort. Qual Life Res. 2011;20(10):1645-1654.

79. Lesley F. Degner, Thomas Hack, John O’Neil, and Linda J. Kristjanson. “A new approach to eliciting meaning in the context of breast cancer." Cancer Nursing 26 (2003): 169-78.

80. Leventhal H, Leventhal EA, Cameron L. Representations, procedures, and affect in illness self-regulation: a perceptual-cognitive model. In: Baum A, Revenson TA, Singer JE, editors. Handbook of Health Psycholog. Mahwah, NJ, USA: Lawrence Erlbaum; 2001. p. 19-47. 
81. Leventhal H, Meyer D, Nerenz DR. The Common sense representation of illness danger. In: Rachman S, editor. Contributions to Medical Psychology. New York, New York, USA: Pergamon Press; 1980. p. 17-30.

82. Lima-Verde AC, Pozza DH, Rodrigues LL, Velly AM, Guimaraes AS. (2013). Crosscultural adaptation and validation for Portuguese (Brazilian) of the Pictorial Representation of Illness and Self Measure instrument in orofacial pain patients. J Orofac Pain, 2013;27:271-275.

83. Lin N, Ye X, Ensel W. Social support and depressed mood: A structural analysis. J Health Soc Behav. 1999;40:344-359.

84. Lipowski ZJ. Physical illness, the individual and the coping processes. Psychiatry Med. 1970;1(2):91-102.

85. Lipowski ZJ: Psychosocial reactions to physical illness. Can Med Assoc J. 1983;128:1069-1072.

86. Livneh H, Antonak RF. Psychosocial adaptation to chronic illness and disability: A primer for counselors. J Couns Dev. 2005;(83):12-20.

87. Luker KA, Beaver K, Leinster SJ, Owens RG. Meaning of illness for women with breast cancer. J Adv Nurs 1996;23:1194-201.

88. Martire LM, Schulz R, Helgeson VS, Small BJ, Saghafi, EM. Review and meta-analysis of couple-oriented interventions for chronic illness. Ann Behav Med. 2010;40:325-342.

89. Marucha PT, Kiecolt-Glaser JK, Favagehi M. Mucosal wound healing is impaired by examination stress. Psychosom Med. 1998;60(3):362-365.

90. Mathews A, Ridgeway V. Persoanality and surgical recovery: A review. Br J Clin Psychol. 1981;20:243-260.

91. McGregor BA, Antoni MH. Psychological intervention and health outcomes among women treated for breast cancer: A review of stress pathways and biological mediators. Brain Behav Immun. 2009:23;259-166. 
92. Meyer M, Luethi MS, Neff P, Langer N, Büchi S. Disentangling tinnitus distress and tinnitus presence by means of EEG power analysis. Neural Plast. 2014:1-13.

93. Molloy GJ, Johnston DW, Witham MD. Family caregiving and congestive heart failure: review and analysis. Eur J Heart Fail. 2005;7:592-603.

94. Mondloch MV, Cole DC, Frank JW. Does how you do depend on how you think you'll do? A systematic review of the evidence for a relation between patients' recovery expectations and health outcomes. CMAJ. 2001;165(2):174-179.

95. Moss-Morris R, Weinman J, Petrie KJ, Horne R, Cameron LD, Buich D. The Revised Illness Perception Questionnaire (IPQ-R). Psychol Health. 2002;17(1): 1-16.

96. Murtagh FE, Addington-Hall J, Higginson IJ. The prevalence of symptoms in endstage renal disease: a systematic review. Adv Chronic Kidney Dis. 2007;14(1):8299.

97. Mühleisen B, Büchi S, Schmidhauser S, Jenewein J, French LE, Hofbauer GL. Pictorial Representation of Illness and Self Measure (PRISM): A novel visual instrument to measure quality of life in dermatological inpatients. Arch Dermatol. 2009;145(7):774780.

98. Norbeck JS, Lindsey AM, Carrieri VL. Further development of the Norbeck Social Support Questionnaire: Normative data and validity testing. Nurs Res. 1983;32(1):4-9.

99. Norbeck JS, Lindsey AM, Carrieri VL. The development of an instrument to measure social support. Nurs Res. 1980;30(5):264-269.

100.Noyes RJ, Holt C, Massie M. Anxiety disorders. In: Holland JC, editor. Psychooncology New York, New York, USA: Oxford University Press; 1995. p. 548-563.

101.Pandit AU, Bailey SC, Curtis LM, Seligman HK, Davis TC, Parker RM, et al. Diseaserelated distress, self-care and clinical outcomes among low-income patients with diabetes. J Epidemiol Community Health. 2014;68(6):557-564.

102.Patel SS, Peterson RA, Kimmel PL. The impact of social support on end-stage renal disease. Semin Dial. 2005; 18: 98-102. 
103.Penninx BW, van Tilburg T, Boeke AJ, Deeg DJ, Kriegsman DM, van Eijk JT. Effects of social support and personal coping resources on depressive symptoms: Different for various chronic diseases? Health Psychol. 1998;17:551-558.

104.Pertie KJ, Jago LA, Devcich DA. The role of illness percepcion in patients with medical conditions. Cur Opin Psychiatry. 2007;20:163-167.

105.Peter N, Kleinjung T, Horat L, Schmidt-Weitmann, Meyer M, Büchi S, et al. Validation of PRISM (Pictorial Representation of Illness and Self Measure) as a novel visual assessment tool for the burden of suffering in tinnitus patients. Health Qual Life Outcomes. 2016;14(47):1-9.

106.Petrie K, Weinman J. Patients' perceptions of their illness: The dynamo of volition in health care. Int J Emerg Ment Health. 2012;12:41-50.

107.Petrie KJ, Camerin LD, Ellis CJ, Buick D, Weinman J. Changing illness perceptions after myocardial infarction: An early intervention randomized controlled trial. Psychosom Med. 2002;64:580-586.

108.Petrie KJ, Weinman J, Shape N, Buckley J. Role of patients' view of their illness in predicting return to work and functioning after myocardial infarction: Longitudinal study. BMJ. 1996;312(7040):1191-1194.

109.Procidano ME. The nature of perceived social support: Findings of meta-analytic studies. In: Spielberger CD, Butcher JN, editors. Advances in personality assessment. Hillsdale, NJ, USA: Erlbaum; 1992. p. 1-26.

110.Reblin M, Uchino BN. Social and emotional support and its implication for health. Curr Opin Psychiatry. 2008;21:201-205.

111.Reimus JL, Vingerhoets AJ, Soons PH, Korstanje MJ. (2007). Suffering in psoriasis patients: its relation with illness severity and subjective well-being. Int J Dermatol. 2007;46:1042-1045.

112.Reynolds L, Broadbent E, Ellis CJ, Gamble G, Petrie KJ. Patients' drawings illustrate psychological and functional status in heart failure. J Psychosom Res. 2007;63(5).525532. 
113.Richter P, Werner J, Heerlein A, Kraus A, Sauer H. On the validity of the Beck Depression Inventory: A review. Psychopathology. 1998;31:160-168.

114.Rokach A. Correlates of loneliness as perceived by the terminally ill. Curr Psychol. 2000;19:237-248.

115.Rokach A. Correlates of loneliness as perceived by the terminally ill. Curr Psychol. 2000;19:237-248.

116.Rózsa S, Szádóczky E, Füredi J. A Beck Depresszió Kérdőív rövidített változatának jellemzői hazai mintán. Psychiatria Hungarica. 2001;16:384-402.

117.Rumpf HJ, Lontz W, Uesseler S. A self-administered version of a brief measure of suffering: first aspects of validity. Psychother Psychosom. 2004;73:53-56.

118.Sararoudi RB, Motmaen M, Maracy MR, Pishghadam E, Kheirabadi GR. Efficacy of illness perception focused intervention on quality of life, anxiety, and depression in patients with myocardial infarction. J Res Med Sci. 2016;21:125.

119.Sarason BR, Sarason IG, Gurung RAR. Close personal relationships and health outcomes: A key to the role of social support. In: Duck S, editor. Handbook of personal relationships. New York, New York, USA: Wiley; 1997. p. 547-573.

120.Sarason IG, Levine HM, Basham RB, Sarason BR. Assessing social support: The Social Support Questionnaire. J Pers Soc Psychol. 1983;44(1):127-139.

121.Scott-Sheldon LAJ, Kalichman SC, Carey MP, Fielder RL. Stress management interventions for HIV+ adults: A meta-analysis of randomized controlled trials 1989 to 2006. Health Psychol. 2008;27(2):129-139.

122.Sensky T, Büchi S. PRISM, A novel visual metaphor to measure personally salient appraisals, attitudes and decision-making: qualitative evidence synthesis. PLoS One, 2016;11(5):1-18.

123. Shumaker SA, Naughton MJ. The international assessment of health-related quality of life: a theoretical perspective. In: Shumaker SA, Berzon R, editors. The international assessment of health-related quality of life: Theory, translation, measurement and analysis. Oxford, United Kingdom: Rapid Communications; 1995. p. 3-10. 
124.Siegert RJ, Patten MD, Walkey FH. Development of a Brief Social Support Questionnaire. N Z J Psychol. 1987;16(2):79-83.

125.Sipos K, Sipos M. The development and validation of the hungarian form of the STAI. In: Spielberger CD, Diaz-Guerrero R, editors. Cross-Cultural Anxiety. Washington, DC, USA: Hemisphere Publishing Corporation; 1978. p. 51-61.

126.Spiegel D. Mind matters - Group therapy and survival in breast cancer. N Engl J Med. 2001;345:1767-1768.

127.Spielberger CD, Gorsuch RL. Lushene RE. Manual for the state-trait anxiety inventory. Palo Alto, CA, USA: Consulting Psychologists Press; 1970.

128.Stansfeld S, Marmot M. Deriving a survey measure of social support: The reliability and validity of the close persons questionnaire Soc Sci Med; 1992;35(8):1027-1035.

129. Stanton AL, Revenson TA, Tennen H. Health Psychology: Psychological adjustment to chronic disease. Annu Rev Psychol. 2007;58:565-592.

130.Stanton AL, Revenson TA, Tennen H. Health psychology: psychological adjustment to chronic disease. Annu Rev Psychol. 2007; 58:565-592.

131.Stefaniak TJ, Dziedziul J, Walerzak AM, Stadnyk M, Sheikh A, ProczkoMarkuszewska M, et al. Pain intensity and perceived social support among patients with pancreatic tumors. J Pain Relief. 2012;1:110.

132.Stone AA, Mezzacappa ES, Donatone BA, Gonder M. Psychosocial stress and social support are associated with prostate-specific antigen levels in men: Results from a community screening program. Health Psychol. 1999;18:482-486.

133.Streffer ML, Büchi S, Mörgeli H, Galli U, Ettlin D. PRISM (Pictorial Representation of Illness and Self-Measure): a novel visual instrument to assess pain and suffering in orofacial pain patients. J Orofac Pain. 2009;23(2):140-146.

134.Suurmeijer TP, Doeglas PM, Briançon S, Krijnen WP, Krol B, Sanderman R, et al. The measurement of social support in the 'European research on incapacitating diseases and social support': The development of the Social Support Questionnaire for Transactions (SSQT). Soc Sci Med. 1995;40(9):1221-1229. 
135.Teel CS. Chronic sorrow: Analysis of the concept. J Adv Nurs. 1991:16;1311-1319.

136.Telford K, Kralik D, Koch T. Acceptance and denial: implications for people adapting to chronic illness: literature review. J Adv Nurs. 2006;55(4): 457-464.

137.Thoits PA. Conceptual, methodological, and theoretical problems in studying social support as a buffer against life stresses. J Hlth Soc Behav. 1982;23:145-159.

138. Tiemensma J, Daskalakis NP, van der Veen EM, Ramondt S, Richardson SK, Broadbent E, et al. Drawings reflect a new dimension of the psychological impact of long-term remission of Cushing's Syndrome. J Clin Endocrinol Metab. 2012;97(9):3123-3131.

139.Tiemensma J, Pereira AM, Romijn JA, Broadbent E, Biermasz NR, Kaptein AA. Persistent negative illness perceptions despite long-term biochemical 1 control of acromegaly: novel application of the drawing test. Eur J Endocrinol. 2015;172(5):583593.

140.Tjemsland L, Haslerud J, Søreide JA, Malt UF. Measuring social support: An interrater reliability study of 18 patients with breast cancer assessed with a shortened version of the Self-Evaluation and Social Support (SESS) schedule. Nord J Psychiatry. 1994;48(2):97-101.

141.Turner-Cobb JM, Gore-Felton C, Marouf F, Koopman C, Kim P, Israelski D, et al. Coping, social support, and attachment style as psychosocial correlates of adjustment in men and women with HIV/AIDS. J Behav Med. 2002;25:337-353.

142.Uchino BN, Cacioppo JT, Kiecolt-Glaser JK. The relationship between social support and physiological processes: A review with emphasis on underlying mechanisms and implications for health. Psychological Bull. 1996;119:488-531.

143.Uchino BN. Social support and physical health: Understanding the health consequences of our relationships. New Haven, CT, USA: Yale University Press; 2004.

144.Van Stralen G, van Stralen-Ruijten LLM, Spaargaren CF, Broadbent E, Kaptein AA, Scherjon SA. Good quality of life after emergency embolisation in postpartum haemorrhage. J Psychosom Obstet Gynaecol. 2010;31(4):285-288. 
145.Veiel HO. The Mannheim Interview on Social Support: Reliability and validity data from three samples. Soc Psychiatry Psychiatr Epidemiol. 1990;25:250-259.

146.Vogt TM, Mullooly JP, Ernst D, Pope CR, Hollis JF. Social networks as predictors of ischemic heart disease, cancer, stroke and hypertension: incidence, survival and mortality. J Clin Epidemiol.1992;45:659-666.

147.Vos MS. de Haes JC. Denial in cancer patients, an explorative review. Psychooncology. 2007;16(1):12-25.

148.Wallberg B, Michelson H, Nystedt M, Bolund C, Degner L, Wilking N. The meaning of breast cancer. Acta Oncol. 2003;42:30-35.

149.Weinman J, Petrie KJ, Moss-Morris R, Horne R. The illness perception questionnaire: a new method for assessing the cognitive representation of illness. Psychology \& Health, 1996;11(3):431-445.

150.Weinman J, Petrie KJ. Illness percepctions: A new paradigm for psychosomatics? J Psychosom Res. 1997;42(2):113-116.

151.Wills TA, Fegan MF. Social networks and social support In: Baum A, Revenson TA, Singer JE, editors. Handbook of health psychology. Mahwah, NJ, USA: Erlbaum; 2001. p. 209-234.

152.Wills TA, Shinar O. Measuring perceived and received social support. In: Cohen S, Underwood LG, Gottlieb BH, editors. Social support measurement and intervention: A guide for health and social scientists. New York, New York, USA: Oxford University Press; 2000. p. 86-135.

153.Wittmann L, Schnyder U, Büchi S. PRISM (Pictorial Representation of Illness and Self Measure): A new method for the assessment of suffering after trauma. J Trauma Stress. 2012;25(1):94-97.

154.Wouters EJ, Reimus JL, van Nunen AM, Blokhorst MG, Vingerhoets AJ. (2008). Suffering quantified? Feasibility and psychometric characteristics of 2 revised versions of the Pictorial Representation of Illness and Self Measure (PRISM). Behav Med. 2008.34(2):65-78. 
155.Zabora J, BrintzenhofeSzoc K, Curbow B, Hooker C, Piantadosi S. The prevalence of psychological distress by cancer site. Psychooncology. 2001;10:19-28.

156.Zhang Y, Fritzsche K, Leonhart R, Zhao X, Zhang L, Wei J, et al. Dysfunctional illness perception and illness behaviour associated with high somatic symptom severity and low quality of life in general hospital outpatients in China. J Psychosom Res. 2014;77(3):187-195.

157.Zimet GD, Dahlem NW, Zimet SG, Farley GK. The Multidimensional Scale of Perceived Social Support, J Pers Assess. 1988;52(1):30-41.

158.Zimet GD, Powell SS, Farley GK, Werkman S, Berkoff KA. Psychometric characteristics of the Multidimensional Scale of Perceived Social Support. J Pers Assess. 1990;55(3-4):610-617. 


\section{ANNEXES}

Annex 1: PRISM-D test data acquisition protocol

Sex:

Age:

Diagnosis:

Class:

Date of test taking:

Person performing data collection:

\begin{tabular}{|c|c|c|c|c|c|c|}
\hline Order & Color & Size & Distance & Meaning & Special reaction & Post-test \\
\hline 1. & $\begin{array}{c}\text { Red } \\
\text { C-T-O }\end{array}$ & $\begin{array}{l}\mathrm{r}=\longleftarrow \mathrm{cm} \\
\mathrm{a}=\longleftarrow \quad \mathrm{cm}^{2}\end{array}$ & $\mathrm{~d}=\ldots \mathrm{cm}$ & Illness & & \\
\hline 2. & C-T-O & $\begin{array}{l}\mathrm{r}= \\
\mathrm{a}=\end{array} \mathrm{cm}^{2}$ & $\mathrm{~d}=\ldots \mathrm{cm}$ & & & \\
\hline 3. & C-T-O & $\begin{array}{l}\mathrm{r}= \\
\mathrm{a}=\end{array} \mathrm{cm}^{2}$ & $\mathrm{~d}=\ldots \mathrm{cm}$ & & & \\
\hline 4. & C-T-O & $\begin{array}{l}\mathrm{r}= \\
\mathrm{a}=\end{array} \quad \mathrm{cm}$ & $\mathrm{d}=\ldots \mathrm{cm}$ & & & \\
\hline 5. & $\overline{\mathrm{C}-\mathrm{T}-\mathrm{O}}$ & $\begin{array}{l}\mathrm{r}=\longleftarrow \mathrm{cm} \\
\mathrm{a}=\longleftarrow \mathrm{cm}^{2}\end{array}$ & $\mathrm{~d}=\_\mathrm{cm}$ & & & \\
\hline
\end{tabular}

Note: „C" - The test leaders sholud mark this, if the circle is coloured.

„T" - The test leaders sholud mark this, if the circle touching the self circle. 


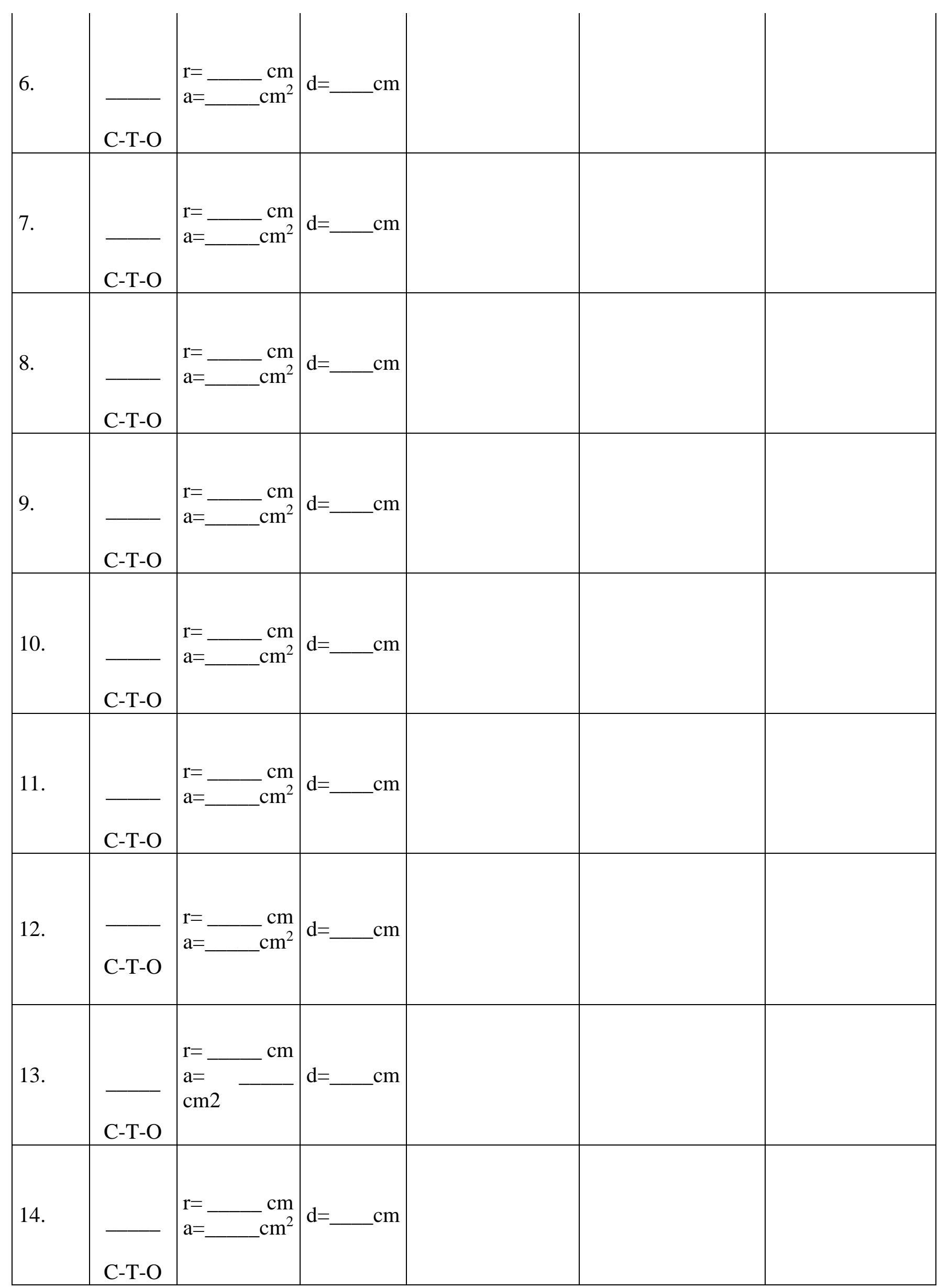




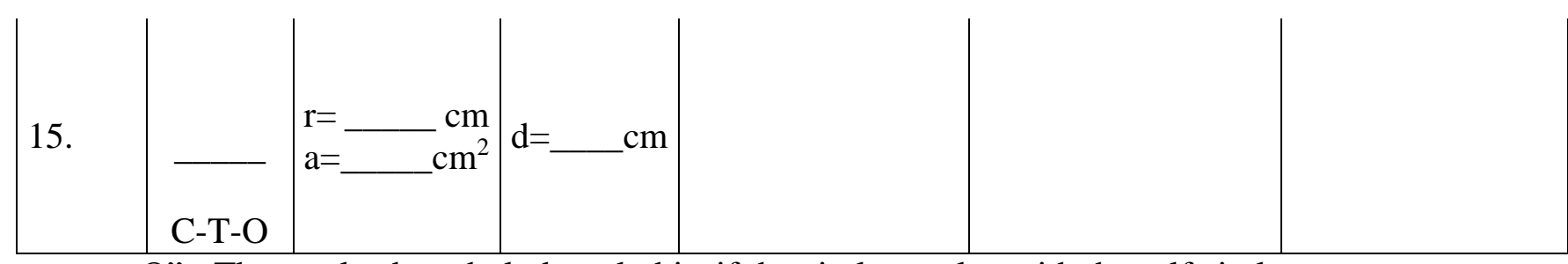

„O" - The test leaders sholud mark this, if the circle overlap with the self circle.

„r" - The radius of the circle.

,a"-The area of the circle.

„d” - The distance between the centers of the self circle and illness circle 
Annex 2: Publications providing the basis of the thesis

I. Sándor Z, Látos M, Pócza-Véger P, Havancsák $\mathrm{R}^{\dagger}$, Csabai M. The drawing version of the pictorial representation of illness and self measure. Psychology and Health. 2020; 17:1-16. IF: 2,528* 


\title{
The drawing version of the pictorial representation of illness and self measure
}

\author{
Zita Sándor, Melinda Látos, Petra Pócza-Véger, Rózsa Havancsák \& Márta \\ Csabai
}

To cite this article: Zita Sándor, Melinda Látos, Petra Pócza-Véger, Rózsa Havancsák \& Márta Csabai (2020): The drawing version of the pictorial representation of illness and self measure, Psychology \& Health, DOI: 10.1080/08870446.2019.1707825

To link to this article: https://doi.org/10.1080/08870446.2019.1707825
(c) 2020 The Author(s). Published by Informa UK Limited, trading as Taylor \& Francis Group

\section{+ View supplementary material $\widetilde{ }$}

曲 Published online: 17 Feb 2020.

Submit your article to this journal

Lll Article views: 522

Q View related articles 두

View Crossmark data ‘ 


\title{
The drawing version of the pictorial representation of illness and self measure
}

\author{
Zita Sándor ${ }^{\mathrm{a}, \mathrm{b}}$, Melinda Látos ${ }^{c}$, Petra Pócza-Véger ${ }^{\mathrm{d}}$, Rózsa Havancsák ${ }^{\mathrm{e}}$ and \\ Márta Csabai ${ }^{\prime}$ (ID \\ ${ }^{\mathrm{a}}$ Faculty of Health and Social Sciences, Gál Ferenc College, Gyula, Hungary; ${ }^{\mathrm{b}}$ Faculty of Medicine \\ Clinical Medicine Doctoral School, University of Szeged, Szeged, Hungary; ${ }^{C}$ Faculty of Medicine, \\ Department of Surgery, University of Szeged, Szeged, Hungary; ${ }^{\text {d}}$ Faculty of Medicine Department of

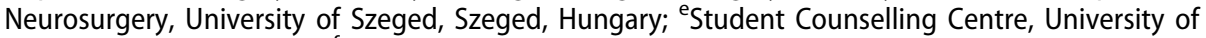 \\ Szeged, Szeged, Hungary; Institute of Psychology, University of Szeged, Szeged, Hungary
}

\begin{abstract}
Objective: We developed and validated a drawing test version of the Pictorial Representation of Illness and Self Measure (PRISM), a visual method to assess the perceived burden of illness and illness perception. Our aim was to test whether the drawing version would allow patients more freedom to deliberately vary both the size and position of circles symbolizing illness and individual coping resources, as well as gain more information about illness representations and available resources. Design and Main Outcome Measures: We applied the PRISM-D test to 500 patients with severe somatic diseases under active hospital treatment. We used Spielberger's State and Trait Anxiety Inventory and Beck's Depression Inventory to assess convergent validity. Results: The PRISM-D test is applicable for inpatients and it can be used to explore their subjective representations. The modifications did not cause any loss in convergent validity as the Self-Illness Separation and the Illness Perception Measure are significantly correlated with levels of depression and anxiety. Conclusion: The drawing test enables more detailed measurement of suffering caused by illness, illness perception and more complex assessment of important factors in a patient's life. The test is adequate for clinical use as well as research among a wide range of somatic inpatients.
\end{abstract}

\section{ARTICLE HISTORY}

Received 21 March 2018

Accepted 12 December 2019

\section{KEYWORDS}

Burden of illness; illness perception; coping; chronic illness; psychological test

\section{Introduction}

Illness is an individual, subjective experience for everyone, and the reactions to illness may also be greatly different. The subjective perception and burden of illness are important factors in recovery because they affect the psychological, social, and

CONTACT Zita Sándor sandorzita89@gmail.com @ Faculty of Health and Social Sciences, Gál Ferenc College, Szent István út 19-19, Gyula 5700, Hungary.

${ }^{\dagger}$ Deceased.

(4) Supplemental data for this article is available online at https://doi.org/10.1080/08870446.2019.1707825.

(C) 2020 The Author(s). Published by Informa UK Limited, trading as Taylor \& Francis Group.

This is an Open Access article distributed under the terms of the Creative Commons Attribution-NonCommercial-NoDerivatives License (http://creativecommons.org/licenses/by-nc-nd/4.0/), which permits non-commercial re-use, distribution, and reproduction in any medium, provided the original work is properly cited, and is not altered, transformed, or built upon in any way. 
somatic outcomes (Petrie, Jago, \& Devcich, 2007). The subjective interpretation of illness is associated with an individual's coping mechanisms and adaptation to stressors, influencing subjective wellbeing and satisfaction with life (Krikorian, Limonero, Vargas, \& Palacio, 2013; Petrie \& Weinman, 2012).

Thus, to encourage positive outcomes, it is important to explore patients' subjective illness perceptions, beliefs and impact of the illness (Cameron \& Leventhal, 2003; Petrie \& Weinman, 2012). The effects of illness on the patient's life need to be explored as well, because the illness is not isolated in a person's life but becomes an organic part of it. Examining how illness affects a person's life and the extent to which illness is embedded in the patient's social environment, physical environment, and life history in a way which is economical and complex at the same time is also important. For example, even though social support is typically viewed as a stable factor in one's life, it can be changed or even eroded by illness (Alferi, Carver, Antoni, Weiss, \& Durán, 2001).

The exploration of resources supporting recovery that are present in one's environment is extremely important-factors such as social support, physical or mental health-protecting habits, and activities that are sources of experiencing joy or success. The presence of these factors indicates a more positive prognosis of the recovery process, and they can serve as resources. A lack of these factors may predict negative outcomes, along with the presence of factors that aggravate recovery, such as relational conflicts, experiences of loss, and strong negative emotions. For this reason, during psychological support for patients with serious medical conditions, there is high priority in the application of methods that enable the exploration of the subjective effects of illness on an individual's personality and life, the factors supporting or aggravating recovery, and the associations between them.

There are many disease-specific and generic methods to study illness impact, perceptions and beliefs (Horne, Weinman, \& Hankins, 1999; Shumaker \& Naughton, 1995; Weinman, Petrie, Moss-Morris, \& Horne, 1996), but for the most part, these measures are too complex and time-consuming for ordinary application in clinical practice. These quantitative methods can be restricted, as patients' beliefs, experiences and feelings are very subjective and often need deeper and more personalized understanding (Cheung, Saini, \& Smith, 2016). These tests are often inappropriate for the exploration of the way illness is embedded in the patient's social environment. Moreover, the validity of these measures greatly depends on the verbal skills of the patients (Büchi \& Sensky, 1999).

Although conventional interview techniques enable the measurement of illness beliefs and suffering and support individual assessment, this method is very timeconsuming and it also assumes that patients have good verbal capacity. This is not the case in many medical situations due to either the type of disease or its method of treatment.

Published data prove that nonverbal methods have better applicability for working with patients with serious medical conditions, as these methods require less energy input from patients and enable a more successful exploration of partially subconscious representations (Broadbent, Ellis, Gamble, \& Petrie, 2006). The conventional drawing tests (e.g. draw their body before or after disease or currently after treatment, draw their illness or the damaged organ) are easy novel methods to assess individual illness 
perceptions and the experiences about their illness and treatment (Tiemensma et al., 2015). According to studies, drawings show associations with clinical and psychological markers of health status in several type of somatic inpatients, e.g. health failure (Reynolds, Broadbent, Ellis, Gamble, \& Petrie, 2007), myocardial infarction (Broadbent, Petrie, Ellis, Ying, \& Gamble, 2004), emergency embolization in postpartum hemorrhage (van Stralen et al., 2010), and vestibular schwannoma (Kaptein et al., 2011). Results show that the drawings could facilitate patients to share their illness experiences, beliefs and feelings, moreover, it had potential benefits for the patients by helping them better understand themselves (Cheung et al., 2016). However, it is hard to assess the role of differences in the drawing ability of the patients in the interpretation. (Tiemensma et al., 2015).

A novel nonverbal test, the PRISM test (Büchi \& Sensky, 1999) is a tool for measuring the subjective suffering caused by illness. The tool uses a visual metaphor that can be applied to measure a patient's perceived somatic burden of suffering due to their illness and the association between the self and the illness. In this nonverbal test, a person puts a red magnetic disk on a white, A4-sized metal board. The white metal board symbolizes the patient's current life situation, while the red disk symbolizes their illness. In the lower right corner of the board, there is a yellow circle that symbolizes the patient's self, and the distance between the self and illness (Self-Illness Separation, SIS) reflects the suffering of the illness burden. A modified version of the test called the PRISM-R1 test enables the examination of illness perception (Reimus, Vingerhoets, Soons, \& Korstanje, 2007). In this version, patients can choose from three different sizes of disks that symbolize their illness, where the size reflects the Illness Perception Measure (IPM).

The PRISM test has been successfully validated, and its reliability has been proven in cases of patients diagnosed with various chronic diseases, such as breast cancer, rheumatoid arthritis, chronic obstructive pulmonary disease, diabetes mellitus, systematic lupus erythematosus, orofacial pain disorder, dermatologic diseases, and longterm cancer survivors (Büchi \& Sensky, 1999; Büchi et al., 2000; 2002; Kassardjian, Gardner-Nix, Dupak, Barbati, \& Lam-McCullock, 2008; Lehmann, Oerlemans, van de Poll-Franse, Vingerhoets, \& Mols, 2011; Mühleisen et al., 2009; Streffer, Büchi, Mörgeli, Galli, \& Ettlin, 2009; Wouters, Reimus, van Nunen, Blokhorst, \& Vingerhoets, 2008). There is a consistently negative correlation between SIS and depression (e.g. Büchi, Sensky, Sharpe, \& Timberlake, 1998; Büchi et al., 2002; Lima-Verde, Pozza, Rodrigues, Velly, \& Guimaraes, 2013), as well as between SIS and experienced pain (e.g. Kassardjian et al., 2008; Streffer et al., 2009) and between SIS and disease-specific and general quality of life (e.g. Meyer, Luethi, Neff, Langer, \& Büchi, 2014; Rumpf, Lontz, \& Uesseler, 2004). The IPM is significantly correlated with health status and wellbeing (Reimus et al., 2007). The PRISM test is also applicable to measuring beliefs and attitudes and can also support therapeutic decision making (Sensky \& Büchi, 2016).

To avoid the need for special tools in the PRISM test (the metal board and the disks), a self-administered version of the test was created (Rumpf et al., 2004). Their findings suggest that the PRISM can be used in a paper-pencil format. However, this version is only applicable to measuring the effects of the illness and its place in the patient's life. In our opinion, however, applying the test using a paper-and-pencil method would offer more options. 
Another modified version of the PRISM test is the PRISM + test, which allows for the representation of other factors besides illness that are also relevant for the patient using various disks. Examples of factors are the patient's family, hobbies, work, and friends (Büchi \& Sensky, 1998, 1999). Therefore, the context of illness, the resources of the patient, and the association of illness, and other factors that are relevant for the patient can be explored. The PRISM + test has been used in several studies, but in most cases the disks symbolized pre-defined factors like pain or fatigue (Gielissen, Prins, Knoop, Verhagen, \& Bleijenberg, 2013; Kassardjian et al., 2008).

\section{The aim of the study}

The aim of the study was to improve the method of the PRISM test by combining the advantages of earlier versions and the drawing tests methods. A new version that was developed for the complex measurement of illness perception and suffering of patients who require active hospital treatment. The new version is called PRISM-D, which is a drawing version of the PRISM + test. The metal disks are replaced with drawing circles, which enables freer visualization of subjective representations compared to earlier tests. Earlier versions of PRISM used a limited number of fixed-size magnetic disks. However, the drawing version allows patients the freedom to vary both the size and the position of the circles more deliberately to symbolize illness and individual coping resources.

This version may also be applicable to exploring the subjective representations of patients under hospital treatment, their current life situations, the important components of their lives, and the associations between them. A further advantage is that it does not measure illness perception in isolation but also explores how it is embedded in the person's life. According to previous studies, drawing can provide richer data collection, elicit patients' beliefs uncensoredly and concentratedly, and reveal patients' previously unknown perceptions and feelings (Cheung et al., 2016; Tiemensma et al., 2015).

Another advantage is that drawings can be preserved, which is essential for followup sessions and useful in therapeutic applications. This helps to observe the changes in both patients' representations and the level of their suffering. Drawing is economical, requires few tools, and the testing process is fast, making it beneficial in clinical applications.

This study examines the applicability of PRISM-D among a wide, non-disease-specific population of somatic patients under active hospital treatment. We also examine whether the test can provide additional information compared to earlier versions; whether the patients take advantage of the freedom of visualization offered by the drawing test; and whether the method is applicable for the measurement of patients' current life situation, important components of their lives, the subjective importance of the illness, the extent to which it is embedded in their lives, and the associations between these factors. Additionally, we examine whether the advantages of the earlier PRISM tests are preserved in the complex drawing test version and whether the results fit with earlier results. 


\section{Methods}

\section{Patient sample and procedure}

The PRISM-D test and its post-test protocol were applied to a sample of 500 patients diagnosed with somatic disease under active hospital treatment. The applicability of the test in clinical practice was examined among a broad spectrum of somatic patients. Inculsion criteria were: being older than 18 years old; being diagnosed with one of these illnesses: cancer, gastro-intestinal disease, chronic renal insufficiency, lumbar degenerative disc disease; being under active hospital treatment; being able to participate in a test (due to their illness condition); and a voluntary agreement to participate. The sample was randomly selected from the patients who met all the criteria (convenience sampling method).

The data collection was conducted in three steps: Firstly, in a pilot study, the PRISM-D test was tried on a random sample of 25 hospital in-patients to find out whether the subjects could interpret the instructions and tasks of the test (measured by structured interview). After we had found that all sample members (who belonged to various illness groups) were able to understand the instructions, we used the PRISM-D test with a larger sample (as a target, 300 persons) in the second step of our research. Patients were randomly selected for the sample from the following illness groups: cancer, gastro-intestinal disease, chronic renal insufficiency, and lumbar degenerative disc disease. There were 278 patients in total who met all the criteria during the research period.

In the third step of data collection, to examine the convergent validity, the PRISM-D test, Spielberger's State and Trait Anxiety Inventory (STAl), and Beck's Depression Inventory (BDI) were used on a sample of 197 other patients. The subjects were grouped in three disease groups: cancer, gastro-intestinal diseases, and chronic renal failure.

Testing was conducted in the hospital departments of university clinical practice venues and national clinical centers. Our permission of research specified the targeted sample sizes in each period of data collection, the size of the final sample (500 persons), the targeted population and the measurement tools used.

Before the specific PRISM-D instructions were given, we obtained informed consent from the participants and recorded their demographic (age, sex) and illness specific data (illness type). Each test recording lasted approximately 10-15 minutes and was followed by a post-test to let the participants define the meanings of the circles (5 min). After completing the PRISM-D test, patients completed the questionnaires (STAl, BDI) on their own.

\section{Measures}

\section{PRISM-D test}

In the PRISM-D drawing test, participants are given a pre-printed A4-size sheet of paper with a yellow circle that is $7 \mathrm{~cm}$ in diameter in the lower right corner. The circle symbolizes the patient's self, exactly as in the original PRISM test (Büchi \& Sensky, 
1999) (Supplementary material, Figure 1). The test leaders give standard instructions to the participants and note the answers (Supplementary material, Figure 2).

Firstly, the participants are asked to draw their illness with a red felt marker in a location where they would place it in their current life situation. SIS can be defined as the distance measured between the circles drawn on the test sheet. The distance must be measured between the centers of the two circles according to the original test (Büchi \& Sensky, 1999). The size of the visualized illness can also be measured and is interpreted as the IPM according to the PRISM-R1 version (Reimus et al., 2007). However, because the PRISM-D test is a drawing test, the size of the drawn circles can vary. We calculated the area of the drawn circles by measuring their radius, thus getting the values of IPM.

In the second part of the test, participants can draw other circles that symbolize actual important factors in their lives with felt markers of various colors (yellow, orange, pink, purple, blue, green, brown, and black). Participants were not given any instructions or suggestions for what factors they should draw. They could freely decide on this so that only their chosen factors were represented in the test. There are no limitations to how many factors can be drawn.

In the post-test, the patients gave the meanings associated to the circles. The researchers kept verbatim record of the meanings patients attributed to the circles and the order in which they were drawn. Responses were categorized by their meanings.

As in the case of PRISM + tests (Büchi \& Sensky, 1998, 1999), the distance of factors drawn can also be measured (the self-family, self-work, and self-hobby distances), although these factors are only present on the drawing test if the patients consider them relevant. Besides the distances, the sizes of the factors can be examined as well (by calculating their area).

\section{STAI}

The anxiety level of the patients was measured by the Spielberger STAI (Spielberger, Gorsuch, \& Lushene, 1970). The Trait Anxiety Scale (STAI-T) assesses the general state (how one feels in general), and the State Anxiety Scale (STAI-S) measures the patients' anxiety level about an event (how one feels right now at this very moment). Each scale includes 20 items, and the answers range from 1 (not at all) to 4 (very much so). The total scores range from 20 to 80 . The reliability of the scale (Cronbach alpha) was 0.77 in this sample.

\section{$B D I$}

The severity of depression was measured by the 21-question BDI (Beck, Ward, Mendelson, Mock, \& Erbaugh, 1961; Richter, Werner, Heerlein, Kraus, \& Sauer, 1998). The questions of this tool list four statements that describe feelings in the past days and weeks. The scores range from 0 to 3 . The lowest total score is 0 , and the highest is 84 . The internal consistency of the scale was sufficient for our sample.

\section{Data analysis}

In the pilot study, we carried out the qualitative analysis of the structured interviews regarding the applicability of the test. Analysis of the circles (other than the one 
symbolizing the illness) drawn on the PRISM-D test started with the categorization of responses by their meanings. The encoding of responses was done by two independent encoders (in cases where they differed, a third encoder was included).

The statistical analysis was performed with SPSS Version 21. The parameters measured were the distance between the self and the factors drawn on the PRISM-D test (in centimeters), as well as the area of these factors (in square centimeters). Descriptive statistics were calculated from the data, such as percentages, means, standard deviations, and medians.

In the case of the BDI and STAI tests, the mean values of total scores and their standard deviations were calculated.

Gender differences in illness-circle characteristics represented on the PRISM test were analyzed with Student's t-test. Associations with age were analyzed with Pearson's correlation.

The convergent validity of the PRISM-D test was examined by Pearson's correlation coefficients between SIS and BDI, STAI-S, STAI-T scales, as well as between the IPM and the BDI, STAI-S, and STAI-T scales. In addition, comparative analysis was conducted using a student's t-test and chi-squared test between the total scores of the BDI, STAI-S, and STAI-T scales and the factors drawn on the PRISM-D test. For each statistical procedure, the assumptions were tested and they were met in case of the results presented in the paper.

\section{Results}

\section{Participants' characteristics}

The participants comprised $44.4 \%$ men $(\mathrm{N}=222)$ and $55.6 \%$ women $(\mathrm{N}=278)$. Their mean age was 51.9 years $(S D=16.06$ ) with a range of 14 to 86 years. The distributions of the sample by disease were $36 \%$ cancer, $31 \%$ lumbar degenerative disc disease or other locomotor problems, $19 \%$ chronic renal failure, $7 \%$ gastrointestinal diseases, and $7 \%$ hospital in-patients with other diseases. There were no gender differences in either the SIS or the IPM (Student's t-test, $\mathrm{p}>0.05$ ). There were no significant correlations between either the SIS score and age or the IPM score and age (Pearson's correlation coefficients, $\mathrm{p}>0.05$ ).

\section{PRISM-D task's characteristics}

In the pilot stage of the study, the PRISM-D test and structured interviews were used with 25 hospital in-patients to test the applicability of the new method. Results suggested that all patients could comprehend and execute the tasks.

\section{IIIness}

The SIS showed heterogeneous results. The mean distance was $11.19 \mathrm{~cm}$, which implies considerable suffering from the illness burden, as a smaller distance from the self on the PRISM test indicates a higher level of suffering (Büchi \& Sensky, 1999; Büchi et al., 1998). The standard deviation is high $(7.53 \mathrm{~cm})$, which implies large individual variation. The measured minimum value was $0 \mathrm{~cm}$ (self in the illness, 
overlapping circle centers), and the maximum value was $29.9 \mathrm{~cm}$ (Supplementary material, Figures 3 and 4).

Furthermore, $16.06 \%$ of the participants represented the illness either within the self (Supplementary material, Figure 5) or completely overlapping with the self (if the circle of the illness was bigger than the circle of the self), which implies a large illness burden. In $4.34 \%$ of the sample, the illness was represented as partially overlapping with the self (Supplementary material, Figure 6). In $79.60 \%$ of the sample, the circles were separated. In $4.19 \%$ of the cases where the illness was separated from the self, the two circles were touching.

The sizes of the circles drawn were very diverse. Importantly, the circles were drawn by freehand and did not have a regular shape in many cases. Thus, the mean value of the diameters was used to calculate the area values. The mean area of the drawn illness circles was $23.09 \mathrm{~cm}^{2}$, which is smaller than the area of the preformed self-circle. The standard deviation of the area of illness was $43.64 \mathrm{~cm}^{2}$, which implies high heterogeneity in the answers. The area of the smallest circle was $0.1 \mathrm{~cm}^{2}$, which is practically a tiny point. The area of the largest circle was $415.27 \mathrm{~cm}^{2}$, which nearly occupied the entire sheet of paper. Furthermore, $78.4 \%$ of all drawn circles had an area smaller than the self; $10.3 \%$ had a similar size to the self; and $11.3 \%$ were larger than the self. Finally, $92.05 \%$ of the drawn circles were not filled with color, and $7.95 \%$ were colored.

\section{Other drawn circles}

After they drew the illness circle, in the second part of the test, patients could freely draw the important things in their lives. The participants drew various numbers of circles with various meanings. On average, they drew 4.81 circles besides the illness circle. The standard deviation was relatively high (2.86), which implies high diversity in the number of circles drawn. Only $1 \%$ of the participants were unable to draw any factors other than their illness. The highest number of circles drawn in a test setting was 23. The number of factors drawn can imply either the complexity or emptiness of life. However, it could also mean a narrowed focus on the illness, its treatment, and the current life situation.

The participants could freely associate an interpretation to the circles, and the test leader recorded their meanings according to the explanations that the patients gave word for word. During the analysis, these contents were categorized by meaning categories.

We set up separate categories for 'family members' (family, partner, relatives) and 'friends' (friends, colleagues, acquaintances, neighbors). These sub-categories were further categorized under the main category of 'social support'. There were separate categories for 'work' (job and work activities) and for 'hobbies' (any recreational activity was classified as a hobby). In addition, there were categories for 'health' (health and related meanings), 'recovery' (healing, recovery and related meanings), and 'treatement-related factors' (meanings related to the treatment of illness and hospital environment). Using the latter three categories, we created a new category called 'illness-related factors'. There was another category for 'negative stressors', which 
comprised factors affecting the person unpleasantly or negatively, such as negative emotions, experiences of loss, and relationship conflicts.

Some of the circles on the test $(26.93 \%)$ could not be categorized due to their uniqueness and low occurrence. The following responses occurred frequently (less than $5 \%$ prevalence each): financial security, home, nature, religion/God, deceased loved ones, former spouses, a variety of feelings, love, and freedom. Detecting these factors can make an important contribution to individual case management and effective intervention work. The uniqueness of the tests and the subjective meanings of the circles are demonstrated in Figures 7 and 8 (Supplementary material).

After analyzing the distribution of meaning categories presented above, it can be concluded that 'family' was the most frequent factor, which was drawn by $92.3 \%$ of participants. However, only $24.1 \%$ drew 'friends'. On the whole, $6.6 \%$ did not draw any social support, while $65.7 \%$ of participants drew more than one circle to represent significant others.

Only $27.9 \%$ of the participants drew the 'work', and $22.5 \%$ drew 'hobbies'. A significant proportion of participants drew circles with meanings related to their health condition: 'health' (15\%), 'recovery' (9.1\%), and 'treatement-related factors' (7.5\%). An additional $5.9 \%$ of participants represented 'negative stressors' in their life (relational conflicts, experiences of loss, financial problems, earlier illnesses, fears, and thoughts on passing). This suggests the presence of factors that are potentially aggravating recovery, which need to be explored and treated if necessary, which is an important task of psychological support (Supplementary material, Table 1).

\section{Validity}

\section{Self-IIlness separation (SIS)}

SIS had a significant negative correlation with the total score on the BDI (Pearson's correlation coefficients, $r=-0.317, p<0.001$ ), which means that the greater depression a participant had experienced, the closer they drew their illness to the self. The participants' STAI-S scores had a significant negative correlation with SIS $(\mathrm{R}=-0.309$, $\mathrm{p}<0.001)$. These results imply that test participants with a higher state anxiety level represented their illness as being closer to the self. There was also a significant but weak correlation between the SIS and STAI-T score $(R=-0.195, p=0.028)$, which implies that people with a higher trait anxiety level represented their illness as being closer to the self (Supplementary material, Table 2).

\section{Illness perception measure}

The area measured in square centimeters of the represented illness and the participants' total BDI scores had a weak but significant positive correlation (Pearson's correlation coefficients, $R=0.183, p=0.36$ ). This result suggests that test subjects experiencing higher levels of depression drew a larger circle to represent their illness. The size of the circle symbolizing illness had a weak but significant correlation with STAI-T $(R=0.214, p=0.013)$, which implies that people experiencing higher levels of enduring anxiety drew a larger circle for their illness (Supplementary material, Table 2). 


\section{Associations between illness circle position and anxiety and depression level}

\section{Illness circle inside vs. outside the self}

According to the results, SIS was associated with clinical variables, and there was also a significant association between patients' mood and their representation of their illness either within the self or separated from it. Patients representing their illness within or overlapping with the self (in cases of circles larger than the self) scored significantly higher on the depression (BDI) scale than those who represented their illness as being separated from the self (student's t-test, $p=0.004$, $d f=131$ ).

The STAI-S score had a marginally significant association with illness position (illness circle inside vs. outside of the Self) $(p=0.059, d f=185)$. People who drew their illness within or overlapping with the self had higher STAI-S scores than those who drew their illness as separated from the self. Trait anxiety had no significant effect on the position of the illness circle (Student's t-test, p>0.05) (Supplementary material, Table 3).

\section{Associations between other circle characteristics with anxiety and depression level}

\section{Representation of family}

People not representing the 'family' category (e.g. whole family, family members, partner) on the PRISM-D test had a significantly higher state anxiety value than those who represented at least one family member (student's t-test, $p=0.028, \mathrm{df}=170$ ). Participants who did not represent any family member scored an average of 53.14 points on the STAI-S scale $(S D=15.11)$. Those who represented at least one family member scored only 41.57 on average $(S D=13.41)$. The number, size, and distance of family-category circles were not associated with the scales of depression or anxiety.

\section{IIIness-related factors}

People who represented 'illness-related factors' had significantly lower state anxiety levels $(M=36.82, S D=11.15)$ compared to those who did not represent such factors $(\mathrm{M}=43.60, \mathrm{SD}=13.93)$ (Student's t-test, $\mathrm{p}=0.004$, $\mathrm{df}=168)$. The factors most frequently represented were health, recovery, surgery or other treatment and expected improvement, attitude and quality of service provided by physicians and health care personnel, and general hospital experience.

\section{Representations of negative stressors}

People who drew any circle with a negative meaning (e.g. relational conflicts, experiences of loss, financial problems, earlier illnesses, fears, and thoughts on passing) had a higher rate of depression measured by BDI (chi-squared test, $p=0.032$, df $=1$ ). Furthermore, $75 \%$ of people who represented 'negative stressors' had high BDI scores, as opposed to $36.7 \%$ for those who did not represent any negative factors.

There were not any significant associations between anxiety or level of depression and the other circles drawn on the test (work, hobby, health, recovery $-p>0,05$ in all cases). 


\section{Discussion}

Our results suggest that the PRISM-D test is widely applicable among patients under active hospital treatment. The upgraded drawing version of the test can adequately integrate the advantages of earlier versions and conventional drawing tests. The elimination of the metal disks and thus the application of the test as a drawing test not only reduce the number of tools necessary but also enable easier and more economical application in clinical practice, giving the patients the opportunity of free visualization. Rumpf et al. (2004) previously called attention to the advantages of drawing in the self-administered version of the PRISM test. However, the advantages of free visualization are especially notable when participants can represent other factors present in their life beyond their illness.

The PRISM-D test enables patients to represent factors in their lives without restricting them to a fixed order, size, or relative placement. The PRISM-D test operates without predefined categories of meaning. Participants may freely connect meanings to the circles drawn, allowing the exploration of subjective representations. In this way, the test can be adapted to measure patients' visualizations of their illness, as well as explore the extent to which their illness affects their lives. Furthermore, it allows the exploration of factors that could potentially assist recovery, aspects of support that are relevant to individual patients, and even factors that are aggravating recovery and other difficulties in the individual's life. This process helps to understand the subjective importance of these factors and the connections between them.

After finishing the test (similarly to earlier PRISM + tests), patients can make a visual summary, which in itself may have therapeutic effects. In addition, during the course of clinical work, the test could help to collect more accurate information for the screening of problem behaviors or the design of therapy, and it may even be applied as a therapeutic tool on its own. In contrast to the metal board version, drawing tests are retainable, which is an important advantage. Participants may even take their tests with them, or the test leaders could keep them at hand during therapy. The retained tests could be used for follow-ups and the detection of any changes in illness perception, as well as changes or in the subjective importance and connections of factors in the lives of patients.

Another great advantage of the PRISM-D test is that it is a suitable tool for exploring individual representations, which could make it applicable for clinical use in the course of therapy. At the same time, it allows for quantitative analysis that could be used for screening, quantitative follow-up of changes, and research. The convergent validity of the PRISM-D test was not lost during its development since the SIS is significantly correlated with the total score on the BDI. This result is consistent with the earlier studies conducted with the original PRISM test (Büchi et al., 1998; Gielissen et al., 2013; Rumpf et al., 2004). In addition, a significant correlation was measured between the SIS and the scales of the STAI, which is consistent with earlier studies using the original PRISM test that found significant connection between anxiety or perceived stress and the SIS (Klis, Vingerhoets, de Wit, Zandbelt, \& Snoek, 2008; Krikorian et al., 2013).

Our results suggest that patients who drew an illness circle close to the self showed higher level of depression and anxiety. According to previous studies (Büchi \& Sensky, 
1999) the distance between the self and the illness indicates the patient's perceived illness burden and suffering. By analyzing the position of the illness circle, we could distinguish two main categories: (1) the illness circle is inside the self circle, or overlapping with the self (in cases where the illness circle is larger than the self circle), (2) illness is outside, separated from the self circle. Our results suggest that the two types of illness position are significantly associated with different levels of depression and state anxiety. Similar findings were detected by Peter et al. (2016) as well. This association implies that patients who felt that the illness is 'inside' of their self, had more negative mood than patients who perceived a distance from the illness.

PRISM-D enables a more differentiated measurement of illness perception as well. Our results show that the participants take advantage of this and draw widely different sizes of circles for illness, from as small as one millimeter in diameter to a large red circle nearly covering the whole sheet of paper. According to our results, the IPM had a significant negative correlation with the BDI and the total STAI-T score. These findings suggest that a bigger size of drawn illness is associated with a more depressive mood and higher anxiety level.

These findings are associated with previous studies results of PRISM-R1 (Reimus et al., 2007), where participants could choose from only three sizes of circles. They found that the size of the illness circle (IPM) was negatively associated with health status, life satisfaction and psychological well-being of psoriasis patients. Another previous study (Klis et al., 2008) found significant negative correlation between well-being index (WHO-5) and IPM (a version where the illness circle can have three different sizes). The association between the size of the illness and a worse illness perception has been revealed by conventional drawing tests as well (Broadbent, Schoones, Tiemensma, \& Kaptein, 2018).

The results suggest that it is practical to allow participants the freedom of visualization regarding the size of illness representation. The results of our quantitative analysis of other circles drawn on the test emphasize the importance of examining these factors, as connections were found between patients' mood and the visualized social support, illness-related factors, and visualized negative factors. The representation of the family on the test was correlated with a lower level of anxiety. Patients who did not represent family among the actual important aspects in their live perhaps could have done so because of either a perceived or actual lack of family, or perhaps a narrowed focus on illness. Such patients experienced a higher level of anxiety than the patients who represented at least one family member in the test.

The results showed that $31.6 \%$ of the patients represented factors related to health, illness, and recovery. People who represented their current treatment and its expected effects or health care personnel as important sources of short-term recovery ('illnessrelated factors') experienced lower levels of anxiety than those who did not represent such factors. There was no such connection between anxiety and the 'health' or 'recovery' categories. A possible explanation is that the 'illness-related factors' category consists of specific recovery-related factors, while the 'health' and the 'recovery' categories may instead symbolize patients' wishes with regard to their actual health status. The importance of this result lies in its usability in clinical practice. 
The representation of the 'negative stressors' category on the test was associated with the level of depression. While this result is not surprising, it is important because it further shows the usability of the PRISM-D test. It can be concluded that the representations of negative factors in one's life on the PRISM-D test may be interpreted as potential complication factors or obstacles that make recovery more difficult, and they also imply the increased presence of depressive symptoms. The PRISM-D test could contribute to the quick and easy exploration of these negative factors and to the screening of patients who have factors in their life that may aggravate physical and psychological recovery. Nevertheless, the qualitative aspects of the individual meaning of contents need to be analyzed by further studies.

The study has a number of limitations that should be mentioned. Firstly, the convenience sampling methodology raises questions regarding the representativeness of our results. Moreover, our sample consisted of a heterogeneous patient population. The study was based on only one measurement. No test-retest reliability assessment has been conducted.

\section{Conclusion}

Our results show that the PRISM-D test keeps or improves upon the virtues of the earlier PRISM tests. Furthermore, it is a more economical method that provides more complex information. By combining the advantages of earlier versions, the proposed tool could be applied for measuring the suffering caused by illness, illness perception, the extent to which illness is embedded in one's life, and the connections between these factors. It is a simple, quick, and economical yet complex tool. Given its ability to provide both quantitative and qualitative data, the tool is adequate for clinical use as well as research among a wide range of somatic patients under hospital treatment.

\section{Acknowledgements}

We would like to thank the clinical centers where the data collection was conducted for their support. We also thank $\mathrm{Dr}$ Peter Kovács clinical psychologist for his help with the data collection.

\section{Disclosure statement}

No potential conflict of interest was reported by the authors.

\section{ORCID}

Márta Csabai (iD) http://orcid.org/0000-0002-3194-6208

\section{References}

Alferi, S. M., Carver, C. S., Antoni, M. H., Weiss, S., \& Durán, R. E. (2001). An exploratory study of social support, distress, and life disruption among low-income Hispanic women under treatment for early stage breast cancer. Health Psychology, 20(1), 41-46. doi:10.1037/0278-6133.20. 
Beck, A. T., Ward, C. H., Mendelson, M., Mock, J., \& Erbaugh, J. (1961). An inventory for measuring depression. Archives of General Psychiatry, 4(6), 561-571. doi:10.1001/archpsyc.1961. 01710120031004

Broadbent, E., Ellis, C. J., Gamble, G., \& Petrie, K. J. (2006). Changes in patient drawings of the heart identify slow recovery after myocardial infarction. Psychosomatic Medicine, 68(6), 910-913. doi:10.1097/01.psy.0000242121.02571.10

Broadbent, E., Petrie, K. J., Ellis, C. J., Ying, J., \& Gamble, G. (2004). A picture of health - myocardial infarction patients' drawings of their hearts and subsequent disability: A longitudinal study. Journal of Psychosomatic Research, 57(6), 583-587. doi:10.1016/j.jpsychores.2004.03.014

Broadbent, E., Schoones, J. W., Tiemensma, J., \& Kaptein, A. A. (2018). A systematic review of patients' drawing of illness: Implications for research using the Common Sense Model. Health Psychology Review, 17, 1-139. doi:10.1080/17437199.2018.1558088

Büchi, S., Buddeberg, C., Klaghofer, R., Russi, E. W., Brändli, O., Schlösser, C., ... Sensky, T. (2002). Preliminary validation of PRISM (Pictorial Representation of Illness and Self Measure)-A brief method to assess suffering. Psychotherapy and Psychosomatics, 71(6), 333-341. doi:10.1159/ 000065994

Büchi, S., \& Sensky, T. (1998). PRISM (Pictorial Representation of Illness and Self Measure)-A simple visualisation method for research and practice. Verhaltenstherapie, 8(2), 112-117. doi: $10.1159 / 000030636$

Büchi, S., \& Sensky, T. (1999). PRISM: Pictorial Representation of Illness and Self Measure. A brief nonverbal measure of illness impact and therapeutic aid in psychosomatic medicine. Psychosomatics, 40(4), 314-320. doi:10.1016/S0033-3182(99)71225-9

Büchi, S., Sensky, T., Sharpe, L., \& Timberlake, N. (1998). Graphic representation of illness: A novel method of measuring patients' perceptions of the impact of illness. Psychotherapy and Psychosomatics, 67(4-5), 222-225. doi:10.1159/000012284

Büchi, S., Villiger, P., Kauer, Y., Klaghofer, R., Sensky, T., \& Stoll, T. (2000). PRISM (Pictorial Representation of Illness and Self Measure): A novel visual method to assess the global burden of illness in patients with systemic lupus erythematosus. Lupus, 9(5), 368-373. doi:10. $1191 / 096120300678828479$

Cameron, L. D., \& Leventhal, H. (2003). The self-regulation of health and illness behavior. London: Routledge.

Cheung, M. M. Y., Saini, B., \& Smith, L. (2016). Using drawings to explore patients' perceptions of their illness: A scoping review. Journal of Multidisciplinary Healthcare, 9, 631-646. doi:10.2147/ JMDH.S120300

Gielissen, M. F., Prins, J. B., Knoop, H., Verhagen, S., \& Bleijenberg, G. (2013). Pictorial Representation of Self and Illness Measure (PRISM): A graphic instrument to assess suffering in fatigued cancer survivors. Psychological Assessment, 25(2), 658-663. doi:10.1037/a0031526

Horne, R., Weinman, J., \& Hankins, M. (1999). The beliefs about medicines questionnaire: The development and evaluation of a new method for assessing the cognitive representation of medication. Psychology \& Health, 14(1), 1-24. doi:10.1080/08870449908407311

Kaptein, A. A., Zandstra, T., Scharloo, M., Vogel, J. J., Broadbent, E., Hughes, B. M., ... van der Mey, A. G. L. (2011). "A time bomb ticking in my head": Drawings of inner ears by patients with vestibular schwannoma. Clinical Otolaryngology, 36(2), 183-184. doi:10.1111/j.1749-4486. 2011.02264.x

Kassardjian, C. D., Gardner-Nix, J., Dupak, K., Barbati, J., \& Lam-McCullock, J. (2008). Validating PRISM (Pictorial Representation of Illness and Self Measure) as a measure of suffering in chronic non-cancer pain patients. The Journal of Pain, 9(12), 1135-1143. doi:10.1016/j.jpain. 2008.06.016

Klis, S., Vingerhoets, A. J., de Wit, M., Zandbelt, N., \& Snoek, F. J. (2008). Pictorial Representation of Illness and Self Measure Revised II (PRISM-RII): A novel method to assess perceived burden of illness in diabetes patients. Health and Quality of Life Outcomes, 6(1), 104. doi:10.1186/ 1477-7525-6-104

Krikorian, A., Limonero, J. T., Vargas, J. J., \& Palacio, C. (2013). Assessing suffering in advanced cancer patients using Pictorial Representation of Illness and Self-Measure (PRISM), preliminary 
validation of the Spanish version in a Latin American population. Supportive Care in Cancer, 21(12), 3327-3336. doi:10.1007/s00520-013-1913-5

Lehmann, V., Oerlemans, S., van de Poll-Franse, L. V., Vingerhoets, A. J., \& Mols, F. (2011). Suffering in long-term cancer survivors: An evaluation of the PRISM-R2 in a population-based cohort. Quality of Life Research, 20(10), 1645-1654. doi:10.1007/s11136-011-9911-x

Lima-Verde, A. C., Pozza, D. H., Rodrigues, L. L., Velly, A. M., \& Guimaraes, A. S. (2013). Cross-cultural adaptation and validation for Portuguese (Brazilian) of the Pictorial Representation of Illness and Self Measure instrument in orofacial pain patients. Journal of Orofacial Pain, 27(3), 271-275. doi:10.11607/jop.1070

Meyer, M., Luethi, M. S., Neff, P., Langer, N., \& Büchi, S. (2014). Disentangling tinnitus distress and tinnitus presence by means of EEG power analysis. Neural Plasticity, 2014, 1-13. doi:10. $1155 / 2014 / 468546$

Mühleisen, B., Büchi, S., Schmidhauser, S., Jenewein, J., French, L. E., \& Hofbauer, G. L. (2009). Pictorial Representation of Illness and Self Measure (PRISM): A novel visual instrument to measure quality of life in dermatological inpatients. Archives of Dermatology, 145(7), 774-780. doi:10.1001/archdermatol.2009.121

Peter, N., Kleinjung, T., Horat, L., Schmidt-Weitmann, S., Meyer, M., Büchi, S., \& Weidt, S. (2016). Validation of PRISM (Pictorial Representation of Illness and Self Measure) as a novel visual assessment tool for the burden of suffering in tinnitus patients. Health and Quality of Life Outcomes, 14(1), 1-9. doi:10.1186/s12955-016-0454-2

Petrie, K. J., Jago, L. A., \& Devcich, D. A. (2007). A role of illness perceptions in patients with medical conditions. Current Opinion in Psychiatry, 20, 163-167. doi:10.1097/YCO. 0b013e328014a871

Petrie, K. J., \& Weinman, J. (2012). Patients' perceptions of their illness: The dynamo of volition in health care. Current Directions in Psychological Science, 20(10), 1-6. doi:10.1177/ 0963721411429456

Reimus, J. L., Vingerhoets, A. J., Soons, P. H., \& Korstanje, M. J. (2007). Suffering in psoriasis patients: Its relation with illness severity and subjective well-being. International Journal of Dermatology, 46(10), 1042-1045. doi:10.1111/j.1365-4632.2007.03191.x

Reynolds, L., Broadbent, E., Ellis, C. J., Gamble, G., \& Petrie, K. J. (2007). Patients' drawings illustrate psychological and functional status in heart failure. Journal of Psychosomatic Research, 63(5), 525-532. doi:10.1016/j.jpsychores.2007.03.007

Richter, P., Werner, J., Heerlein, A., Kraus, A., \& Sauer, H. (1998). On the validity of the Beck Depression Inventory. A review. Psychopathology, 31(3), 160-168. doi:10.1159/000066239

Rumpf, H. J., Lontz, W., \& Uesseler, S. (2004). A self-administered version of a brief measure of suffering: First aspects of validity. Psychotherapy and Psychosomatics, 73(1), 53-56. doi:10. $1159 / 000074440$

Sensky, T., \& Büchi, S. (2016). PRISM, A novel visual metaphor to measure personally salient appraisals, attitudes and decision-making: Qualitative evidence synthesis. PLos One, 11(5), e0156284. doi:10.1371/journal.pone.0156284

Shumaker, S. A., \& Naughton, M. J. (1995). The international assessment of health-related quality of life: A theoretical perspective. In S. A. Shumaker \& R. Berzon (Eds.), The international assessment of health-related quality of life: Theory, translation, measurement and analysis (pp. 3-10). Oxford: Rapid Communications.

Spielberger, C. D., Gorsuch, R. L., \& Lushene, R. E. (1970). Manual for the state-trait anxiety inventory. Palo Alto, CA: Consulting Psychologists Press.

Streffer, M. L., Büchi, S., Mörgeli, H., Galli, U., \& Ettlin, D. (2009). PRISM (Pictorial Representation of Illness and Self Measure): A novel visual instrument to assess pain and suffering in orofacial pain patients. Journal of Orofacial Pain, 23(2), 140-146. doi: 10.5167/uzh-25322.

Tiemensma, J., Pereira, A. M., Romijn, J. A., Broadbent, E., Biermasz, N. R., \& Kaptein, A. A. (2015). Persistent negative illness perceptions despite long-term biochemical control of acromegaly: Novel application of the drawing test. European Journal of Endocrinology, 172(5), 583-593. doi: 10.1530/EJE-14-0996 
van Stralen, G., van Stralen-Ruijten, L. L., Spaargaren, C. F., Broadbent, E., Kaptein, A. A., \& Scherjon, S. A. (2010). Good quality of life after emergency embolisation in postpartum haemorrhage. Journal of Psychosomatic Obstetrics \& Gynecology, 31(4), 285-288. doi:10.3109/ $0167482 X .2010 .528092$

Weinman, J., Petrie, K. J., Moss-Morris, R., \& Horne, R. (1996). The illness perception questionnaire: A new method for assessing the cognitive representation of illness. Psychology \& Health, 11(3), 431-445. doi:10.1080/08870449608400270

Wouters, E. J., Reimus, J. L., van Nunen, A. M., Blokhorst, M. G., \& Vingerhoets, A. J. (2008). Suffering quantified? Feasibility and psychometric characteristics of 2 revised versions of the Pictorial Representation of Illness and Self Measure (PRISM). Behavioral Medicine, 34(2), 65-78. doi:10.3200/BMED.34.2.65-78 
Annex 2: Publications providing the basis of the thesis

II. Sándor Z, Csabai M. A PRISM-D rajzteszt alkalmazása a daganatos betegséggel összefüggő érzelmi és kognitív reprezentációk komplex vizsgálatára. Orvosi Hetilap. 2018;59(48): 2021-2030. IF: 0,53 


\title{
A PRISM-D rajzteszt alkalmazása a daganatos betegséggel összefüggő érzelmi és kognitív reprezentációk komplex vizsgálatára
}

\author{
Sándor Zita ${ }^{1,2}$. Csabai Márta dr. ${ }^{3}$ \\ 'Szegedi Tudományegyetem, Általános Orvostudományi Kar, Klinikai Orvostudományok Doktori Iskola, Szeged \\ ${ }^{2}$ Gál Ferenc Főiskola, Egészség és Szociális Tudományi Kar, Gyula \\ ${ }^{3}$ Szegedi Tudományegyetem, Bölcsészettudományi Kar, Pszichológiai Intézet, Szeged
}

\begin{abstract}
Bevezetés: Egy súlyos betegség lelki megélésének, egyéni értelmezésének a vizsgálata fontos feladat, ugyanis ezen tényezők befolyásolhatják a megküzdéses válaszokat, illetve a betegség pszichés és szomatikus kimenetelét. A klinikai gyakorlatban a maladaptív reakciók szúrése, illetve a pszichés intervenciók hatékony megtervezése érdekében olyan, széles körben alkalmazható mérőeszközre van szükség, mely a betegséggel összefüggő érzelmi és kognitív reprezentációkat gyorsan, mégis kellően részletesen méri.

Célkitüzés: Tanulmányunk célja a Pictorial Representations of Illness and Self Measure teszt általunk kifejlesztett rajztesztverziója (PRISM-D) és utótesztje alkalmazhatóságának vizsgálata volt a klinikai gyakorlatban, daganatos betegek körében.

Módszer: Vizsgálatunk során 150 fó, kezelés alatt álló daganatos beteggel vettük fel a Pictorial Representations of Illness and Self Measure rajztesztverzióját és annak utótesztjét.

Eredmények: A teszten nyerhető kvantitatív adatok alapján a vizsgált személyek nagymértékú, betegségtől való lelki szenvedést éltek meg, bár e tekintetben a mintára nagyfokú heterogenitás jellemző. A betegek többsége negatív érzéseket társított a betegségéhez, úgymint distressz, félelem, szomorúság, bizonytalanságérzés. A betegségreprezentációk tekintetében megjelent a betegség jelzésként, akadályként, megoldandó feladatként, küzdelemként, veszteségként, csapásként és személyes kudarcként való interpretálása. A betegséget szimbolizáló kör mérete és térbeli elhelyezkedése alapján azonosíthatók a betegséget tagadó, illetve bagatellizáló betegek, továbbá a betegséget rendkívül súlyosnak megélő személyek is. Ezen információk feltárása a betegséggel való megküzdés és a betegségviselkedés szempontjából kiemelten fontos.

Következtetések: Vizsgálatunk alapján a teszt mind a klinikai gyakorlatban, mind a kutatásokban jól alkalmazható, gyors és komplex információt nyújtó mérőeszköz, mely alkalmas a betegséggel összefüggő érzelmi és kognitív reprezentációk kvantitatív és kvalitatív mérésére kórházi környezetben, súlyos, akár verbálisan nehezen hozzáférhető betegek esetében is.
\end{abstract}

Orv Hetil. 2018; 159(48): 2021-2030.

Kulcsszavak: betegségpercepció, megküzdés, pszichológiai teszt, rajzolás, daganatos betegek

\section{Application of the PRISM-D drawing test to the complex examination of cancer-related emotional and cognitive representations}

Introduction: Studying the psychological experience and the individual interpretation of a serious illness is an important task, as these factors can affect coping strategies and the psychological and somatic outcome of the illness. In clinical practice, to screen out maladaptive reactions and to effectively plan the psychological interventions, we need measuring tools that can be applied among a wide range of patients and can measure the illness-related emotional and cognitive representations in detail.

Aim: The aim of our study was to examine the applicability of the drawing test version (PRISM-D) we developed from the Pictorial Representations of Illness and Self Measure test and its posttest in clinical practice among cancer patients. 
Method: We applied the Pictorial Representations of Illness and Self Measure drawing test and its posttest for 150 cancer patients undergoing hospital treatment.

Results: According to the quantitative data from the tests, patients underwent considerable suffering from illness, however, there was a large heterogeneity in the level of suffering in the sample. The majority of the patients in the sample associated negative feelings to their illness, such as distress, fear, sadness, uncertainty. As for illness representations, they interpreted their illness as a sign, a difficulty, a task to solve, a struggle, a loss, an adversity or a personal failure. The size and placement of the circle symbolizing the illness can be used to identify patient reactions to deny or understate illness as well as patients who experience their illness very seriously. This information is crucial in the understanding of illness behavior and the coping with illness.

Conclusions: Our study has supported this test as a measuring tool which is well applicable to quickly gain complex information both in clinical practice and in research, to measure illness-related emotional and cognitive representations, both quantitatively and qualitatively.

Keywords: illness perception, coping, psychological test, drawing, cancer patients

Sándor Z, Csabai M. [Application of the PRISM-D drawing test to the complex examination of cancer-related emotional and cognitive representations]. Orv Hetil. 2018; 159(48): 2021-2030.

(Beérkezett: 2018. május 4.; elfogadva: 2018. június 3.)

\section{Rövidítések}

$\mathrm{IPM}=$ (Illness Perception Measure) betegségpercepció; PRISM = Pictorial Representations of Illness and Self Measure teszt; PRISM-D = (Drawing version of Pictorial Representations of Illness and Self Measure) a Pictorial Representations of Illness and Self Measure teszt rajztesztverziója; SD = standard deviáció; SIS = (Self-Illness Separation $)$ Én-betegség távolság

Egy súlyos betegség a páciensek számára nem csupán testi, hanem számos lelki és szociális változással is együtt jár. A betegség következtében fellépó változásokra adott pszichés reakció, a betegség lelki megélése, valamint a betegséggel kapcsolatos mentális reprezentációk befolyásolhatják a rövid és hosszú távú testi, lelki és szociális felépülést [1-3].

A daganatos betegséggel való szembesülés a betegek többsége számára traumatikus esemény [4]. A diagnózissal való szembesülést követően gyakori reakció a lelki összeomlás, illetve a tudattalan elhárító mechanizmusok megjelenése [5]. A betegség vagy annak súlyosságának tagadása, elhárítása átmenetileg, a diagnózissal való szembesülés szakaszában csökkentheti ugyan az egyén lelki szenvedését, elnyomhatja szorongását, így rövid távon kedvező hatású lehet. A tartósan fennálló tagadás azonban, különösen a betegséggel való megküzdés időszakában, nagyon negatív következményekkel járhat, azon túl ugyanis, hogy megszakíthatja a stresszt keltő esemény lelki feldolgozásának folyamatát, gátolhatja az orvossal való együttmúködést vagy akár a gyógykezelésben való részvételt [6].

A betegségre adott érzelmi reakciók közül fontos szerepe van az emelkedett mértékü distressznek és szorongásnak, melyek negatívan befolyásolhatják a betegséghez való adaptációt, a megküzdését és akár a betegség lefo- lyását [7]. Lényeges az is, hogy a betegek milyennek látják betegségüket, miként értelmezik, intepretálják és értékelik azt. Ugyanis a betegség szubjektív percepciója, a beteg által kialakított egyedi betegségkép, betegségreprezentáció, illetve a betegség kimenetelével kapcsolatos elvárások szintén befolyásolják a páciensek megküzdéses válaszait és betegségviselkedését, így közvetve hatást gyakorolnak a betegség lefolyására $[8,9]$.

A kutatások és a tapasztalat ugyanakkor azt mutatja, hogy a betegség lelki megélése, illetve percepciója egyedi, még azonos betegpopuláción belül is nagy egyéni változatosságot mutat [10]. Éppen ezért szükséges az egyes betegek egyéni, szubjektív viszonyulásának vizsgálata, és maladaptív reakciók esetén egyénre szabott pszichés intervenció során módosítani a gyógyulást potenciálisan hátráltató lelki tényezőket.

Bár napjainkban számos mérôeszköz áll rendelkezésre a betegséggel kapcsolatos érzelmi és kognitív válaszok mérésére (például szorongás, depresszió, stressz, betegségreprezentáció, betegségteher), ezen mérőeszközök csak részben illeszthetôk a mindennapi klinikai gyakorlatba. Többségük csak jól verbalizáló, megfelelően együttmúködő személyek esetében alkalmazható, mely kritériumok súlyos betegséggel küzdő személyek esetében - akár a betegség tünetei, akár annak kezelése miatt - nem mindig teljesülnek. Továbbá, mivel a mérőeszközök többsége egy-egy szúk lelki dimenziót vizsgál, a beteg pszichés állapotának és kognícióinak feltárása több mérőeszköz alkalmazását teszi szükségessé, melyek felvétele és kiértékelése idő- és energiaigényes, és nem felel meg a klinikai környezet speciális jellegéből fakadó elvárásoknak.

A szomatikus betegek esetében a klinikai és kutatási tapasztalatok azt mutatják, hogy a különböző nonverbális technikák, mint például a vizuális skálák, rajztesztek, 
sok esetben hatékonyabban alkalmazhatók a betegek lelki dimenzióinak vizsgálatára, mint a hagyományos papírceruza alapú pszichológiai tesztek. Egyrészt ugyanis nehezen verbalizáló betegek esetében is jól alkalmazhatók, másrészt kevesebb energiaráfordítást igényelnek, és mindezek mellett lehetőséget nyújtanak a nem tudatos érzések, gondolatok feltárására is [11-14].

Tapasztalataink alapján a súlyos állapotú szomatikus betegekkel végzett egészségpszichológiai tevékenység során a kvantitatív adatokat nyújtó mérőeszközök alkalmazásán túl olyan komplex mérőeszközre van szükség, melynek segítségével viszonylag kevés idő- és energiaráfordítással széles körű információhoz juthatunk a beteg pszichés állapotáról és a betegség szubjektív megéléséről. Korábbi vizsgálataink alapján a Büchi és Sensky által 1998-ban kidolgozott és a klinikai gyakorlatban nemzetközileg alkalmazott PRISM (Pictorial Representations of Illness and Self Measure) nonverbális teszt általunk kifejlesztett rajztesztverziója (PRISM-D teszt) jól alkalmazható a páciensek betegséggel összefüggő reprezentációinak mérésére [15-18]. Az eredeti PRISM teszt olyan egyszerü vizuális technika, mely egy dimenziót: a betegség következtében megélt szenvedés mértékét tárja fel [19]. A teszt további módosított verziói képet nyújtanak a betegségpercepcióról (PRISM-RI teszt) [20], illetve a betegség és bizonyos tényezők (például betegség és család, munka, hobbi stb.) viszonyáról (PRISM+ teszt) [21, 22].

Az általunk kifejlesztett PRISM-D rajzteszt a korábbi PRISM tesztek előnyeit megtartva, a tesztek által vizsgált dimenziók differenciáltabb mérését teszi lehetővé $[23,24]$. A rajzteszttel részletesen tovább vizsgálható a betegségnek a páciens életébe való ágyazottsága, a személy aktuális életterének résztvevői és a gyógyulást potenciálisan segítő, illetve gátló tényezők. A PRISM-D teszt, utótesztjével kiegészítve, képes komplex képet nyújtani a betegségnek a személyre gyakorolt szubjektív hatásáról és a betegség egyéni értelmezéséről. Korábbi tapasztalataink alapján a módszer további előnye, hogy a páciens aktív részvételét kívánja a tesztfelvétel során, serkenti a kommunikációt, és alkalmas a terápiás folyamat alatti információgyưjtésre és utánkövetésre [18].

Jelen tanulmányunk célja annak vizsgálata volt, hogy a PRISM-D rajzteszt, valamint az ehhez kapcsolódó utóteszt hogyan alkalmazható a klinikai gyakorlatban, súlyos fekvő betegek esetében. Vizsgálatunk során ismertetni kívánjuk, hogy a PRISM-D teszt segítségével milyen módokon mérhetők a betegséggel összefüggő érzelmi és kognitív reprezentációk, kitérve a rajzteszten és az annak utótesztjén nyerhető kvantitatív és kvalitatív adatok elemzési lehetőségeire. További célunk az utóteszt hasznosságának vizsgálata, az ebből nyerhető információk komplexitásának demonstrálása, valamint az utóteszten nyerhető adatok elemzési lehetőségeinek bemutatása aktív kórházi kezelés alatt álló daganatos betegpopuláció példáján keresztül.

\section{1. melléklet | PRISM-D-instrukció vizsgálatvezetők számára}

Kedves Hölgyem/Uram!

Szeretnénk jobban megérteni, hogy betegsége hogyan hat a jelenlegi életére. Itt egy fehér papir. (A vizsgált személyeknek úgy kell odaadnia a lapot, hogy a sárga kör az ő perspektívájából jobbra lent legyen.) Képzelje el, hogy ez a lap az életterét jelenti, ez a sárga kör pedig Önt szimbolizálja. Most arra kérem, hogy ezzel a piros filccel rajzolja le betegségét, ugyanúgy egy koronggal/körrel szimbolizálva azt, oda, ahová a leginkább el tudja helyezni Önmagáboz képest. (Piros filcet adok a kezébe, lerajzolja, elveszem tőle, megköszönöm.) Elakadás esetén további instrukció, ha szükséges: Gondolkodjon el rajta, mennyire befolyásolja életét a betegség, mennyire érzi nehéznek a tüneteit.

Most arra kérem, hogy rajzolja le minden olyan fontos területét az életének, ami eszébe jut (ha rákérdez, hogy mire is gondolok, akkor megjegyzem: például család, munka, hobbi, bármi, ami különös jelentőséggel bír az Ön számára) - ezek a szinek állnak rendelkezésére. Arra kérem, hogy ugyanúgy kör vagy korong alakjában jelenitse meg az Ön számára fontos tényezőket.

Elakadás esetén további instrukció: Gondolkodjon $\mathrm{el}$, mi az, ami még fontos Önnek, és eddig nem rajzolta le. Mi hiányzik még erről a képröl?

Utóteszt: Ez a kör mit jelez az Ön életében?

Közben felírom a jelölőlapra a színekhez a sorszámot és azok jelentését (utóteszt), illetve a tapasztalt különleges reakciókat (dünnyögés, elakadás stb.). Jelöljük azt is, ha kiszínezte a kört: a szín mellett zárójelben egy nagy $\mathbf{S z}$-szel, tehát „piros $(\mathrm{Sz})$ ”. Továbbá Á jel, ha átfed a sárgával, és $\mathbf{H}$ betú, ha hozzáér a sárgához.

A jelek a szín oszlopban:

Sz = beszínezett kör; Á = átfed a sárgával; $\mathrm{H}$ = hozzáér a sárgához

\section{Módszer}

\section{A résztvevoók és a vizsgálat körülményei}

A vizsgálatban 150 fő, kórházi kezelés alatt álló daganatos beteg vett részt. Az alábbi daganattípusban szenvedő személyek vettek részt a vizsgálatban: emlötumoros, gyomor-bél rendszeri daganatos, vérképző szervi daganatos, melanoma malignumos, méhnyakrákos, hererákos és tüdődaganatos betegek. A betegek $81,3 \%$-a nő, 18,7\%-a férfi volt. Az átlagéletkor 56 év volt (SD = $13,68)$.

$\mathrm{Az}$ adatfelvételt pszichológus, illetve viselkedéselemző szakemberek végezték a Szegedi Tudományegyetem Szent-Györgyi Albert Klinikai Központjában, a Békés Megyei Központi Kórház Pándy Kálmán Tagkórházában, valamint a budapesti Országos Onkológiai Intézetben. Az adatfelvétel időtartama körülbelül 15 perc volt.

\section{Méröeszköz}

A PRISM-D teszt a PRISM teszt [19] általunk korábban kifejlesztett rajztesztváltozata [18], melynek esetében egy A/4-es fehér lapon kell a személynek megjelenítenie 
\begin{tabular}{l|l} 
2. melléklet & PRISM-D tesztfelvételi adatlap
\end{tabular}

Nem:

Kor:

Diagnózis:

Osztály:

A tesztfelvétel dátuma:

Felvette:

\begin{tabular}{|c|c|c|c|c|c|c|}
\hline Sorrend & Szín & Méret & Távolság & Jelentés & Különleges reakció & Utóteszt \\
\hline 1. & $\begin{array}{l}\text { Piros } \\
\text { SZ-H-Á }\end{array}$ & $\begin{array}{l}\mathrm{r}=\longleftarrow \mathrm{cm} \\
\mathrm{T}=\longleftarrow \mathrm{cm}^{2}\end{array}$ & $\mathrm{~s}=\ldots \mathrm{cm}$ & Betegség & & \\
\hline 2. & SZ-H-Á & $\begin{array}{l}\mathrm{r}=\mathrm{cm}_{\mathrm{T}}=\mathrm{cm}^{2} \\
\mathrm{~cm}^{2}\end{array}$ & $\mathrm{~s}=\ldots \mathrm{cm}$ & & & \\
\hline 3. & SZ-H-Á & $\begin{array}{l}\mathrm{r}=\longleftarrow \mathrm{cm} \\
\mathrm{T}=\longleftarrow \mathrm{cm}^{2}\end{array}$ & $\mathrm{~s}=\ldots \quad \mathrm{cm}$ & & & \\
\hline 4. & SZ-H-Á & $\begin{array}{l}\mathrm{r}=\longleftarrow \mathrm{cm} \\
\mathrm{T}=\longleftarrow \mathrm{cm}\end{array}$ & $\mathrm{s}=\ldots \mathrm{cm}$ & & & \\
\hline 5. & SZ-H-Á & $\begin{array}{l}\mathrm{r}=\longleftarrow \mathrm{cm} \\
\mathrm{T}=\longleftarrow \mathrm{cm}^{2}\end{array}$ & $\mathrm{~s}=\_\mathrm{cm}$ & & & \\
\hline 6. & SZ-H-Á & $\begin{array}{l}\mathrm{r}=\ldots \mathrm{cm} \\
\mathrm{T}=\longleftarrow \mathrm{cm}^{2}\end{array}$ & $\mathrm{~s}=\ldots \mathrm{cm}$ & & & \\
\hline 7. & SZ-H-Á & $\begin{array}{l}\mathrm{r}=\mathrm{cm} \\
\mathrm{T}=\longleftarrow \mathrm{cm}^{2}\end{array}$ & $\mathrm{~s}=\_\mathrm{cm}$ & & & \\
\hline 8. & SZ-H-Á & $\begin{array}{l}\mathrm{r}=\longleftarrow \mathrm{cm} \\
\mathrm{T}=\longleftarrow \mathrm{cm}^{2}\end{array}$ & $\mathrm{~s}=\ldots \mathrm{cm}$ & & & \\
\hline 9. & SZ-H-Á & $\begin{array}{l}\mathrm{r}=\longleftarrow \mathrm{cm} \\
\mathrm{T}=\longleftarrow \mathrm{cm}^{2}\end{array}$ & $\mathrm{~s}=\ldots \mathrm{cm}$ & & & \\
\hline 10. & SZ-H-Á & $\begin{array}{l}\mathrm{r}=\longleftarrow \mathrm{cm} \\
\mathrm{T}=\square \mathrm{cm}^{2}\end{array}$ & $\mathrm{~s}=\ldots \mathrm{cm}$ & & & \\
\hline 11. & SZ-H-Á & $\begin{array}{l}\mathrm{r}=\longleftarrow \mathrm{cm} \\
\mathrm{T}=\longleftarrow \mathrm{cm}^{2}\end{array}$ & $\mathrm{~s}=\ldots \mathrm{cm}$ & & & \\
\hline 12. & SZ-H-Á & $\begin{array}{l}\mathrm{r}=\ldots \mathrm{cm} \\
\mathrm{T}=\square \mathrm{cm}^{2}\end{array}$ & $\mathrm{~s}=\ldots \quad \mathrm{cm}$ & & & \\
\hline 13. & SZ-H-Á & $\begin{array}{l}\mathrm{r}=\mathrm{cm} \\
\mathrm{T}=\square \mathrm{cm}^{2}\end{array}$ & $\mathrm{~s}=\ldots \mathrm{cm}$ & & & \\
\hline 14. & SZ-H-Á & $\begin{array}{l}\mathrm{r}=\ldots \mathrm{cm} \\
\mathrm{T}=\longleftarrow \mathrm{cm}^{2}\end{array}$ & $\mathrm{~s}=\ldots \quad \mathrm{cm}$ & & & \\
\hline 15. & SZ-H-Á & $\begin{array}{l}\mathrm{r}=\ldots \mathrm{cm} \\
\mathrm{T}=\longleftarrow \mathrm{cm}^{2}\end{array}$ & $\mathrm{~s}=\ldots \mathrm{cm}$ & & & \\
\hline
\end{tabular}

A jelek a szín oszlopban:

Sz = beszínezett kör; Á = átfed a sárgával; $\mathrm{H}$ = hozzáér a sárgához

r = a berajzolt kör sugara; $s$ = a berajzolt kör középpontja és az Ént szimbolizáló kör középpontja között mért távolság; T = a berajzolt kör területe 
a betegségét egy általa piros filctollal rajzolt kör segítségével. A teszten a fehér lap a személy aktuális életterét szimbolizálja, a lap jobb alsó sarkában pedig egy előre nyomtatott, $7 \mathrm{~cm}$ átmérőjü sárga kör található, mely a személy Énjét szimbolizálja. Az instrukció szerint (1. melléklet) a vizsgálatban részt vevő személy elsőként a betegségét rajzolja be a tesztlapra, szabadon, méret és elhelyezkedésbeli megkötés nélkül [18]. A korábbi verziók elemzési metodikáját megtartva, a PRISM-D teszten az Ént és a betegséget szimbolizáló kör középpontjai közötti távolság, az úgynevezett Self-Illness Separation (SIS) [19] utal a betegség okozta szubjektív szenvedés mértékére. A berajzolt betegség mérete pedig az úgynevezett Illness Perception Measure (IPM) [20], mely a betegségpercepcióra utal.

A PRISM-D teszt második részében a vizsgálatban részt vevő személyek tetszőleges színü filctollak segítségével megjeleníthetik az életterükben aktuálisan jelen lévő, számukra fontos tényezőket. Ez alapján képet kaphatunk a személy életterének komplexitásáról, a gyógyulásban szerepet játszó protektív és hátráltató tényezőkrôl.

A tesz harmadik részében, az utóteszt során, a vizsgálatvezető külön erre szolgáló adatlapon feljegyzi a berajzolt körök jelentését. Továbbá feljegyzi az esetlegesen előforduló különleges reakciókat (sírás, zavartság, düh kifejezése stb.). Az egyes berajzolt körökre vonatkozóan megkérdezi, hogy mit jelent a vizsgálatban részt vevó személy számára az adott tényező. A válaszokat az adatlapon rögzíti (2. melléklet).

\section{Adatelemzés}

Az adatelemzés során egyrészt az Én-betegség távolság (Self-Illness Separation, SIS) került kiszámításra, melyet az Ént és a betegséget szimbolizáló körök középpontjai

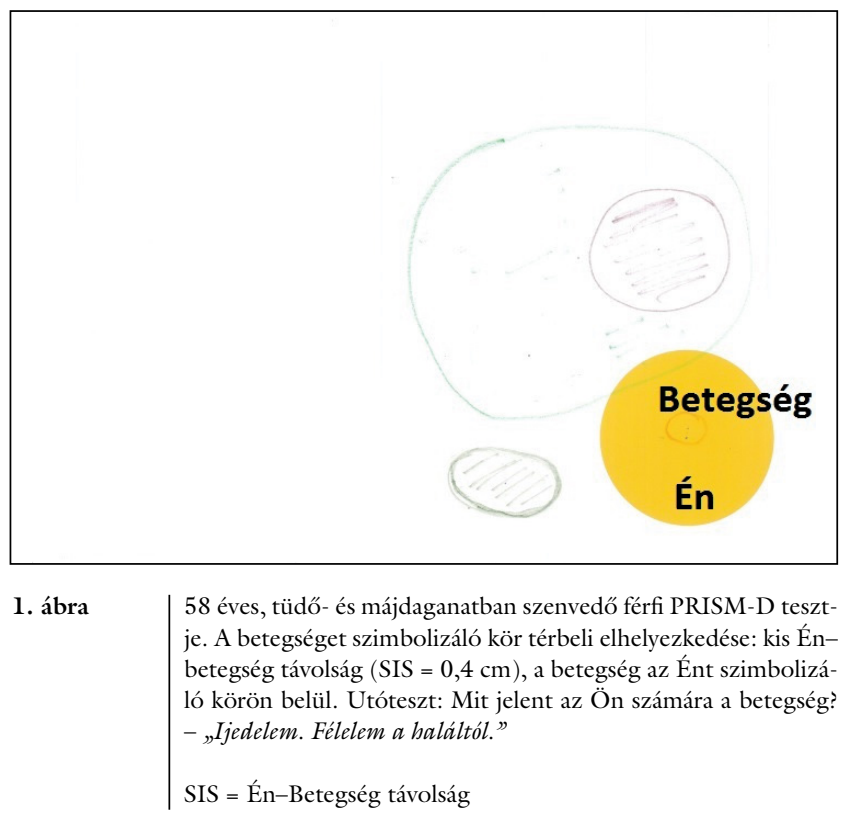

között mérünk. Másrészt kiszámoltuk a berajzolt, betegséget szimbolizáló kör területét (Illness Perception Measure, IPM). Ezt követte az értékek leíró statisztikai elemzése (átlag, szórás), valamint a berajzolt körök kategorizálása. A betegségen kívüli egyéb megjelenített körök (Gyógyulás, Egészség) tekintetében válaszmegoszlások kerültek meghatározásra (százalék).

Az utóteszten nyert szöveges adatokat a tartalomelemzés módszerével vizsgáltuk. A válaszokat jelentéstartalmuk alapján kategorizáltuk. A kategóriákat két független kódoló hozta létre. Az adatelemzés során a kategóriák előfordulási gyakoriságát százalékos formában tüntettük fel. Az utótesztek kvalitatív elemzését a jelen vizsgálatban a Betegség, Gyógyulás és Egészség körök jellemzői szerint végeztük.

\section{Eredmények}

\section{$A$ betegségre adott reakció}

\section{A betegséget szimbolizáló kör térbeli elhelyezkedése alapján}

A betegség Éntől való térbeli elhelyezkedése az Én-betegség viszonyra utal. A térbeli pozíciót tekintve a vizsgálatban részt vevő személyek 18,8\%-a jelenítette meg a betegséget az Énen belül, 6,7\%-uk az Énhez hozzáérve, $74,5 \%$-uk pedig az Énen kívül.

Az Ént és a betegséget szimbolizáló körök középpontja közötti távolság (SIS) alapján a minta egészére nézve nagyfokú betegségtől való szenvedés jellemző $(M=10,62 ; S D=8,13)$. A magas szórásérték az eredmények nagyfokú heterogenitására, a megélés egyéni változatosságára utal. A legkisebb felvett érték $0 \mathrm{~cm}$, a legnagyobb 28,9 volt. A teszten megjelenített, betegséget szimbolizáló körök térbeli pozícióját szemlélteti az 1. és a 2. ábra.

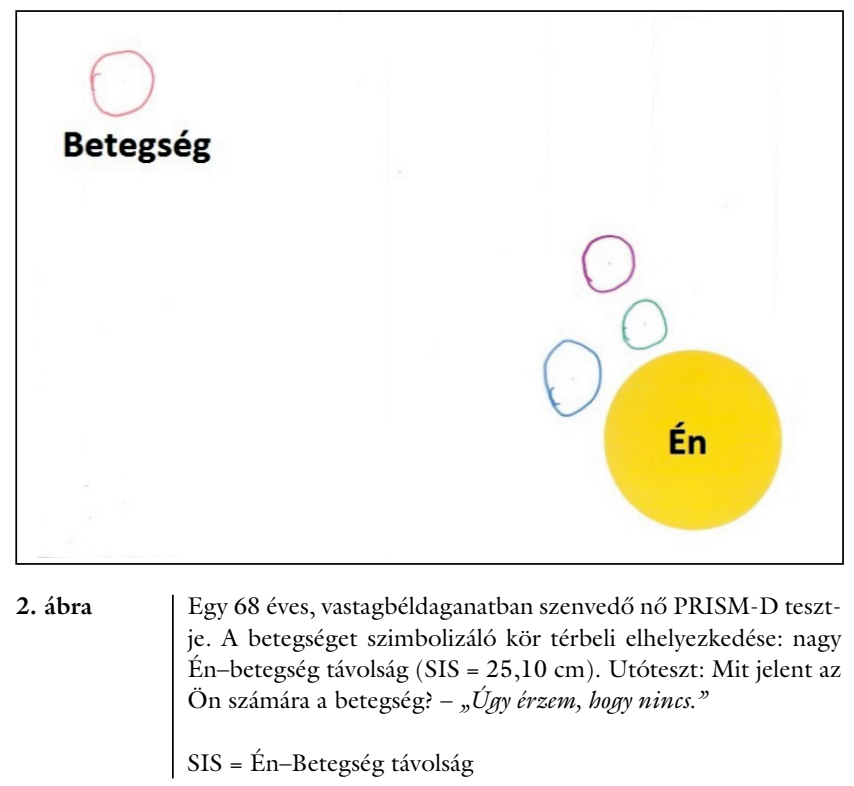


A PRISM-D-utóteszt Betegségre vonatkozó válaszainak kvalitatív elemzése alapján a betegségre adott reakciók válaszkategóriáinak \%-os megoszlása, illetve példamondatok

\begin{tabular}{lll}
\hline Kategória & $\begin{array}{l}\text { Előfordulás } \\
\text { gyakorisága (\%) }\end{array}$ & Példa \\
\hline $\begin{array}{l}\text { Negatív érzelem, } \\
\text { distressz, katasztrofizálás }\end{array}$ & 27,3 & "Lelkileg összetört.” \\
\hline $\begin{array}{l}\text { Tagadás, hárítás, Éntől } \\
\text { való távolítás }\end{array}$ & 14 & $\begin{array}{l}\text { „Úgy érzem, hogy } \\
\text { nincs”, „Mintha ez } \\
\text { velem nem történt } \\
\text { volna meg.” }\end{array}$ \\
\hline $\begin{array}{l}\text { Megküzdés, problémafó- } \\
\text { kuszú és megoldáskereső } \\
\text { hozzállás }\end{array}$ & 16 & $\begin{array}{l}\text { „Leküzdhet”, tehát le } \\
\text { fogom küzdeni, egy } \\
\text { leküzdhetó gond.” }\end{array}$ \\
\hline $\begin{array}{l}\text { Énbe való integrálás } \\
4\end{array}$ & $\begin{array}{l}\text { "Ez most nagyon } \\
\text { meghatározza az } \\
\text { életem, nagyon bennem } \\
\text { van.” }\end{array}$ \\
\hline Elfogadás & 2,7 & $\begin{array}{l}\text { Eleinte rossz volt, } \\
\text { most elfogadtam, } \\
\text { együtt élek vele.” }\end{array}$ \\
\hline
\end{tabular}

A teszten a kisebb Én-betegség távolság a szenvedés fokozott megélésére utal, a nagyobb távolság pedig alacsonyabb fokú lelki szenvedést jelez. A vizsgált minta 16\%-ánál volt megfigyelhető szélsőségesen nagy Én-betegség távolság (SIS>20 cm), mely a vizsgálatban részt vevő személyek aktuális szomatikus állapotát figyelembe véve a betegség elhárítására enged következtetni.

\section{A betegséget szimbolizáló körhöz kapcsolódó utóteszt alapján}

A PRISM-D teszt utótesztjének tartalomelemzése során a válaszok $64 \%$-ában találtunk betegségre adott reakcióra utaló tartalmat. A válaszokban a leggyakrabban a negatín érzelmi reakció, a fokozott mértékü distressz, illetve a katasztrofizálás jelent meg (27,3\%). A válaszok 14\%-a utal a betegség tagadására, háritására, az Éntől való távolítására. A betegek 16\%-ánál a betegséggel való megküzdés vagy valamilyen konkrét megküzdéses válaszra utaló tartalom, illetve a betegséghez való problémaorientált hozzáállás került megfogalmazásra. A válaszok 4\%-ában a betegség Énbe való integrálását fogalmazták meg, mely arra utal, hogy a betegség a személy részévé vált. További 2,7\%-ában megjelent a betegség elfogadása (1. táblázat).

\section{A betegséggel kapcsolatos reprezentációk}

\section{A betegséggel kapcsolatos érzelmi reprezentációk}

A betegséget szimbolizáló körhöz kapcsolódó utóteszt válaszainak 43\%-ában kerültek említésre a betegséggel kapcsolatos érzelmi reprezentációk, melyből 40,9\% negatív érzelmi reakcióra utal. A válaszoknak csupán 2,1\%ában került megfogalmazásra pozitív vagy semleges érze- lem a betegséggel kapcsolatban. Az összes utóteszt 11,3\%-ában általánosságban rossz érzést fogalmaztak meg, 8,7\%-ában distresszt, 4,4\%-ában félelmet, 2,7\%ában szomorúságot, 2,7\%-ában meglepetést, 2\%-ában bizonytalanságot. 2\%-nál alacsonyabb gyakorisággal említett érzelmi tartalmak voltak: tehetetlenség, kilátástalanság, lelkiismeret-furdalás, lelki sokk.

\section{Betegségpercepció - A betegséget szimbolizáló kör} mérete alapján

A betegséget szimbolizáló kört a vizsgálatban részt vevők átlagosan kisebbnek jelenítették meg, mint az Ént szimbolizáló kört. A berajzolt betegséget szimbolizáló körök mérete átlagosan $12,75 \mathrm{~cm}^{2}$-es méretű volt (IPM), a nagy szórásérték $(S D=24,57$ ) azonban nagy egyéni változatosságra utal. A legnagyobb méretű kör 254,46

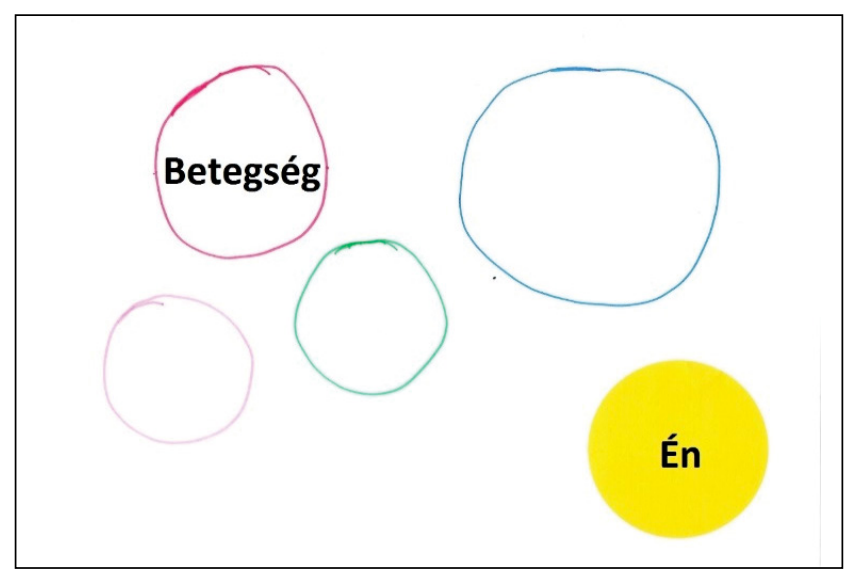

3. ábra

Egy 68 éves, emlőtumorban szenvedő nő PRISM-D tesztje. A betegséget szimbolizáló kör mérete nagy (IPM $=38,47 \mathrm{~cm}^{2}$ ). Utóteszt: Mit jelent az Ön számára a betegség? - „A betegség rosszul érintett.”

IPM = betegségpercepció

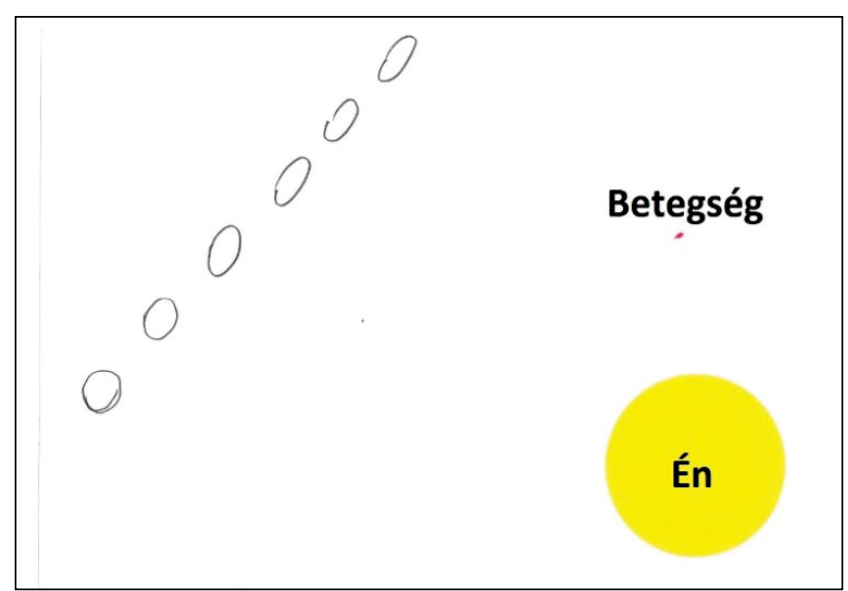

4. ábra

Egy 43 éves, emlőtumorban szenvedő nő PRISM-D tesztje. A betegséget szimbolizáló kör mérete kicsi $\left(\mathrm{IPM}=0,08 \mathrm{~cm}^{2}\right)$. Utóteszt: Mit jelent az Ön számára a betegség? - „Szeretnék túl lenni a betegségen. Gyógyulást.”

IPM = betegségpercepció 
$\mathrm{cm}^{2}$ volt, mely $9 \mathrm{~cm}$ átmérőjü körre utal, a legkisebb pedig $0,01 \mathrm{~cm}^{2}$, ami valójában egy pici pont. A vizsgálatban részt vevők 42\%-a $1 \mathrm{~cm}$ átmérőjünél kisebbnek jelenítette meg a betegségét $\left(3,14 \mathrm{~cm}^{2}\right.$ területü kör).

Összességében a megkérdezettek $88,7 \%$-a jelenítette meg az Énnél kisebbnek a betegségét, 6,7\%-uk a betegséggel közel azonos méretűként. A betegek 4,7\%-ánál azonban a betegség „nagyobb”, mint az Én. Az egyes teszteken megjelenített, betegséget szimbolizáló körök közötti nagyfokú eltéréseket a 3. és a 4. ábra mutatja.

\section{Betegségpercepció - A betegséget szimbolizáló kör- höz kapcsolódó válaszok az utóteszt alapján}

Az utótesztek 36\%-ának esetében találtunk betegségreprezentációra utaló választartalmat. Az ezen szempontból kategorizálható válaszok között a leggyakoribb reprezentáció a betegség jelzésként való interpretálása volt $(31,5 \%)$. A második leggyakoribb kategória a betegség gátként, akadályként való megélése volt $(25,9 \%)$. Gyakori válaszkategória volt továbbá a betegség megoldandó feladatként való interpretálása (18,5\%). A válaszadók $5,55 \%$-a a betegséget a küzdelemmel azonosítja. A betegség lefolyása szempontjából kedvezőtlenebb válaszkategóriák a betegség veszteségként $(7,4 \%)$, csapásként $(5,55 \%)$ vagy személyes kudarcként $(5,55 \%)$ való interpretálása (2. táblázat).

A betegség szimbólumként való megjelenítése során a betegséget „derült égből villámcsapásként”, „pofonként” fogalmazták meg.

2. táblázat |A PRISM-D utótesztjének Betegségre vonatkozó kérdésében megfogalmazott betegséginterpretáció-kategóriák típusai, százalékos megoszlásuk és példamondatok

\begin{tabular}{|c|c|c|}
\hline Kategória & $\begin{array}{l}\text { Előfordulás } \\
\text { gyakorisága } \\
(\%)\end{array}$ & Példa \\
\hline $\begin{array}{l}\text { Jelzés, } \\
\text { változás }\end{array}$ & 31,50 & $\begin{array}{l}\text { „Rádöbbentett arra, hogy mit } \\
\text { rontottam el. Új irányban kell } \\
\text { haladnom.” } \\
\text { „Szükséges rossz, amivel megváltozta- } \\
\text { tom az életem és a gondolkodásom.” }\end{array}$ \\
\hline $\begin{array}{l}\text { Gát, akadály, } \\
\text { teher }\end{array}$ & 25,90 & $\begin{array}{l}\text { „Elég nagy teher. Ezt kaptam a sorstól, } \\
\text { el kell viselni.” } \\
\text { „Hátráltató tényező.” }\end{array}$ \\
\hline Feladat & 18,50 & $\begin{array}{l}\text { „Probléma, amit meg kell oldani.” } \\
\text { „Megoldandó feladat." }\end{array}$ \\
\hline Veszteség & 7,40 & $\begin{array}{l}\text { „Elvesztegetett idő.” } \\
\text { „Mindent háttérbe szorít.” } \\
\text { „Karrier kettétörése.” } \\
\text { „Sok mindenben korlátoz, felborítja az } \\
\text { életem.” }\end{array}$ \\
\hline Csapás & 5,55 & $\begin{array}{l}\text { "Pofon, egészségesen éltem az életem, } \\
\text { derült égból villámcsapás.” }\end{array}$ \\
\hline Küzdelem & 5,55 & „Küzdeni akarok, amíg lehet.” \\
\hline Kudarc & 5,55 & $\begin{array}{l}\text { „Kudarc, mindig vigyáztam az } \\
\text { egészségemre.” }\end{array}$ \\
\hline
\end{tabular}

\section{A betegség kimenetelével kapcsolatos reprezentációk}

A betegséget szimbolizáló körhöz kapcsolódó utóteszt válaszainak 16\%-ában találhatunk a betegség kimenetelére utaló választartalmakat. A betegség kimenetelével kapcsolatos válaszok többsége $(91,87 \%)$ a betegség pozitív irányú változásával kapcsolatos gondolatokat tartalmazott (gyógyulásba vetett hit, pozitív jövőbeli változások). Csupán az ilyen tartalmú válaszok 8,13\%-ában, az összes válasz 1,3\%-ában találhatunk negatív kimenetellel kapcsolatos választartalmakat (a betegség rosszabbodása, halál és az ezektől való félelem).

A megkérdezettek 13,4\%-a jelenítette meg a PRISMD teszten a gyógyulását egy külön körrel. Az utótesztre adott válaszok („Mit jelent az Ön számára a gyógyulás?”) a gyógyulás fontosságára és az azzal kapcsolatos hitre, vágyra és célra vonatkoztak. A vizsgálatban részt vevő személyek 14,6\%-a tüntette fel a teszten külön körrel az egészségét. Az utóteszt válaszaiban az alábbi tartalmak jelentek meg („Mit jelent az Ön számára az egészség?”): az egészség fontosságának hangsúlyozása; az egészség mint élet; az egészség mint boldogság; az egészség mint elérendő cél (3. táblázat).

\section{Megbeszélés}

Vizsgálatunk során a PRISM-D teszt és utótesztje klinikai alkalmazhatóságának bemutatását tüztük ki célul. Eredményeink szerint a méróeszköz részletes és komplex, ugyanakkor könnyen és gyorsan alkalmazható klinikai környezetben. A teszt egyaránt nyújt kvantitatív és kvalitatív információt a betegséggel összefüggő reprezentációkról és a betegségre adott reakciókról. A PRISM-D

\section{3. táblázat | A PRISM-D teszten Gyógyulást, illetve Egészséget szimbolizáló körök megjelenítési aránya (\%), illetve a fentiekhez kapcsolódó utótesztekre adott válaszok jelentéskategóriái példamondatok- kal}

\begin{tabular}{lll}
\hline & Gyógyulás & \\
\hline Megjelenítette (\%) & 13,4 & \\
\hline Jelentése & Érték & „A legfontosabb az életemben.” \\
& Cél & „Ez a legfontosabb cél, hogy \\
& helyreálljon minden.” \\
& Hit & „Hiszek benne, de nehéz.” \\
& Vágy & „Szeretnék gyógyulni.” \\
& Csoda & „Egy csoda lenne.” \\
\hline Egészség & \\
\hline Megjelenítette (\%) & 14,6 & \\
\hline Eelentése & Érték & „A legfontosabb, akkor jövünk \\
& Élet & "Az életemet.” \\
& Boldogság & „Boldogságot.” \\
& Cél & „Elérendő cél.”
\end{tabular}


rajzteszt és annak utótesztje a teszt korábbi verzióihoz képest a szubjektív reprezentációk differenciált feltárását teszi lehetővé. A teszten megjelenített, betegséget szimbolizáló kör térbeli elhelyezkedésének és méretének értelmezésén túl az utóteszt segítségével részletes, több szempontból elemezhető kvalitatív információt kaphatunk.

A teszten megjelenített, betegséget szimbolizáló kör térbeli elhelyezkedésének kvantitatív értékelésével, az Én-betegség távolság (SIS) elemzésével feltárható a betegség nyomán fellépő szenvedés mértéke csakúgy, mint az eredeti PRISM teszten [19]. Eredményeink szerint a teszten megjelenített betegség Éntől való távolsága alapján a megkérdezett személyekre általánosságban a betegségtől való nagymértékű szenvedés jellemző. A SIS-érték nagymértékű szórása azonban arra utal, hogy a vizsgált betegek által megélt szenvedés mértéke nagy egyéni változatosságot mutat.

A betegséget szimbolizáló körnek az Ént szimbolizáló körhöz képest a tesztlapon elfoglalt térbeli pozíciója utalhat a betegség tagadására vagy távolítására nagy ÉnBetegség távolság esetében (jellemzően olyan esetekben, amikor a betegséget szimbolizáló kör az Éntől a lap lehető legtávolabbi pontján helyezkedik el, a bal felső sarokban). A térbeli pozíció értelmezésekor azonban mindig figyelembe kell venni a páciens aktuális fizikális állapotát, ugyanis a nagy távolság az Én és a betegség között gyógyult állapotban vagy javulás esetén adaptív válasznak tekinthető. Súlyos betegség akut szakaszában azonban az Éntől való távolításként, szélsőségesen nagy távolság esetében pedig akár tagadásként értelmezendő, mely, amennyiben tartósan fennálló reakcióként van jelen, gátolhatja a betegséggel való sikeres megküzdést. A jelen betegpopuláció esetében, mivel a betegek az adatfelvétel időpontjában súlyos krónikus betegség aktív kezelése alatt álltak, a betegség ilyen típusú ábrázolása a betegség elhárításaként értelmezendő, mely a vizsgálatban részt vevők 16\%-ánál volt megfigyelhető.

A betegség és az Én egymáshoz viszonyított térbeli elhelyezkedése továbbá jelezheti a betegség Énbe való beépítését, integrációját is abban az esetben, ha a betegséget a páciens az Ént szimbolizáló körön belül vagy azzal átfedésben jeleníti meg. Ilyen esetben a személy a betegséget önmaga részeként éli meg. Ez a típusú megjelenítés a megkérdezett betegek 18,8\%-ánál volt megfigyelhető, további 6,7\%-uk pedig a betegséget az Énhez hozzáérve jelenítette meg, ami szintén jelzi a betegség önmagához való közelségét.

A teszten berajzolt, betegséget szimbolizáló kör méretéből következtetni tudunk a betegség szubjektíve megélt „nagyságára”, mely a teszt korábbi verziói alapján [20] a betegségpercepcióra utal. Eredményeink szerint a betegség szubjektíve megélt mérete nagyfokú egyéni eltérést mutat a vizsgált mintán belül, ugyanis a legkisebb megjelenített kör $0,01 \mathrm{~cm}$ átmérőjü, a legnagyobb $9 \mathrm{~cm}$ átmérőjű volt. A berajzolt betegség mérete a betegséggel való megküzdés szempontjából fontos információt nyújt.
A nagyon kicsi méret azt szimbolizálja, hogy a páciens a betegségét kicsinek éli meg, ami súlyos szomatikus állapot esetében a betegség bagatellizálására is utalhat. A nagyméretúnek megjelenített betegség pedig utal arra, hogy a betegség uralja a személy életterét, és kérdéses lehet, hogy rendelkezésre áll-e a személy számára annyi erőforrás, melynek segítségével sikeresen megküzdhet a betegséggel és az abból adódó kihívásokkal.

Hasznos információt nyújthat annak értelmezése, hogy milyen a betegséget szimbolizáló körnek az Ént szimbolizáló körhöz viszonyított mérete, mely megmutatja, hogy a beteg a betegségét szubjektíve önmagához képest „mekkorának”, milyen súlyosnak, milyen jelentősnek éli meg. Az Énnél nagyobb kör jelzi, hogy a páciens a betegségét önmagánál „nagyobb” ágensként szemléli, melynek „legyőzése” önerőből nehezebb lehet, így a megküzdés szempontjából kedvezőtlenebb kimenetelre utal. Ez a típusú ábrázolás a vizsgálatban részt vevő személyek 4,6\%-ánál volt megfigyelhető. 6,6\%-uk az Énnel közel azonos méretünek jelenítette meg a betegségét, 88,8\%-uk pedig kisebbnek.

Eredményeink szerint a fenti elemzéseket jól kiegészítik az utótesztre adott válaszok. Egyrészt megerősítik a betegséget szimbolizáló kör méretéből és térbeli elhelyezkedéséből nyert eredményeket, másrészt annál differenciáltabb információt is nyújtanak a szakember számára. A betegségre vonatkozó utótesztben, a „Mit jelent az Ön számára a betegség?” kérdésre megfogalmazott válaszok nagy egyéni változatosságot mutatnak, ami utal arra, hogy a módszer alkalmas az egyéni reakciók, érzések és értelmezések feltárására. A válaszok többnyire komplexek, a betegséggel és annak megélésével kapcsolatban többféle információt is tartalmaznak. A tartalomelemzés eredményei szerint a válaszok több kategória mentén is jól elemezhetők.

A betegséget szimbolizáló körhöz kapcsolódó utóteszt válaszainak $64 \%$-ában találhatunk a betegségre adott reakciókra utaló választartalmat, úgymint negatív érzések megélése/érzelmi reakció, tagadás/elhárítás, a betegséghez való problémaorientált hozzáállás, a betegség elfogadása és a betegség Énbe való integrációja. A válaszok $43 \%$-ában találhatók a betegséggel kapcsolatos érzésekre vonatkozó tartalmak, melyek 98\%-a negatív érzelmi reprezentációt tartalmaz. A leggyakrabban említett érzelmi reprezentációk a distressz, a félelem, a szomorúság, a meglepetés, a bizonytalanság és az általánosan rossz érzés voltak.

A válaszok 36\%-ában találunk a betegségreprezentációra, a betegség szubjektív értelmezésére, interpretálására utaló válaszokat. A vizsgált betegek esetében a betegség jelzésként, feladatként, akadályként, veszteségként, csapásként, küzdelemként, kudarcként való megélése jelent meg. A válaszok relatíve kevés, csupán 16\%-a utalt a betegség kimenetelére, mely válaszok többsége a betegség pozitív kimenetelével kapcsolatos hitre, vágyra utalt. A betegség kimenetelével kapcsolatos nézetekre utalnak továbbá az opcionálisan berajzolt, gyógyulást vagy 
egészséget szimbolizáló körök. A gyógyulást a betegek 13,4\%-a, az egészséget 14,6\%-a jelenítette meg külön körrel, ami ezeknél a betegeknél utal ezen tényezők szubjektív fontosságára.

\section{Következtetések}

Elmondható, hogy eredményeink szerint a PRISM-D teszt és annak utótesztje alkalmas a betegséggel kapcsolatos egyéni reakciók és kogníciók feltárására. Az eljárás előnye, hogy a tesztfelvétel gyors, egyszerü, ennek ellenére rendkívül komplex képet nyújt a betegség egyénre gyakorolt szubjektív hatásáról. A PRISM-D rajzteszt az eredeti PRISM teszt előnyeit megtartva, azt továbbfejlesztve differenciált képet nyújt súlyos betegeknek a betegségtől való szenvedésérôl és betegségpercepciójáról. A vizuális eszköz egyszerü adatfelvételt tesz lehetővé klinikai környezetben, súlyos fekvő betegek esetében. A teszt nonverbális jellege miatt akár verbálisan nehezen hozzáférhető betegek esetében is alkalmazható.

Jelen vizsgálatunk a PRISM-D utótesztjének hasznosságára hívja fel a figyelmet. Eredményeink szerint az utótesztre adott válaszok jól kiegészítik a rajzteszt során nyert információkat, ezáltal a betegséggel kapcsolatos érzelmi és kognitív reprezentációk komplex feltárását teszik lehetővé.

A PRISM-D teszt és annak utótesztje jól alkalmazható a klinikai egészségpszichológiai tevékenység során szürőtesztként, a klinikai szempontból tovább vizsgálandó reakciók detektálására is. Ugyanakkor alkalmas az egyénvagy csoportmunka során a terápiás folyamat részét képező feltáró eszközként a terápiás folyamat megtervezésére, illetve az állapotváltozás nyomon követésére. A kvantitatív adatok elemzése pedig lehetővé teszi a nagy mintán végzett összehasonlító vizsgálatok kivitelezését.

Anyagi támogatás: A közlemény megírása, illetve a kapcsolódó kutatómunka anyagi támogatásban nem részesült.

Szerzői munkamegosztás: S. Z.: A kutatás megtervezése, adatgyüjtés, az adatok statisztikai értelmezése, a publikáció megírása. Cs. M.: A kutatási terv kidolgozása, az eredmények értelmezése, a kézirat megírásában nyújtott segítség. A cikk végleges változatát mindkét szerző elolvasta és jóváhagyta.

Érdekeltségek: A szerzőknek nincsenek érdekeltségeik.

\section{Köszönetnyilvánítás}

Szeretnénk köszönetet mondani a kutatást segítő kollégáinknak, $D r$. Látos Melindának és Dr. Kovács Péternek.

\section{Irodalom}

[1] Hagger M, Orbell S. A meta-analytic review of the commonsense model of illness representations. Psychol Health 2003; 18 : 141-184.

[2] Anagnostopoulos F, Spanea E. Assessing illness representations of breast cancer. A comparison of patients with healthy and benign controls. J Psychosom Res. 2005; 58: 327-334.

[3] Petrie KJ, Jago LA, Devcich DA. A role of illness perceptions in patients with medical conditions. Curr Opin Psychiatry 2007; 20: 163-167.

[4] Rohánszky M, Berényi K, Fridrik D, et al. Effectiveness of mindfulness-based cancer recovery (MBCR) program among Hungarian cancer patients. [Éber, tudatos figyelemre épülö, a rákbetegséggel való megküzdést segítő program (MBCR) hatásvizsgálata magyar rákbetegek körében.] Orv Hetil. 2017; 158: 1293-1301. [Hungarian]

[5] Muszbek K, Gaal I. Pitfalls within the cancer-related doctor-patient communication. [Az orvos-beteg kommunikáció csapdái daganatos betegség esetén.] Orv Hetil. 2016; 157: 649-653. [Hungarian]

[6] Kreitler S. Denial in cancer patients. Psychosocial issues. Cancer Invest. 1999; 17: 514-534.

[7] McGregor BA, Antoni MH. Psychological intervention and health outcomes among women treated for breast cancer: a review of stress pathways and biological mediators. Brain Behav Immun. 2009; 23: 159-166.

[8] Weinman J, Petrie KJ. Illness percepctions: a new paradigm for psychosomatics? J Psychosom Res. 1997; 42: 113-116.

[9] Büssing A, Fischer J. Interpretation of illness in cancer survivors is associated with health-related variables and adaptive coping styles. BMC Women's Health 2009; 9: 2.

[10] Leventhal H, Leventhal EA, Cameron L. Representations, procedures, and affect in illness self-regulation: a perceptual-cognitive model. In: Baum A, Revenson TA, Singer JE. (eds.) Handbook of Health Psychology. Erlbaum, Mahwah, NJ, 2001; pp. 19-47.

[11] de C Williams AC, Davies HT, Chadury Y. Simple pain rating scales hide complex idiosyncratic meanings. Pain 2000; 85: 457463.

[12] Houts PS, Witmer JT, Egeth HE, et al. Using pictographs to enhance recall of spoken medical instructions II. Patient Educ Couns. 2001; 43: 231-242.

[13] Broadbent E, Ellis CJ, Gamble G, et al. Changes in patient drawings of the heart identify slow recovery after myocardial infarction. Psychosom Med. 2006; 68: 910-913.

[14] Látos M, Barabás K, Lázár G, et al. Mental representations of the new organ and posttransplant patients' anxiety as related to kidney function. Transplant Proc. 2012; 44: 2143-2146.

[15] Havancsák R, Kovács P, Látos M, et al. Application of the PRISM drawing test to explore the illness representations and the factors facilitating coping of hospital inpatients: first Hungarian observations. In: Vargha A. (ed.) The human face of science: XXIth National Scientific Congress of the Hungarian Psychological Association: Abstract book. [A PRISM rajzteszt alkalmazása kórházi betegek reprezentációinak és a megküzdést segítő tényezők feltárására: Első hazai tapasztalatok. In: Vargha A. (szerk.) A tudomány emberi arca: A Magyar Pszichológiai Társaság XXI. Országos Tudományos Nagygyúlése: Kivonatkötet.] Magyar Pszichológiai Társaság, Szombathely, 2012; p. 311. [Hungarian]

[16] Havancsák R, Kovács P, Látos M, et al. Observations of the first Hungarian application of the PRISM-D drawing test for hospital inpatients with cancer. In: Barabás K, Kapocsi E, Pikó B. (eds.) XIIth Behavioral Sciences Days: Program and abstracts. [A PRISM 
nonverbális teszt első hazai alkalmazásának tapasztalatai kórházi osztályokon fekvő daganatos betegekkel. In: Barabás K, Kapocsi E, Pikó B. (szerk.) XII. Magatartástudományi Napok: Programfüzet és absztraktok kivonata.] JATEPress Kiadó, Szeged, 2012; p. 72. [Hungarian]

[17] Pócza-Véger P, Havancsák R, Látos M, et al. Visualization of illness representations of hospital patients by the use of the PRISMD drawing test. In: Kővágó P, Vass Z, Vargha A. (eds.) IInd National Applied Psychology Conference of $\mathrm{PhD}$ Students: Abstracts. [Kórházi betegek betegségreprezentációinak megjelenítése a PRISM-D rajzteszt használatával. In: Kővágó P, Vass Z, Vargha A. (szerk.) II. Országos Alkalmazott Pszichológiai PhD-Hallgatói Konferencia: Előadás-kivonatok.] Károli Gáspár Református Egyetem, Budapest, 2013; p. 32. [Hungarian]

[18] Havancsák R, Pócza-Véger P, Csabai M. The PRISM-D drawing test in the examination and treatment of hospital patients. In: Csabai M, Pintér JN. (eds.) Psychology in healing: Phenomenological, art psychological and body representation centered approaches. [A PRISM-D rajzteszt kórházi betegek vizsgálatában és kezelésében. In: Csabai M, Pintér JN. (szerk.) Pszichológia a gyógyításban. Fenomenológiai, művészetpszichológiai és testkép-központú megközelítések.] Oriold és Társai Kiadó, Budapest, 2013; pp. 83-107. [Hungarian]

[19] Büchi S, Sensky T. PRISM: Pictorial Representation of Illness and Self Measure. A brief nonverbal measure of illness impactand therapeutic aid in psychosomatic medicine. Psychosomatics 1999; 40: 314-320.

[20] Reimus JL, Vingerhoets AJ, Soons PH, et al. Suffering in psoriasis patients: its relation with illness severity and subjective wellbeing. Int J Dermatol. 2007; 46: 1042-1045.

[21] Büchi S, Sensky T, Sharpe L, et al. Graphic representation of illness: a novel method of measuring patients' perceptions of the impact of illness. Psychother Psychosom. 1998; 67: 222-225.
[22] Niedermann K, Büchi S, Ciurea A, et al. Six and 12 months' effects of individual joint protection education in people with rheumatoid arthritis: A randomized controlled trial. Scand J Occup Ther. 2012; 19: 360-369.

[23] Sándor Z, Csabai M. Complex examination of illness representations of patients with breast cancer. In: Koncz I, Szova I. (eds.) (More) Authentical scientific presentations, vol. 2. PEME (Association of Professors for the European Hungary) VIIIth PhD Conference. [Emlődaganatos betegek betegségreprezentációinak több szempontú vizsgálata. In: Koncz I, Szova I. (szerk.) Hiteles(ebb) tudományos prezentációk, II. kötet: PEME VIII. PhD-Konferencia.] Professzorok az Európai Magyarországért Egyesület, Budapest, 2014; pp. 26-37. [Hungarian]

[24] Sándor Z, Czinderi K, Csabai M. Connections between illness representations, postoperative pain and social support on the PRISM-D nonverbal test in case of newly operated patients with breast cancer. In: Vargha A. (ed.) The world of our relationships: XXII. National Scientific Congress of the Hungarian Psychological Association: Abstract book. [Betegségreprezentációk, mútét utáni fájdalom és társas támogatás összefüggései a PRISMD nonverbális teszten frissen operált emlődaganatos betegeknél. In: Vargha A. (szerk.) Kapcsolataink világa: Magyar Pszichológiai Társaság XXII. Országos Tudományos Nagygyúlés: Kivonatkötet.] Magyar Pszichológiai Társaság, Budapest, 2013; p. 265. [Hungarian]

\section{„Dum spiro, spero." (Amíg élek, remélek.)}


Annex 2: Publications providing the basis of the thesis

III. Sándor Z, Látos M, Csabai M. Észlelt társas támogatás összefüggéseinek vizsgálati lehetőségei a PRISM-D rajzteszt segítségével kórházi kezelés alatt álló súlyos betegek körében. Orvosi Hetilap. 2020;161(39): 1688-1696. IF: 0,497** 


\title{
Az észlelt társas támogatás összefüggéseinek vizsgálati lehetőségei a PRISM-D rajzteszt segítségével kórházi kezelés alatt álló súlyos betegek körében
}

\author{
Sándor Zita ${ }^{1,2}$ - Látos Melinda dr. ${ }^{3,4}$ - Csabai Márta dr. ${ }^{3}$ \\ ${ }^{1}$ Szegedi Tudományegyetem, Általános Orvostudományi Kar, Klinikai Orvostudományok Doktori Iskola, Szeged \\ ${ }^{2}$ Gál Ferenc Fớiskola, Egészség és Szociális Tudományi Kar, Gyula \\ ${ }^{3}$ Szegedi Tudományegyetem, Általános Orvostudományi Kar, Pszichológiai Intézet, Szeged \\ ${ }^{4}$ Szegedi Tudományegyetem, Általános Orvostudományi Kar, Sebészeti Klinika, Szeged
}

Bevezetés: Kórházi betegek körében a betegség okozta változások miatt a társas kapcsolatok átrendeződhetnek, erősödhetnek, de akár gyengülhetnek is. Ezen változások mérése, a szubjektíve megélt társas támogatás mértékének, elérhetőségének vagy akár az észlelt izolációnak a kimutatása fontos feladat, ugyanis ezen dimenziók összefüggnek a gyógyulási mutatókkal.

Célkitüzés: A kutatás célja annak bemutatása, hogy az általunk fejlesztett PRISM-D rajzteszt hogyan alkalmazható az észlelt társas támogatás mérésére. További célkitűzés a teszten mért társas támogatás mutatóinak és a depresszió-, valamint a szorongásszint közötti kapcsolatnak a vizsgálata súlyos betegek esetében.

Módszer: 194 súlyos, kórházi kezelés alatt álló beteg (daganatos, mútéti beavatkozást igénylő gyomor-bél rendszeri betegségben és krónikus veseelégtelenségben szenvedő betegek) esetében a PRISM-D rajzteszt, a STAI- és BDItesztek felvétele kórházi osztályokon.

Eredmények: A vizsgálati személyek többsége megjelenítette a rajzteszten a társas támogatást $(95,7 \%)$, jelentős hányaduk több körrel (64,0\%) és nagyobbnak, mint a betegséget szimbolizáló kör (71,2\%). Azok a személyek, akik nem jelenítettek meg egyetlen társas támogató személyt sem, szignifikánsan magasabb szorongásszintet éltek meg (STAI-S: $\mathrm{p}=0,040, \mathrm{df}=18 \mathrm{l} ; \mathrm{STAI}-\mathrm{T}: \mathrm{p}=0,005, \mathrm{df}=153)$. A térbeli elhelyezkedést tekintve azok a betegek, akik az Ént és a betegséget szimbolizáló kör közé helyezték el a társas támogatást, alacsonyabb szintû́ szorongást és depresszív tüneteket éltek meg, mint akik a betegséget rajzolták közelebb, a társas támogatást távolabb (STAI-S: p = 0,016, $\mathrm{df}=91 ; \mathrm{BDI}: \mathrm{p}=0,027, \mathrm{df}=142$ ).

Következtetés: Eredményeink szerint a PRISM-D rajzteszt alkalmas az észlelt társas támogatás vizsgálatára, az Énhez és a betegséghez viszonyított szubjektív jelentőségének és észlelt közelségének mérésére, továbbá az észlelt szociális izoláció detektálására. Gyors, egyszerű mérőeszközként nagymértékben segítheti kórházi osztályokon a szűrést és a terápiás munkát.

Orv Hetil. 2020; 161(39): 1688-1696.

Kulcsszavak: társas támogatás, pszichológiai teszt, rajzolás

\section{Using PRISM-D drawing test for the examination of associations of perceived social support among inpatients with chronic medical conditions}

\footnotetext{
Introduction: Changes caused by illness can lead to a reorganization, either strengthening or weakening social relationships among hospitalized patients. Measuring these changes, and the detection of the extent and availability of perceived social support or even of the perceived isolation is an important task, as these dimensions are related to disease outcomes.

Aim: The aim of the research is to demonstrate the applicability of the PRISM-D drawing test developed by us to measure perceived social support. A further objective is to examine the relationship between test social support measures and depression and anxiety levels of severely ill patients.

Method: The PRISM-D drawing test, STAI and BDI tests were used among 194 patients (with tumor, gastrointestinal illness requiring surgery and chronic renal failure) in hospital wards.
} 
Results: The most test subjects drew circles representing social support on the test $(95.7 \%)$; most of them drew more circles $(64.0 \%)$ and of larger size $(71.2 \%)$ than the circle symbolizing the illness. Individuals who did not display anyone as source of social support experienced significantly higher levels of anxiety (STAI-S: $\mathrm{p}=0.040, \mathrm{df}=181$; STAI-T: $\mathrm{p}=0.005, \mathrm{df}=153$ ). In terms of spatial location, patients who placed social support between the Self and the circle symbolizing illness experienced lower levels of anxiety and depressive symptoms than those drawing the illness closer and social support farther (STAI-S: $\mathrm{p}=0.016, \mathrm{df}=91$; BDI: $\mathrm{p}=0.027, \mathrm{df}=142$ ).

Conclusion: According to our results, the PRISM-D drawing test is suitable for examining perceived social support, measuring its relative significance and perceived proximity to the Self and the illness, and detecting perceived social isolation. As a quick, simple measurement tool, it can greatly help screening and therapeutic work in hospital wards.

Keywords: social support, psychological test, drawing

Sándor Z, Látos M, Csabai M. [Using PRISM-D drawing test for the examination of associations of perceived social support among inpatients with chronic medical conditions]. Orv Hetil. 2020; 161(39): 1688-1696.

(Beérkezett: 2020. április 2.; elfogadva: 2020. április 22.)

\section{Rövidítések}

BDI $=($ Beck Depression Inventory $)$ Beck Depresszió Kérdőív; $\mathrm{df}=$ szabadsági fok; FACT $=($ functional assessment of cancer therapy) a rákterápia funkcionális értékelése; HIV = (human immunodeficiency virus) emberi immunhiányt előidéző vírus; IPM = (illness perception measure $)$ a betegségpercepciót méró érték; $M=$ átlag; PRISM = Pictorial Representations of Illness and Self Measure; PRISM-D = (drawing version of PRISM $)$ a PRISM rajztesztverziója; $\mathrm{SD}=$ (standard deviáció) szórás; SIS $=($ Self-illness separation $)$ Én-betegség távolság; STAI = (State-Trait Anxiety Inventory) Spielberger-féle Vonás- és Állapotszorongás Kérdőív; STAI-S = a STAI 'állapotszorongás' alskálája; STAI-T = a STAI 'vonásszorongás' alskálája

A társas támogatás nagyon fontos tényező súlyos testi betegséggel való megküzdés során. Egy betegség ugyanis számos testi, lelki és szociális kihívás elé állítja az egyént, melyek próbára tehetik a személy teherbíró képességét. Számtalan tanulmány igazolta, hogy az ilyen nehéz élethelyzetekben a jól múködő társas támogatás, azaz a szignifikáns/jelentôs mások (például család, barátok, ismerősök) által biztosított pszichoszociális erőforrások [1] jelenléte számos pozitív következménnyel jár [2].

Vizsgálati eredmények alapján a magasabb szintû társas támogatást észlelő személyek lelkileg jobban viselik a betegséggel járó változásokat, mely összefüggést többek között szívbetegek, diabeteses, HIV-fertőzött, daganatos és rheumatoid arthritisben szenvedő betegek esetében is kimutatták [3-7]. Más kutatási eredmények arra hívják fel a figyelmet, hogy a magasabb szintű társas támogatás mútét utáni alacsonyabb fájdalommal és jobb kezeléskimenettel jár együtt súlyos betegek esetében [8, 9], általánosságban pedig elmondható, hogy pozitívan befolyásolja a morbiditási, mortalitási és életminőségmutatókat krónikus betegséggel küzdő személyeknél [10].
A társas támogatás általános egészségre gyakorolt pozitív hatásának hatásmechanizmusára vonatkozóan több elmélet született. Egyrészt a társas támogatás direkt fiziológiai hatása révén kedvezően befolyásolja a cardiovascularis, endokrin és immunrendszert, ezáltal jótékony hatást gyakorolva a gyógyulási folyamatra [11]. A napjainkban népszerü stresszpufferelmélet szerint (Theory on Stress Buffering) a társas támogatás azáltal fejti ki pozitív hatását, hogy képes a negatív stressz hatásait felfogni, pufferelni, és a stressz-szint csökkentése révén járul hozzá a pozitív egészségi kimenetelekhez [12]. Továbbá közvetett hatásként a társas támogatás pozitív hatással bír a mentális egészségre, például csökkenti a pszichológiai distressz és a depresszió kialakulásának kockázatát [13-16]. A depresszív tünetekre gyakorolt kedvező hatásának hátterében egyrészt direkt hatásról beszélhetünk, a társas támogató személyek érzelmi és funkcionális támogatásának biztosítása révén, másrészt észlelt erőforrásként hat azáltal, hogy a személyek nem érzik izoláltnak és magányosnak magukat $[17,18]$.

Mindezek mellett a megfelelő társas támogatás segítségével a beteg információt, segítséget és érzelmi támogatást kaphat, ami hozzájárulhat a betegség elfogadásához és a megfelelő megküzdéshez [11, 19]. Az, ahogyan a családtagok reagálnak a betegségre, valamint a betegség kezelésébe való bevonódásuk, részvételük nagymértékben befolyásolhatja a betegek egészségvédő viselkedését és így a betegség kimenetelét is [20, 21]. Ezek mellett a társas támogató személyek erôsíthetik a betegben azt az érzést, hogy fontos számukra, és érdemes meggyógyulnia [22], ami célt adhat a betegnek.

Fontos figyelembe venni, hogy egy súlyos betegség és annak következményei átstrukturálhatják a társas kapcsolatokat, erősíthetik, de akár gyengíthetik is azokat [23]. A társas kapcsolatok számára kihívást jelent a betegség diagnózisa, kezelése és lefolyása [24, 25]. Számos tanulmány kimutatta, hogy a krónikus betegséggel élő személyeknek kevesebb társas kapcsolatuk van, mint az egészséges személyeknek [26-28]. Vizsgálatok szerint a 
leginkább a barátokkal és az ismerősökkel való kapcsolatok korlátozódnak, a partnerrel és gyermekkel való kapcsolatra azonban többnyire nem gyakorol a betegség ilyen negatív hatást, ső́t ezek a kapcsolatok akár fokozódhatnak, erősödhetnek [29].

Sokszor azonban a betegség kezelése vezet ahhoz, hogy akár átmenetileg, akár tartósan a betegek szociális izolációt, magányosságot élnek meg, ugyanis gyakran vagy a betegség fizikai tünetei, vagy a kezelés miatt korlátozódik a családdal és a barátokkal való kapcsolattartás (például intenzív osztályos ellátás, karantén). A betegek sok esetben kénytelenek egyedül szembenézni a betegségük okozta teherrel. A megélt szociális izoláció, magányosság azonban nem kedvező, vizsgálati eredmények szerint ugyanis negatív egészségkimenetelekkel jár együtt [30].

Szem előtt kell azonban tartani azt, hogy az izoláció megélése nagyon szubjektív, csakúgy, mint az, hogy a személy milyen mértékű és jellegú támogatást vár el a társas közegtől, ráadásul ezek a betegséglefolyás során akár jelentősen változhatnak. Egyedi az is, hogy a személy a potenciálisan rendelkezésre álló támogató kapcsolatokat és az objektíve érkező társas támogatási formákat miként észleli és értékeli. A támogató tényezők egyéni sajátosságokkal bíró érzékelése [2] az ún. észlelt társas támogatás, mely a személyek egyedi észlelési, értékelési és memóriafolyamatainak következményeként jön létre. Kutatási eredmények alapján ez a szubjektív kép jár együtt a kedvező egészségkimenetelekkel, és nem az objektíve rendelkezésre álló kapcsolatok száma [31, 32]. Éppen ezért a társas támogatás vizsgálata során fontos ezt a dimenziót vizsgálni.

A társas támogatás tehát kiemelten fontos tényező a gyógyulás szempontjából, ugyanakkor a jelenség komplexitása miatt a mérése nem könnyú. A legtöbb méróeszköz önkitöltős, papír-ceruza teszt, melyek nem teszik lehetôvé a társas támogató tényezők szubjektív fontosságának, a személyekhez való tudattalan viszonyulásuknak a feltárását. Ezen dimenziók vizsgálata azonban lényeges információkkal járulhat hozzá a személy társas kapcsolatainak feltérképezéséhez, valamint az egyénre szabott pszichés intervenció előkészítéséhez.

Az intervenciós kutatások eredményei szerint ugyanis a társas támogatás fejlesztésére, javítására irányuló pszichoszociális intervenciók potenciálisan hozzájárulhatnak a betegek pozitívabb egészségi állapotához [33, 34]. Ahhoz azonban, hogy az intervenció szükségességére egyáltalán fény derüljön, nélkülözhetetlen a beteg kapcsolataihoz való szubjektív viszonyulásának feltárása, illetve az esetlegesen megjelenő észlelt izoláció detektálása. Érdemes figyelembe venni továbbá azt is, hogy a hagyományos papír-ceruza tesztek relatíve nagy energiaráfordítást és jól múködő verbális készségeket igényelnek a páciensektől, melyek bizonyos gyógyítási helyzetekben nem vagy csak korlátozottan állnak rendelkezésre.

$\mathrm{Az}$ általunk fejlesztett PRISM-D rajzteszt egy olyan nonverbális eszköz, mely lehetővé teszi a betegséggel küzdő személyek aktuális életterében jelen levő fontos tényezők feltárását [35-37]. Az eredeti PRISM-tesztverzió egy olyan vizuális mérőeszköz, mely a betegség okozta tehernek, a betegség Énre gyakorolt hatásának és a betegségpercepciónak a feltárását teszi lehetővé [38, 39]. A teszt módosított változatainak segítségével az élettér egyéb fontos tényezői is feltárhatók (PRISM+ tesztek) [40], az általunk fejlesztett rajztesztverziója (PRISM-D) pedig lehetôséget ad a betegséggel küzdő személy életterére vonatkozó szubjektív reprezentációk differenciáltabb mérésére [36]. A rajzolás, mint szabad eszköz, projektív jellege miatt ugyanis alkalmas a tudattalan tényezők és viszonyulások feltárására.

Az eredeti PRISM-tesztet eredményesen használták a társas támogatás mérésére, korábbi vizsgálatokban szignifikáns összefüggést találtak a PRISM-en mért észlelt társas támogatás és a FACT-skála 'társas támogatás' alskálája között. Továbbá az észlelt társas támogatás és a fájdalom kapcsolata mindkét mérőeszköz (a PRISM-en megjelenített 'társas támogatás' és a FACT-féle 'társas támogatás' alskála) esetében hasonló eredményeket hozott [41]. Véleményünk szerint a rajztesztverzió segítségével az eredeti teszthez képest további hasznos információk nyerhetők.

Tanulmányunk célja megvizsgálni, hogy a PRISM-D teszt alkalmas-e az észlelt társas támogatás differenciált mérésére, az észlelt szociális izoláció kiszúrésére, valamint a társas támogatás szubjektíve megélt fontosságának vizsgálatára szomatikus betegséggel küzdő személyek esetében. További célunk a teszten megjelenített társas támogatás betegségpercepcióval, depresszió-, illetve szorongásszinttel való összefüggésének megvizsgálása különböző kórházi kezelések alatt álló súlyos testi betegek esetében.

\section{Módszer}

\section{Résztvevők és a vizsgálat körülményei}

A vizsgálatban 194, különböző súlyos szomatikus betegséggel küzdő személy vett részt. A vizsgálati személyek 56,2\%-a daganatos beteg, 13\%-a mútéti beavatkozást igénylő gyomor-bél rendszeri beteg, 30,8\%-a pedig krónikus veseelégtelenségben szenvedő beteg volt. A vizsgálati személyek mindegyike kezelés alatt állt az adatfelvétel ideje alatt.

A betegek átlagéletkora 52,77 év volt (szórás = 14,89). A legfiatalabb résztvevő 14 , a legidősebb 79 éves volt. A megkérdezettek 31\%-a férfi, 68,6\%-a nő volt.

Az adatokat a Szent-Györgyi Albert Klinikai Központban, az Országos Onkológiai Intézetben és a Békés Megyei Központi Kórházban gyújtöttük. Az adatgyüjtés a fenti intézmények támogató hozzájárulásával zajlott a vizsgálati személyek önkéntes beleegyezésével, írásos engedélyével. 


\section{Méröeszközök \\ PRISM-D teszt}

A rajzteszten a vizsgálati személyek egy A/4-es fehér lapra rajzolnak be tetszóleges számú, méretű köröket, melyek a betegségüket és az életterük azon tényezőit szimbolizálják, amelyek aktuálisan fontosak számukra [35-37]. A tesztfelvételi lap jobb alsó sarkában egy $7 \mathrm{~cm}$ átmérőjü, Ént szimbolizáló kör van előre nyomtatva. A teszt első részében a páciensek piros filctollal rajzolják be a betegségüket. Az eredeti teszthez hasonlóan az Én és a betegség távolságának kiszámításával (SIS) mérhető a betegségteher, valamint a 'betegség' kör területének kiszámításával mérhető a betegségpercepció (IPM) [38, 39].

A teszt második részében a vizsgálati személyeknek lehetôségük van szabadon berajzolni az életterük egyéb, számukra aktuálisan fontos tényezőit tetszőleges méretú, színű és elhelyezkedésû körök segítségével. A berajzolt körök jelentését a vizsgálatvezető egy erre szolgáló adatlapon jegyzi fel. A válaszokat az elemzés során jelentéskategóriák alapján lehet csoportosítani. Az utóteszt részben a vizsgálati személyektől megkérdeztük, hogy mit jelentenek számukra azok a tényezők, amelyeket berajzoltak. Ezeket a válaszokat szó szerint rögzíti a vizsgálatvezető. Az így nyert kvalitatív adatok többféle szempont alapján elemezhetők.

Korábbi vizsgálati adataink alapján a teszt második részében megjelenített tényezők közül a leggyakoribbak a társas támogatás kategóriájába sorolható válaszok [36]. A jelen vizsgálatban a szabadon megjelenített körök közül csupán azokat a köröket vizsgáltuk, amelyek jelentéstartalmuk alapján egyértelműen a társas támogatás kategóriájába voltak sorolhatók (például partner, családtag, barát, ismerős, kolléga, szomszéd), és amelyekkel kapcsolatban az utóteszt válaszai alapján is megerósítést nyert, hogy érzelmi és/vagy instrumentális támaszt jelentenek a személyek számára. A válaszok kategorizálása két független kódoló bevonásával történt, melynek során kiemelt figyelmet fordítottunk a társas támogatás jelentéstartalmainak egyértelmű meghatározására.

Az elemzés során mértük az Én és a társastámogatás távolságot, illetve amennyiben a személy több körrel ábrázolta a társas támogatás tagjait, a legközelebb ábrázolt társas támogató tényezőnek az Éntől való távolságát. Ezen mutatók az észlelt társas támogatás közelségére, elérhetőségére utalhatnak. A teszten mérhetővé válik a megjelenített társas támogató tényezők mérete, terület $\left(\mathrm{cm}^{2}\right)$ is, mely az észlelt társas támogatás nagyságát szimbolizálhatja. Továbbá mérhető a társas támogatás és a betegség viszonya, kapcsolata, egymáshoz viszonyított méretük, elhelyezkedésük. A tesztet, valamint a mért mutatókat szemlélteti az 1 ábra.

\section{STAI}

A betegek szorongásszintjének mérésére a Spielbergerféle Vonás- és Állapotszorongás Kérdőívet (STAI) alkal-

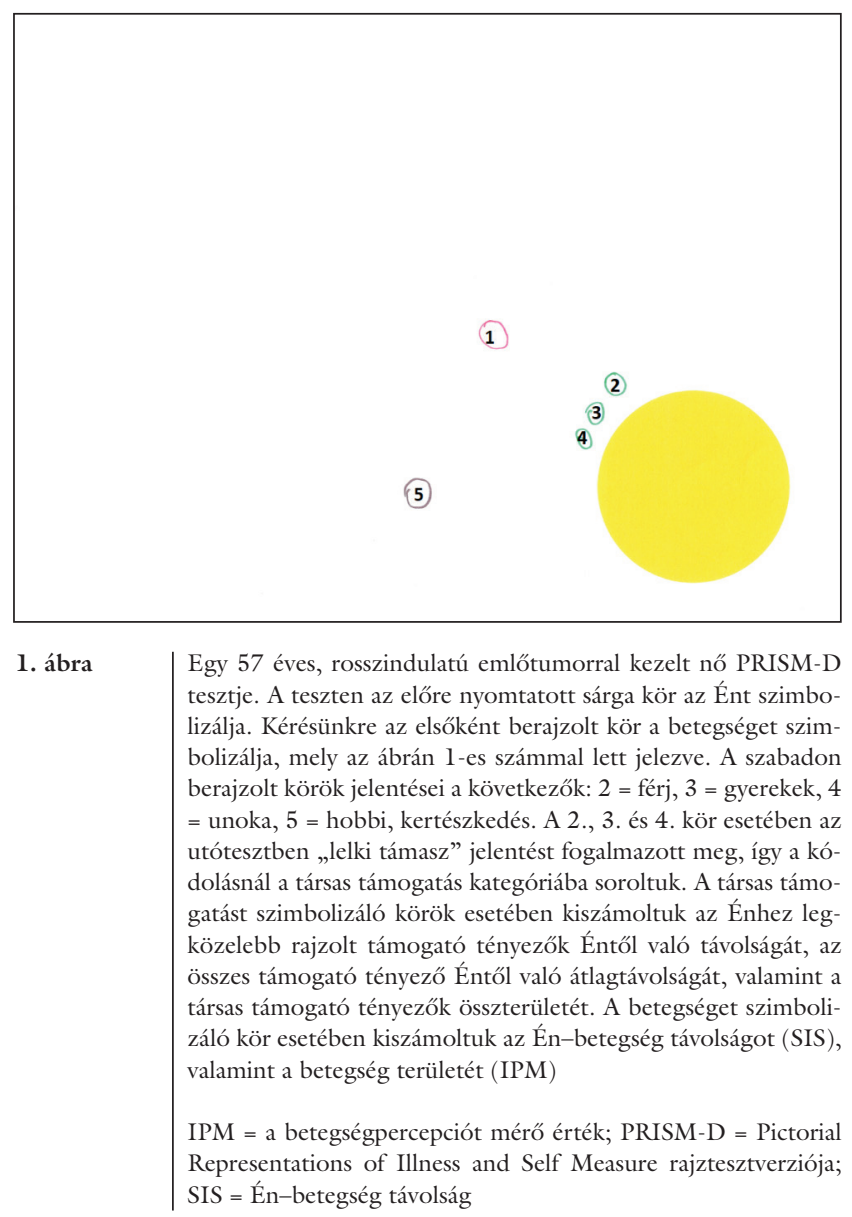

maztuk [42, 43]. A mérőeszköz lehetővé teszi az ún. 'vonásszorongás', vagyis a személyre jellemző általános szorongásszint mérését (STAI-T), valamint az aktuálisan megélt, ún. 'állapotszorongás' (STAI-S) vizsgálatát. Mindkét alskála 20 itemből áll. A válaszokat 1-tôl 4-ig kell értékelni, így a skálák összpontszáma 20 és 80 közötti értéket vehet fel, amelynél a magasabb pontszám fokozott szorongásos tünetek jelenlétére utal. A kérdőiv reliabilitása megfelelő (Cronbach-alfa $=0,77$ ).

\section{BDI}

A páciensek depressziószintjét a Beck-féle Depresszió Kérdőív 21 itemes változatával mértük fel [44-46]. A kérdőívben minden kérdéscsoportnál 4 állítás közül kell eldönteni a vizsgálati személynek, hogy melyik volt jellemző rá az elmúlt hetekben, napokban. A kiértékeléskor a válaszokat 0 -tól 3-ig pontozzuk, így a teljes skála összpontszáma 0 és 84 közötti értéket vehet fel, amelynél a magasabb érték fokozottabb depresszív tünetek jelenlétére utal. A skála belső érvényessége megfelelő.

\section{Adatelemzés}

A statisztikai elemzést az SPSS 21-es verziójának (IBM, Armonk, NY, USA) használatával készítettük. A leíró statisztikák ismertetéséhez átlagértékek, szórásértékek és 
válaszmegoszlások kerültek kiszámításra. A társas támogatás és a hangulati változók kapcsolatának vizsgálata során Student-féle t-tesztet alkalmaztunk.

\section{Eredmények}

\section{Az észlelt társas támogatás megjelenitése}

A PRISM-D teszten a résztvevők 95,7\%-a jelenítette meg a családját vagy annak bizonyos tagját, tagjait. Csupán 4,3\%-uk nem jelenített meg családtagot, sem egyéb társas támogató személyt a PRISM-en, ami az aktuálisan észlelt szociális izolációra utalhat. A betegek 72,7\%-a jelenített meg a családon túl egyéb társas támogató személyeket, például barátokat, kollégákat, szomszédokat. A betegek 36\%-a egy körrel ábrázolta a társas támogatást, 64\%-uk viszont több kör berajzolásával jelenítette meg a számára fontos tényezőket.

A megjelenített társas támogatás összterülete 36,99 $\mathrm{cm}^{2}$ volt $(\mathrm{SD}=52,93)$, mely minimálisan kisebb, mint a teszten megjelenített, Ént szimbolizáló kör területe $\left(38,48 \mathrm{~cm}^{2}\right)$, és nagyobb, mint a vizsgálati személyek által megjelenített betegség területének átlaga $(\mathrm{M}=16,29$ $\left.\mathrm{cm}^{2}, \mathrm{SD}=33,11\right)$. Bár ez utóbbi eredmény arra utal, hogy a vizsgálati személyek átlagosan kisebbnek érezték a betegségük terhét és nagyobbnak a társas támogatást, a nagy szórásértékek nagy egyéni változatosságot jeleznek.

A megjelenített társas támogatás Éntől való távolsága átlagosan $11,10 \mathrm{~cm}$ volt $(S D=5,8)$. Az Én-betegség átlagtávolsághoz képest $(\mathrm{M}=11,59 \mathrm{~cm}, \mathrm{SD}=7,77)$ elmondható, hogy a résztvevők közel azonos távolságra jelenítették meg a betegséget, mint általánosságban a társas támogatást. A nagy szórásértékek azonban nagy egyéni változatosságra utalnak. A megkérdezettek

1. táblázat |A PRISM-D teszten megjelenített betegséget és társas támogatást szimbolizáló körökkel kapcsolatos leíró statisztikák. A PRISM-D teszten megjelenített, betegséget és társas támogatást szimbolizáló körök ábrázolásának gyakorisága, valamint a fenti tényezőknek az Ént szimbolizáló körtől való távolsága és mérete

\begin{tabular}{|c|c|c|c|c|}
\hline & & $\begin{array}{l}\text { Ábrázolta-e? } \\
(\%)\end{array}$ & $\begin{array}{l}\text { Az Éntől } \\
\text { való távolság }\end{array}$ & Mérete \\
\hline Betegség & & $100 \%$ & $\begin{array}{l}M=11,59 \\
(S D=7,77)\end{array}$ & $\begin{array}{l}M=16,29 \\
(S D=33,11)\end{array}$ \\
\hline \multirow{2}{*}{$\begin{array}{l}\text { Társas } \\
\text { támogatás }\end{array}$} & $\begin{array}{l}\text { A } \\
\text { legközelebb } \\
\text { rajzolt } \\
\text { társas } \\
\text { támogató } \\
\text { tényezők }\end{array}$ & \multirow[t]{2}{*}{$95,7 \%$} & $\begin{array}{l}M=9,15 \\
(S D=5,4)\end{array}$ & \multirow{2}{*}{$\begin{array}{l}M=36,99 \\
(S D=52,93)\end{array}$} \\
\hline & $\begin{array}{l}\text { Az összes } \\
\text { ábrázolt } \\
\text { társas } \\
\text { támogató } \\
\text { tényezó }\end{array}$ & & $\begin{array}{l}M=11,10 \\
(S D=5,8)\end{array}$ & \\
\hline
\end{tabular}

$\mathrm{M}=$ átlag; PRISM-D = Pictorial Representations of Illness and Self Measure rajztesztverziója; $\mathrm{SD}=$ szórás 43,2\%-a rajzolta az Énhez a betegséget közelebb, a társas támogatást pedig távolabb, ami utalhat arra, hogy a betegség okozta szenvedés, teher jelentősebb, mint a társak által nyújtott támogatás. 56,8\%-uknál azonban a társas támogatás található közelebb az Énhez, a betegség távolabb.

A teszten megjelenített, a betegséghez és a társas támogató tényezőkhöz kapcsolódó leíró statisztikák az 1 . táblázatban láthatók.

\section{A megjelenitett társas támogatás, a betegség, a depresszió- és szorongásszint kapcsolata}

Azok a személyek, akik nem jelenítették meg a PRISMD teszten a társas támogatást, szignifikánsan nagyobb mértékü állapotszorongást éltek meg $(\mathrm{M}=53,14, \mathrm{SD}=$ 15,11), mint azok a személyek, akik feltüntették bármekkora méretben a társas támogató terük tagját/tagjait $(\mathrm{M}=42,34, \mathrm{SD}=13,52)(\mathrm{t}-$ próba, $\mathrm{p}=0,040, \mathrm{df}=181)$. Továbbá azok a betegek, akik nem jelenítették meg a társas támogató tér tagjait a teszten, szignifikánsan magasabb vonásszorongás-értékkel rendelkeztek $(M=50,33$, $\mathrm{SD}=15,37)$, mint akik felrajzolták a társas támogatás valamely tagjait $(\mathrm{M}=37,85, \mathrm{SD}=10,35)$ ( $\mathrm{t}$-próba, $\mathrm{p}=$ $0,005, \mathrm{df}=153)$. Az eredmények alapján azok a személyek, akik aktuálisan nem tartották fontosnak életterükben megjeleníteni a társas támogató tér valamely tagjait (akár észlelt, akár valós hiány vagy másra fókuszáló figyelem), nagyobb szorongást tapasztaltak. A megjelenített tényezők területe, illetve a társas támogatás kategóriába sorolható körök száma azonban nem áll szignifikáns kapcsolatban a szorongásszinttel (minden p>0,05) (2. táblázat).

A társas támogatás Éntől való abszolút távolsága szignifikánsan összefügg az IPM-mel, azonban nem függ össze a depresszió- és szorongásszinttel. A t-próba eredményei alapján azok a személyek, akik az Énhez legközelebb eső, társas támogatást szimbolizáló kört az Énhez közelebb jelenítették meg, szignifikánsan kisebbnek jele-

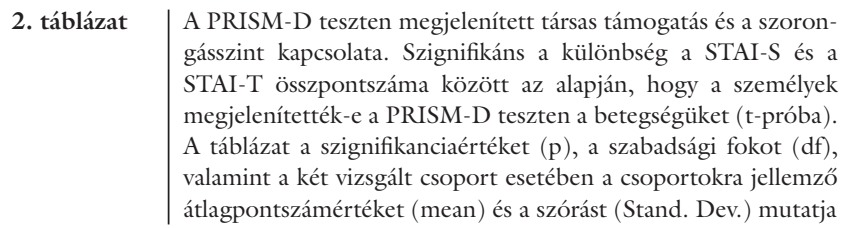

\begin{tabular}{llll}
\hline & Szignifikanciaszint & $\begin{array}{l}\text { Megjelenített } \\
\text { társas támogatást }\end{array}$ & $\begin{array}{l}\text { Nem jelenített meg } \\
\text { társas támogatást }\end{array}$ \\
\cline { 2 - 4 } & $\mathrm{p}(\mathrm{df})$ & Átlag (szórás) & Átlag (szórás) \\
\hline STAI-S & $0,040(181)$ & $42,34(13,52)$ & $53,14(15,11)$ \\
\hline STAI-T & $0,005(153)$ & $37,85(10,35)$ & $50,33(15,37)$ \\
\hline
\end{tabular}

df = szabadsági fok; $\mathrm{M}$ = átlag; $\mathrm{p}=$ szignifikanciaérték; PRISM-D = Pictorial Representations of Illness and Self Measure rajztesztverziója; SD = szórás; STAI-S = a Spielberger-féle Vonás- és Állapotszorongás Kérdőív 'állapotszorongás' alskálája; STAI-T = a Spielberger-féle Vonás- és Állapotszorongás Kérdőív 'vonásszorongás' alskálája 
nítették meg a betegségüket $(M=9,086, S D=12,28)$, mint azok, akik a legközelebbi társas támogató személyt távolabbra rajzolták $(\mathrm{M}=22,39, \mathrm{SD}=49,50)(\mathrm{p}=$ $0,047, \mathrm{df}=72,82)$. Hasonló összefüggést találtunk a megjelenített összes társas támogató tényező Éntől való átlagtávolságával kapcsolatban, bár ez esetben az összefüggés csupán tendenciaszintű volt $(\mathrm{p}=0,068)$. A fenti eredmények arra utalnak, hogy azok a személyek, akik a társas támogatást közelebb érezték magukhoz, szorosabb kapcsolatot/kapcsolatokat éltek meg, kevéssé érezték jelentősnek a betegségüket, ugyanis az IPM a nemzetközi szakirodalom alapján a betegség szubjektív megélésére és fontosságára enged következtetni [39]. Azok a személyek azonban, akik kevéssé érezték magukhoz közel a társas támogatást, feltehetőleg nagyobb jelentôséget tulajdonítottak a betegségüknek, és az vélhetően nagyobb terhet jelentett számukra.

A társas támogatás Éntôl mért abszolút távolságán túl fontos vizsgálni a társas támogatásnak a betegség viszonylatában mért relatív távolságát is, a társas támogatás és a betegség egymáshoz viszonyított helyzetét. Eredményeink szerint ugyanis azok a személyek, akik a betegséget közelebb rajzolták az Énhez, a társas támogatást pedig messzebbre, szignifikánsan magasabb depresszióértéket mutattak $(M=9,47, S D=7,08)$, mint akik a társas támogatást rajzolták az Énhez közelebb, a betegséget pedig távolabb $(\mathrm{M}=7,60, \mathrm{SD}=6,80)(\mathrm{p}=0,016$, df =91). Hasonló eredményt kaptunk az állapotszorongás-érték kapcsán $(\mathrm{p}=0,027, \mathrm{df}=142)$. Azok, akik a társas támogatást távolabb, a betegséget közelebb rajzolták az Énhez, a STAI-S skálán 45,07 pontot kaptak $(\mathrm{SD}=13,99)$, akik viszont a társas támogatást rajzolták közelebb, átlagosan 41,07 pontot kaptak (SD = 12,85). (Az adatelemzéskor a társas támogatás kategóriájába so- rolt körök közül az Ént szimbolizáló körhöz legközelebb eső kör Éntől való távolságát vettük alapul.) A fenti összefüggést demonstrálja a 2. ábra.

\section{Megbeszélés}

Kutatásunk fó célja a PRISM-D rajzteszt társas támogatás felmérésére való alkalmazhatóságának bemutatása volt. 194, súlyos kórházi fekvő beteg tesztjeit elemezve elmondható, hogy a mérőeszköz széles körü információt nyújt a páciensek szubjektíve megélt, észlelt társas támogató hálójával kapcsolatban. Mindezt egy olyan vizuális technika segítségével, mely alacsony eszközigénye, könynyen érthetősége és gyors alkalmazása miatt jól illeszkedik a klinikai környezethez [35-37]. A teszt lehetőséget ad a szakember számára akár egy viszonylag gyors elemzésre, hiszen ránézésre látható a páciens számára aktuálisan észlelt szociális háló, annak a betegséghez és az Énhez viszonyított mérete, elhelyezkedése. A rajzteszten megjelenített körök jelentését felmérő utóteszt mint kvalitatív technika pedig további információt nyújthat. A válaszokból felmérhető, hogy az aktuális élettérben megjelenített személyek mit jelentenek a páciens számára, érzelmi és/vagy instrumentális támogatást vagy éppen terhet, akadályt.

Eredményeink szerint a társas támogató tér tagjainak észlelt közelsége összefügg a betegségpercepcióval, azok a személyek ugyanis, akik a társas támogatást közelebb rajzolták az Énjükhöz, szignifikánsan kisebbre rajzolták a betegségüket (a teszten a betegség mérete a betegségpercepcióra utal). Ez az eredmény arra enged következtetni, hogy a társas támogatást önmagukhoz közelebb érzékelő páciensek kedvezőbb betegségpercepcióval rendelkeztek, mint azok a személyek, akik aktuálisan nem

\section{A/ A társas támogatás távolabb, a betegség közelebb} az Énhez

SIS: $M=6,14(S D=6,20)$, Énhez legközelebbi társas támogatás Éntől való távolsága: $\mathrm{M}=11,21(\mathrm{SD}=11,15)$, BDI: $M=9,47(S D=7,08)$, STAI-S: $M=45,07(S D=13,99)$
B / A társas támogatás közelebb, a betegség távolabb az Énhez képest

SIS: $M=15,10(S D=14,55)$, a társas támogatás Éntől való távolsága: $\mathrm{M}=7,60(\mathrm{SD}=6,80), \mathrm{BDI}: \mathrm{M}=6,27(\mathrm{SD}=5,39)$, STAI-S: $\mathrm{M}=41,07(\mathrm{SD}=12,85)$
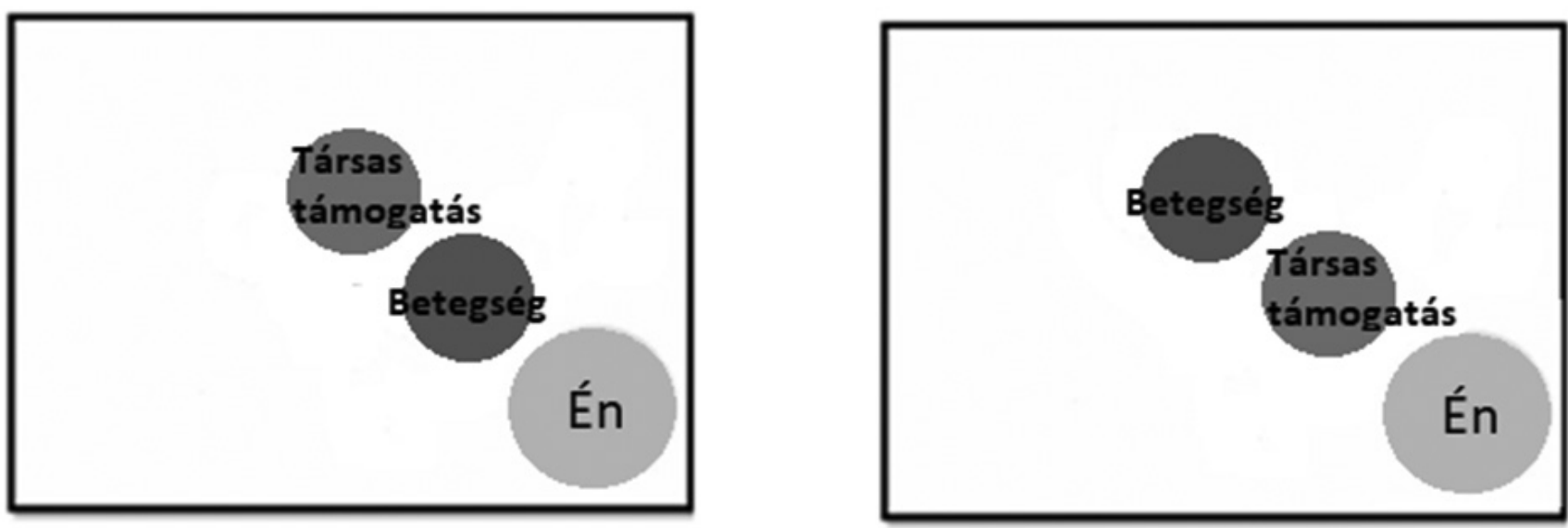

2. ábra

A társas támogatást, a betegséget és az Ént szimbolizáló kör egymáshoz való viszonyával kapcsolatos eredmény demonstrálása BDI = Beck-féle Depresszió Kérdőív; $M$ = átlag; SD = szórás; SIS = Én-betegség távolság; STAI-S = a Spielberger-féle Vonás- és Állapotszorongás Kérdőív 'állapotszorongás' alskálája 
érzik szorosan közel magukhoz táras terük tagjait. Az eredmény összecseng azokkal a szakirodalmi adatokkal, melyek szerint a társas támogatás szerepet játszik a betegségkép kialakításában $[47,48]$, ami azért is fontos, mert vizsgálati eredmények alapján a betegséggel kapcsolatos nézetek és reprezentációk pedig számos, egészséggel kapcsolatos kimenetellel függnek össze $[49,50]$. Így tehát a társas támogatás közvetve, a betegségről alakított képre gyakorolt hatásával is befolyásolhatja a páciensek egészségi mutatóit.

A társas támogató tényezőknek a betegséghez és az Énhez viszonyított térbeli elhelyezkedése pedig további értékes információt nyújthat. Vizsgálati eredményeink szerint ugyanis azok a személyek, akik a betegséget rajzolták az Ént szimbolizáló körhöz közelebb, a társas támogatást pedig távolabb, szignifikánsan nagyobb szorongást és depressziószintet éltek meg, mint akik a 'betegség' kör és az 'Én' kör közé rajzoltak legalább egy társas támogató személyt. Ez az eredményünk mintegy vizuálisan jeleníti meg a stresszpufferelmélet lényegét, mely szerint a társas támogatás azáltal fejti ki jótékony hatását, hogy képes felfogni a stresszforrástól - mely jelen esetben a betegség - érkező káros hatásokat [12].

A rajzteszt alkalmas továbbá az észlelt szociális izoláció feltárására. A korábbi PRISM+ tesztekkel [40] szemben ugyanis ezen eljárásnál minden sugalmazás nélkül, a vizsgálati személyek döntik el, hogy a betegségen kívül milyen egyéb, számukra fontos, életterükben aktuálisan jelen levő tényezőt rajzolnak be. Így mérhető az egyén számára szubjektíve észlelt izoláció, mely fontos dimenzió, eredményeink szerint ugyanis azok a páciensek, akik aktuálisan nem jelenítették meg a társas támogatást életterükben, szignifikánsan magasabb szorongásszintet mutattak. Fontos megjegyezni, hogy súlyos betegség esetén a megélt izoláció sokszor nem azt jelenti, hogy a személy számára egyáltalán nem állnak rendelkezésre társas kapcsolatok. Sok esetben a betegségból adódó lelki folyamatok - például a figyelemnek a tünetekre való fokozott beszúkülése - miatt nem képesek mobilizálni ezeket a lehetséges erőforrásokat.

Azon eredményeink, melyek szerint a társas támogatás és a paciensek szorongásszintje között kapcsolat van, összefüggnek a szakirodalmi adatokkal [13-16], ami alátámasztja, hogy ez az újszerú vizuális mérőeszköz képes kimutatni azokat az összefüggéseket, melyeket a hoszszabb, időigényesebb, a betegektől több energiaráfordítást igénylő papír-ceruza tesztek tudnak. Mivel a teszt egyszerúen és gyorsan alkalmazható, akár újra és újra felvehető, detektálhatók akár a társas támogató térben bekövetkező változások (kapcsolatok gyengülése, erősödése).

Véleményünk szerint a PRISM-D teszt jól alkalmazható az észlelt társas támogatás jelenségének mérésére. Mint vizuális eszköz könnyen és gyorsan alkalmazható akár verbálisan nehezen kommunikáló betegeknél is. A személy aktuális életterébe berajzolt, társas támogatást szimbolizáló körök azonban csupán az aktuális percepci- óról árulkodnak, a támogatás mértékéről, potenciális elérhetőségéről, valamint a támogatás tényleges igénybevételéről nem kapunk információt. Az utóteszt tisztázó kérdése (mit jelent a páciens számára az adott tényező) ezekre részben választ adhat ugyan, de a tesztnek nem célja a fenti dimenziók részletes vizsgálata.

A teszt mint projektív eljárás lehetőséget biztosít az észlelt társas támogatás szubjektív, esetlegesen kevéssé tudatos elemeinek megjelenítésére. Segíthet tudatosítani azokat a társas erőforrásokat, melyeket a páciens korábban nem vagy csak kevéssé tudott hasznosítani, ami kiindulópontja lehet a terápiás munkában annak, hogy segítsünk a páciensnek segítséget kérni és igénybe venni a társas támogatást. A terápiás munka során a pszichológus segíthet továbbá abban is, hogy a betegek felismerjék, hogy a gyógyító szakemberek és a betegtársak is potenciális támogató személyekként vannak jelen aktuális életterükben. Segíthet a velük való kommunikáció beindításában, az igények és a kérések adekvát megfogalmazásában.

A PRISM-D további előnye, hogy nem csupán a társas támogatás szubjektíve érzékelt jelenlétét tudjuk felmérni, hanem annak a betegséghez való viszonyát is, elhelyezkedését az aktuális élettéren belül. Alkalmas a szubjektíve megélt szociális izoláció, illetve a társas kapcsolatok aktivizálási nehézségének kiszűrésére. Hasznos lehet továbbá az intervenciós munka előkészítésében, információgyújtésben, a rapport kiépítésében, a terápiás munka megtervezésében vagy annak hatásának utánkövetésében is szomatikus betegek esetében.

Anyagi támogatás: A közlemény megírása, illetve a kapcsolódó kutatómunka anyagi támogatásban nem részesült.

Szerzôi munkamegosztás: S. Z.: A kutatás megtervezése, adatgyújtés, az adatok statisztikai értelmezése és a publikáció megírása. L. M.: A kutatás megtervezése, részvétel az adatgyújtésben és az eredmények értelmezésében. Cs. M. a kutatási terv kidolgozásában, az eredmények értelmezésében és a kézirat megírásában nyújtott segítséget. A cikk végleges változatát valamennyi szerző elolvasta és jóváhagyta.

Érdekeltégek: A szerzőknek nincsenek érdekeltségeik.

\section{Köszönetnyilvánítás}

Köszönetet mondunk a kutatást segítő kollégáinknak, elsősorban dr. Kovács Péternek, az adatfelvételben nyújtott segítségért.

\section{Irodalom}

[1] Kaplan BH, Cassel JC, Gore S. Social support and health. Med Care 1997; 15(5 Suppl): 47-58.

[2] Lakey B, Drew JB. A social-cognitive perspective on social support. In: Pierce GR, Lakey B, Sarason IG, et al. (eds.) Source- 
book of social support and personality. Springer, Boston, MA, 1997; pp. 107-140.

[3] Holahan CJ, Moos RH, Holahan CK, et al. Social context, coping strategies, and depressive symptoms: an expanded model with cardiac patients. J Pers Soc Psychol. 1997; 72: 918-928.

[4] Turner-Cobb JM, Gore-Felton C, Marouf F, et al. Coping, social support, and attachment style as psychosocial correlates of adjustment in men and women with HIV/AIDS. J Behav Med. 2002; 25: 337-353.

[5] Penninx BW, van Tilburg T, Boeke AJ, et al. Effects of social support and personal coping resources on depressive symptoms: different for various chronic diseases? Health Psychol. 1998; 17: 551-558.

[6] Stone AA, Mezzacappa ES, Donatone BA, et al. Psychosocial stress and social support are associated with prostate-specific antigen levels in men: results from a community screening program. Health Psychol. 1999; 18: 482-486.

[7] Goodenow C, Reisine ST, Grady KE. Quality of social support and associated social and psychological functioning in women with rheumatoid arthritis. Health Psychol. 1990; 9: 266-284.

[8] Stefaniak TJ, Dziedziul J, Walerzak AM, et al. Pain intensity and perceived social support among patients with pancreatic tumors. J Pain Relief 2012; 1: 110.

[9] Krohne HW, Slangen KE. Influence of social support on adaptation to surgery. Health Psychol. 2005; 24: 101-105.

[10] Reblin M, Uchino BN. Social and emotional support and its im plication for health. Curr Opin Psychiatry 2008; 21: 201-205.

[11] Uchino BN, Cacioppo JT, Kiecolt-Glaser JK. The relationship between social support and physiological processes: a review with emphasis on underlying mechanisms and implications for health. Psychol Bull. 1996; 119: 488-531.

[12] Cohen S, Wills TA. Stress, social support, and the buffering hypothesis. Psychol Bull. 1985; 98: 310-357.

[13] Procidano ME. The nature of perceived social support: findings of meta-analytic studies. In: Spielberger CD, Butcher JN. (eds.) Advances in personality assessment. Erlbaum, Hillsdale, NJ 1992; pp. 1-26.

[14] Sarason BR, Sarason IG, Gurung RA. Close personal relationships and health outcomes: a key to the role of social support. In: Duck S. (ed.) Handbook of personal relationships: theory, research, and interventions. John Wiley \& Sons, New York, NY 1997; pp. 547-573

[15] Lin N, Ye X, Ensel WM. Social support and depressed mood: a structural analysis. J Health Soc Behav. 1999; 40: 344-359.

[16] Lakey B, Cronin A. Low social support and major depression: research, theory and methodological issues. In: Dobson KS, Dozois DJ. (eds.) Risk factors for depression. Elsevier Academic Press, San Diego, CA, 2008; pp. 385-408.

[17] Bisschop MI, Kriegsman DM, Beekman AT, et al. Chronic diseases and depression: the modifying role of psychosocial resources. Soc Sci Med. 2004; 59: 721-733.

[18] Everson-Rose SA, Lewis TT. Psychosocial factors and cardiovascular disease. Annu Rev Public Health 2005; 26: 469-500.

[19] Patel SS, Peterson RA, Kimmel PL. The impact of social support on end-stage renal disease. Semin Dial. 2005; 18: 98-102.

[20] Molloy GJ, Johnston DW, Witham MD. Family caregiving and congestive heart failure: review and analysis. Eur J Heart Fail. 2005; 7: 592-603.

[21] Cardol M, Groenewegen PP, de Bakker DH, et al. Shared help seeking behaviour within families: a retrospective cohort study. BMJ 2005; 330: 882

[22] Brummet BH, Mark DB, Siegler IC, et al. Perceived social support as a predictor of mortality in coronary patients: effects of smoking, sedentary behaviour, and depressive symptoms. Psychosom Med. 2005; 67: 40-45.

[23] Stanton AL, Revenson TA, Tennen H. Health psychology: psy chological adjustment to chronic disease. Annu Rev Psychol. 2007; 58: 565-592.
[24] Rokach A. Correlates of loneliness as perceived by the terminally ill. Curr Psychol. 2000; 19: 237-248.

[25] Spiegel D. Mind matters - Group therapy and survival in breast cancer. N Engl J Med. 2001; 345: 1767-1768.

[26] Arpin K, Fitch M, Browne BB, et al. Prevalence and correlates of family dysfunction and poor adjustment to chronic illness in specialty clinics. J Clin Epidemiol. 1990; 43: 373-383

[27] Berkanovic E, Hurwicz ML. Rheumatoid arthritis and comorbidity. J Rheumatol. 1990; 17: 888-892.

[28] Vogt TM, Mullooly JP, Ernst D, et al. Social networks as predictors of ischemic heart disease, cancer, stroke and hypertension: incidence, survival and mortality. J Clin Epidemiol. 1992; 45: 659-666.

[29] Fitzpatrick R, Newman S, Lamb R, et al. Social relationships and psychological well-being in rheumatoid arthritis. Soc Sci Med. 1988; 27: 399-403.

[30] Cacioppo JT, Hawkley LC. Social isolation and health, with an emphasis on underlying mechanisms. Perspect Biol Med. 2003; 46(3 Suppl): S39-S52.

[31] Uchino BN. (ed.) Social support and physical health: Understanding the health consequences of our relationships. Yale University Press, New Haven, CT, 2004.

[32] Barrera M. Social support research in community psychology. In: Rappaport J, Seidman E. (eds.) Handbook of community psychology. Kluwer Academic/Plenum, New York, NY, 2000; pp. 215-245.

[33] Hartmann M, Bäzner E, Wild B, et al. Effects of interventions involving the family in the treatment of adult patients with chronic physical diseases: a meta-analysis. Psychother Psychosom. 2010; 79: 136-148.

[34] Martire LM, Schulz R, Helgeson VS, et al. Review and metaanalysis of couple-oriented interventions for chronic illness. Ann Behav Med. 2010; 40: 325-342.

[35] Havancsák R, Pócza-Véger P, Csabai M. The PRISM-D drawing test in the examination and treatment of hospital patients. In: Csabai M, Pintér JN. (eds.) Psychology in healing: Phenomenological, art psychological and body representation centered approaches. [A PRISM-D rajzteszt kórházi betegek vizsgálatában és kezelésében. In: Csabai M, Pintér JN. (szerk.) Pszichológia a gyógvításban: Fenomenológiai, múvészetpszichológiai és testkép-központú megközelítések.] Oriold és Társai Kiadó, Budapest, 2013; pp. 83-107. [Hungarian]

[36] Sándor Z, Látos M, Pócza-Véger P, et al. The drawing version of the pictorial representation of illness and self measure. Psychol Health 2020 Feb 17. Doi: 10.1080/08870446.2019.1707825. [Online ahead of print]

[37] Sándor Z, Csabai M. Application of the PRISM-D drawing test to the complex examination of cancer-related emotional and cognitive representations. [A PRISM-D rajzteszt alkalmazása a daganatos betegséggel összefüggő érzelmi és kognitív reprezentációk komplex vizsgálatára]. Orv Hetil. 2018; 159: 2021-2030. [Hungarian]

[38] Büchi S, Sensky T. PRISM: Pictorial Representation of Illness and Self Measure. A brief nonverbal measure of illness impact and therapeutic aid in psychosomatic medicine. Psychosomatics 1999; 40: 314-320.

[39] Reimus JL, Vingerhoets AJ, Soons PH, et al. Suffering in psoriasis patients: its relation with illness severity and subjective wellbeing. Int J Dermatol. 2007; 46: 1042-1045.

[40] Büchi S, Sensky T, Sharpe L, et al. Graphic representation of illness: a novel method of measuring patients' perceptions of the impact of illness. Psychother Psychosom. 1998; 67: 222-225

[41] Stefaniak TJ, Dziedziul J, Walerzak AM, et al. Pain intensity and perceived social support among patients with pancreatic tumors. J Pain Relief 2012; 1: 110. Doi: 10.4172/2167-0846.1000110.

[42] Spielberger CD, Gorsuch RL, Lushene RE. Manual for the statetrait anxiety inventory. Consulting Psychologists Press, Palo Alto, CA, 1970. 
[43] Sipos K, Sipos M. The development and validation of the Hungarian form of the STAI. In: Spielberger CD, Diaz-Guerrero R. (eds.) Cross-Cultural Anxiety. Hemisphere Publishing Corporation, Washington-London, 1978; pp. 51-61.

[44] Beck AT, Ward CH, Mendelson M, et al. An inventory for measuring depression. Arch Gen Psychiatry 1960; 4: 561-571.

[45] Richter P, Werner J, Heerlein A, et al. On the validity of the Beck Depression Inventory. A review. Psychopathology 1998; 31: 160-168.

[46] Rózsa S, Szádóczky E, Füredi J. Characteristics of the Beck De pression Scale in Hungarian Sample. [A Beck Depresszió Kérdő́iv rövidített változatának jellemzői hazai mintán.] Psychiatr Hung. 2001; 16: 384-402. [Hungarian]

[47] Guzman SJ, Nicassio PM. The contribution of negative and positive illness schemas to depression in patients with end-stage renal disease. J Behav Med. 2003; 26: 517-534.
[48] Benyamini Y, Medalion B, Garfinkel D. Patient and spouse perceptions of the patient's heart disease and their associations with received and provided social support and undermining. Psychol Health 2007; 22: 765-785.

[49] Hagger MS, Orbell S. A meta-analytic review of the commonsense model of illness representations. Psychol Health 2003; 18 : 141-184.

[50] Petrie KJ, Jago LA, Devcich DA. A role of illness perceptions in patients with medical conditions. Curr Opin Psychiatry 2007; 20: $163-167$.

(Sándor Zita,

Gyula, Tomcsányi u. 11., 5700

e-mail: sandorzita89@gmail.com)

"Sat magna usura est pro beneficio memoria." (A jóság fejében megfelelő kamat az emlékezet.)

A cikk a Creative Commons Attribution 4.0 International License (https://creativecommons.org/licenses/by/4.0/) feltételei szerint publikált Open Access közlemény, melynek szellemében a cikk bármilyen médiumban szabadon felhasználható, megosztható és újraközölhető, feltéve, hogy az eredeti szerző és a közlés helye, illetve a CC License linkje és az esetlegesen végrehajtott módosítások feltüntetésre kerülnek. (SID_1) 